\title{
HUMANITIES AND \\ SOCIAL SCIENCES
}

LATVIA

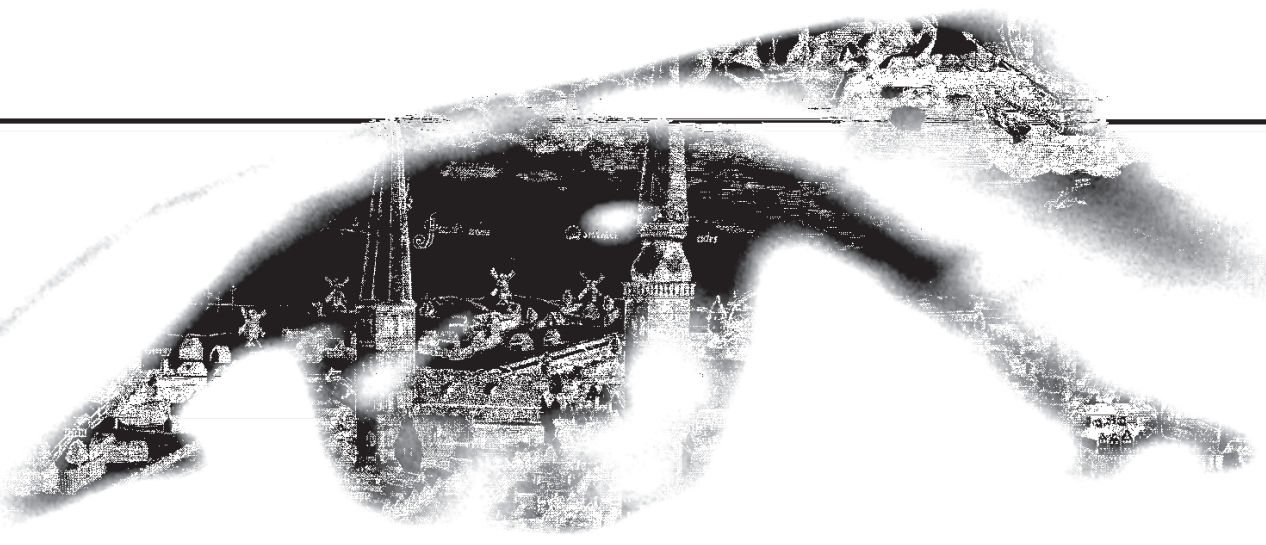

Volume 29, Issue 1

(Spring-Summer 2021)

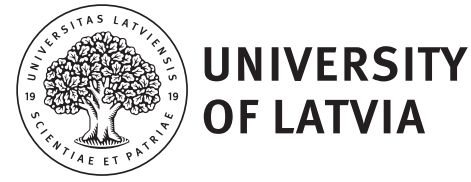




\section{HUMANITIES AND SOCIAL SCIENCES LATVIA}

Volume 29, Issue 1

(Spring-Summer 2021)

University of Latvia Press 
Journal Humanities and Social Sciences: Latvia

Volume 29, Issue 1 (Spring-Summer 2021)

Founded by the University of Latvia

Published in collaboration with:

Latvian Academy of Culture

Latvian Academy of Sciences

Latvian Association of Scientists

Latvian Writers Union

World Federation of Free Latvians

\section{Editorial Board}

Ausma Cimdina (University of Latvia)

Ainārs Dimants (Turība Business University)

Vasudha Garde (University of Pune, India)

Simon Grima (University of Malta)

Hans Jörgensen (Umeå University, Sweden)

Raita Karnìte (EPC Ltd.)

Janīna Kursīte (University of Latvia)

Boris Mattoš (University of Economics in Bratislava, Slovakia)

Arūnas Molis (Vytautas Magnus University, Lithuania)

Dali Sekhniashvili (Georgian Technical University)

Roberts Škapars (University of Latvia)

Ērika Šumilo (University of Latvia)

Aivars Tabuns (University of Latvia)

Jaak Valge (University of Tartu, Estonia)

Andrejs Veisbergs (University of Latvia)

Pēteris Zvidriṇš (University of Latvia)

\section{General Editor}

Viesturs Pauls Karnups (University of Latvia)

Layout Andra Liepiṇa

Cover design leva Krieviṇa

Correspondence and Contributions:

Manuscripts are accepted only in English

Publisher: University of Latvia Press

Aspazijas 5-132, Rīga, LV-1050, Latvia

www.apgads.lu.lv

Printed by SIA "Drukātava"

ISSN 1022-4483

(C) University of Latvia, 2021

https://doi.org/10.22364/hssl.29.1 


\section{CONTENTS}

From the Editor

Peeter Kenkmann

"No Sensational Disclosures": Foreign States and the Establishment of an Authoritarian Regime in Estonia in 1934

Ilze Medne, Kristīne Bērziṇa

Three decades of post-Soviet period: analyses of outbound tourism development patterns and environment in Latvia

Viesturs Pauls Karnups

Latvian-Norwegian Economic Relations 1918-1940

Sandra Jekabsone, Ilze Sproǵe, Solvita Kristone

The Role of Expenditure on Research and Development (R\&D)

in Promoting Economic Growth and Competitiveness

Aleksejs Jurša

Structural Analysis of Inward Foreign Direct Investment in Latvia

76

Inna Honcharuk

Energy Needs of the Agricultural Sector and the Potential

for Addressing Them

95

Nurgul Janowski

Agile Approach Versus Classical Approach in Project Management with Regard to Leadership Change 


\section{FROM THE EDITOR}

Dear Reader,

This is the first issue for 2021 and we expect to be able to publish the next issue in autumn-winter 2021.

The authors are both $\mathrm{PhD}$ students and established academics. The articles are a heterogeneous set and cover a number of fields in the humanities and social sciences such as management, economics, economic history, history, tourism and environmental studies. In this issue, we have articles by authors not only from Latvia, but also from Estonia, Germany and Ukraine.

A reminder for past and future authors that the journal can be found in the EBSCO Sociology Source Ultimate database. It would be useful for you if you ensure that your university library subscribes to this particular EBSCO database.

We hope you enjoy this issue and are looking forward to the next issue.

Best wishes

Viesturs Pauls Karnups

General Editor 
https://doi.org/10.22364/hssl.29.1.01

\title{
“NO SENSATIONAL DISCLOSURES": FOREIGN STATES AND THE ESTABLISHMENT OF AN AUTHORITARIAN REGIME IN ESTONIA IN 1934
}

\author{
Peeter Kenkmann ${ }^{1}$ \\ Institute of History and Archaeology, University of Tartu (Estonia)
}

\begin{abstract}
On 12 March 1934, the Estonian government carried out a coup d'état and justified it by the danger allegedly posed by the radical right movement, the Estonian War of Independence Veterans' League. This article examines the reports of diplomats residing in Estonia from six countries and concludes that the foreign diplomats were convinced that the real reason for the coup was the government's fear of losing power to the Veterans as a result of the forthcoming elections. Nevertheless, the coup and the subsequent establishment of an undemocratic regime did not damage Estonia's international position.
\end{abstract}

Keywords: Estonia; coup d'état; foreign relations; loss of democracy; radical right; 1930 s

\section{Introduction}

On March 12, 1934, a coup d'état was carried out in Estonia, led by Prime Minister Konstantin Päts, and with the support of the police and the military. In the process, a new political organisation that was aspiring to power - the Estonian War of Independence Veterans' League $^{2}$ - was disbanded, using the justification of ensuring public security, and an authoritarian regime was established. There was no resistance to the coup,

1 Contact Peeter Kenkmann; peeterkenkmann@gmail.com; Institute of History and Archaeology, University of Tartu, Ülikooli 18, 50090 Tartu, Estonia.

2 The Estonian War of Independence Veterans' Central League (Eesti Vabadussõjalaste Keskliit) was established in 1929, as the result of the merger of the regional organizations that stood for the social and economic interests of soldiers who had taken part in the War of Independence, 1918-1920. At the beginning of the 1930s, the movement also started to make general political demands, and persons who had not participated in the War of Independence were also able to join. The Central League was shut down by the authorities on 11 August 1933, accused of endangering public security. On 28 October 1933, the Estonian War of Independence Veterans' League (Eesti Vabadussõjalaste Liit) was established as the successor of the Central League. 
and the majority of the Estonian political elite, state officials and the media, approved of the event. ${ }^{3}$

The coup in Estonia was part of the larger process of the collapse of democracies in Europe in the interwar period. But Dirk Berg-Schlosser noted in summarising the analysis by an international research team that there is no theory providing a universal explanation for why, in some European states, democracy survived during the interwar period, but in others, it did not. ${ }^{4}$ His co-authors John D. Stephens and Gerhard Kümmel remarked that, whereas it is generally the repression of left-wing movements that is the aim of such seizures of power, then in Estonia, exceptionally, it was carried out to remove right-radicals from the political system. ${ }^{5}$ Juan J. Linz also termed the coups that occurred in Estonia and soon after in Latvia (on 15 May 1934) as unique - it was not right or left extremists or the army that destroyed democracy, but the democratically elected leaders of these countries. According to Linz, the alternative to a coup, and the resulting establishment of an authoritarian regime, would have been an undemocratic system in Estonia, where a fascist movement would play an important role. ${ }^{6}$ Similar opinion was shared by Giovanni Capoccia, as well. ${ }^{7}$

Those few foreign scholars who do mention in their research the 1934 coup in Estonia are generally not specific in describing the danger that the Veterans posed to the Estonian political system, nor do they provide reasons for calling them extreme right-wingers or fascists. Estonian researchers who have studied the League are convinced, however, that there was not much that they had in common with the Italian fascists or the German national socialists. ${ }^{8}$ Cas Mudde proffered the term "populist radical right" to describe the ideology that is common to movements like the Veterans - it is characterised by nativism, authoritarianism and populism, but also acceptance of democracy. Fascist and national socialist movements do not fit under this definition since they are more extreme. ${ }^{9}$

The general and insufficiently substantiated views of the foreign scholars, mainly political scientists, who have studied the Veterans' organisation and the reasons for the 1934 coup, can be explained by

3 See, e.g., Marandi (1991) pp. 419-475.

4 Berg-Schlosser (2002) pp. 319-323.

5 Stephens and Kümmel (2002) p. 62.

6 Linz (1978) pp. 27, 70.

7 Capoccia (2005) pp. 8-9.

8 Marandi (1991) pp. 476-498; Kasekamp (1999) pp. 65-66, 154-159; Kasekamp (2018) pp. 77, 87; Valge (2009) pp. 53-56.

9 Mudde (2007) pp. 22-23, 30-31. 
the only small number of in-depth researches in only a few languages that they were able to use in their analysis. Even less research has been done on how the coup of 1934 affected Estonia's international position. Estonia is rarely mentioned in the general studies of the history of 1930 s international relations, and the details regarding other countries' relations with Estonia are only clarified in limited research dedicated to more specific topics.

The relations of the Soviet Union, Germany, Poland and Great Britain with Estonia between the two world wars have been studied by Magnus Ilmjärv. ${ }^{10}$ The author primarily analysed the correspondence between Moscow and the Soviet Embassy in Tallinn, and, according to the author, the leadership of the Soviet Union approved of the 1934 coup in Estonia. Jaak Valge has studied the attitudes of three foreign states - Great Britain, Germany and the Soviet Union - towards the Päts coup. According to Valge, the coup did not result in any particular condemnation by the governments of these states, probably because they did not have precise information about events in Estonia, their possibilities to influence Estonian domestic politics were limited, and they had not formed close ties with the Veterans. ${ }^{11}$ Heino Arumäe, in his book on relations between Estonia and Finland in the interwar period, claims that the Finnish leadership approved of the coup. ${ }^{12}$ Of the foreign researchers, it is Russian historians Oleg Ken and Aleksandr Rupasov who have studied the relations of the Soviet Union with Estonia most comprehensively. Although Päts may have been the Soviets' preferred candidate for head of state in the 1934 elections and they understood the purpose of his coup, the researchers have not found any evidence that the Soviet Union supported him. ${ }^{13}$ Seppo Zetterberg has also analysed the events of 1934 in Estonia from a Finnish perspective to a limited extent. ${ }^{14}$

Since previous authors have studied the coup that took place in Estonia in 1934 in varied detail, and from various viewpoints, the author of this article plans to analyse, in depth, what information the foreign diplomates did hold regarding the coup of 12 March, the events leading up to the coup, and its consequences. In addition, the article assesses how the establishment of an authoritarian regime affected the relations

\footnotetext{
${ }^{10}$ Ilmjärv (2004a) pp. 84-85, 102-104. In 2010, a second revised edition of the book was published in Estonian. The references are to the latter if there were viewpoints presented there that were missing in the 2004 English language publication.

${ }^{11}$ Valge (2011) pp. 807-808; Valge (2012) pp. 60-61.

12 Arumäe (2018) p. 347.

${ }^{13}$ Ken and Rupasov (2002) pp. 240-241; Ken and Rupasov (2014) pp. 436-437, 440-441, 446-447.

14 Zetterberg (2021).
} 
Estonia had with foreign states. Six states are therefore studied, which were all important for Estonia, although for differing reasons. Firstly, Great Britain - one of the major military supporters of Estonia during the War of Independence, and from the Estonian perspective, the most valued major international power. Then there were another two democratic states with whom Estonia strove to intensify contacts - Finland and Sweden. The fourth state was Estonia's southern neighbour Latvia, which also relinquished democratic governance as a result of a 1934 coup d'état. And finally, the two dictatorships that posed the greatest security threat to Estonia - the communist Soviet Union and national socialist Germany.

The main sources for this study are the reports to their homelands sent by diplomats from the six countries who were residing in Estonia. These were preserved in the archives of the respective countries, except for the documents from the German Auswärtiges Amt, which the author of this article studied in the National Archives of the United Kingdom, where they ended up as a result of the Second World War. Unfortunately, there are materials pertaining to the diplomatic activities in Estonia between the two world wars by the countries being studied that have not so far been entirely available to researchers, or have not survived intact.

The document collection covering the anti-Estonian espionage activities of the Joint State Political Directorate under the USSR Council of People's Commissars (OGPU), is preserved in the National Archives of Estonia, where the Estonian internal political situation in 1933 and 1934 is also described.${ }^{15}$ Based on these documents, the information held by the OGPU on the events in Estonia in 1934 was limited. Due to lack of access to the relevant Russian archives, it is not possible, however, to adequately assess the actual level of knowledge held by the Soviet intelligence services on events in Estonia.

It is also difficult, based on the reports by Estonian diplomats, to clarify the attitudes of the foreign states on the 1934 coup since the documents of the Estonian embassies have only been partially preserved. According to M. Ilmjärv, after the signing of the Molotov-Ribbentrop Pact, the Estonian embassies in Moscow, Riga and Helsinki were ordered to destroy documents that could discredit the Estonian state. ${ }^{16}$ The documents of the Estonian Embassy in Berlin have also only been partially preserved. There is, however, important information in the overviews of the more important internal and foreign political events that were regularly sent to Estonian ambassadors abroad by the foreign ministry, which the ambassadors apparently used as talking points in their contacts with the governments of the foreign states.

\footnotetext{
${ }^{15}$ National Archives of Estonia (hereinafter RA) ERAF 138SM-1-54.

${ }^{16}$ Ilmjärv (2004a) p. 35.
} 
This article consists of five sections. The first section attempts to identify those people who provided information to the foreign diplomats in Estonia. In the following sections, the important stages in the Estonian domestic political crisis in 1933 and 1934 are analysed, using the reports of foreign diplomats and the positions of the Estonian foreign ministry as sources. In the last section of the article, there is an attempt to analyse whether, and how, the 1934 coup affected the relations with Estonia of the six countries under observation.

\section{The sources of information for the foreign diplomats residing in Estonia}

In order to assess the reliability of the information that was sent by the diplomats of the six states to their homelands at the end of 1933 and in 1934, the following aims to identify the circle of people with whom the diplomats had contacts during this period in Estonia. It should be noted that all the states had embassies in Tallinn except Great Britain, who had only a consulate in Tallinn.

Although the British ambassador, Sir Hughe Knatchbull-Hugessen was resident in Riga, Latvia, he usually met on his trips to Estonia the head of government and other ministers, as well as members of the diplomatic corps. The resident consul A. J. Hill mentioned in his reports numerous discussions with Estonian foreign minister Julius Seljamaa, as well as contacts with journalists and influential businessmen.

In the reports by the USSR Tallinn embassy, and the diaries of the diplomats, there are mentions of meetings with government head Päts and foreign minister Seljamaa, with numerous well-known socialists and left-wing union representatives, businessmen, public and cultural figures. In summer 1933 the Soviet embassy and the leadership of the Estonian Socialist Workers' Party (ESTP) concluded an agreement to exchange information on the Veterans. ${ }^{17}$ In August 1933 the People's Commissariat for Foreign Affairs (NKID) began requiring the embassy to make contact with the Veterans, but the ambassador Aleksei Ustinov reported to Moscow at the beginning of March 1934 that this had been unsuccessful. ${ }^{18}$ The task of collecting information on the Veterans was also allocated to the OGPU, but those Soviet spies in Estonia that are currently known to us, could

${ }^{17}$ Ilmjärv (2010) pp. 157-158.

${ }^{18}$ Stomonyakov to Antipov 15.10.1933: The Archive of the Foreign Policy of the Russian Federation (hereinafter AVPRF) 0154-26-37-2, 51-54; Ustinov to Stomonjakov 08.03.1934: AVPRF 0154-27-38-3, 29-31. 
not have provided the Soviet leadership with important information on the events covered in this article. ${ }^{19}$

German ambassador Otto Reinebeck had contacts with Päts and other members of the government, also with representatives of the local BalticGerman minority. The German embassy also received information from anonymous sources. The German ambassador was the only one who in his reports mentioned contacts with "influential members of the Veterans' movement". ${ }^{20}$ But the ambassador does not name anyone, nor is it known whether he would have received information from them regarding the events associated with the 1934 coup. Estonian historians who have studied the Veterans' movement have not found any definitive proof of their contacts with, or financing by, any German state institutions, including the National Socialist German Workers' Party (NSDAP). ${ }^{21}$ It is also stated in the collection of German foreign policy documents that "Documents that would indicate contacts between this organisation [i.e., the Veterans] and German authorities have not been found."22

Finnish ambassador Paavo Hynninen had a good opportunity for contacts with Konstantin Päts since the government head lived in the building owned by the Finnish embassy. ${ }^{23}$ Hynninen frequently mentioned Päts as a source for the information sent to Helsinki. According to Arumäe, Finnish diplomats were also generally well informed on the Estonian situation, and Hynninen was "one of us" in Estonian governmental circles. ${ }^{24}$

The Latvian ambassador Roberts Liepiṇš also stood out as being very well informed, for his objective analysis of Estonian politics and the accurate forecasting of subsequent events. In the reports sent to Riga, the diplomatic corps in Tallinn and members of the Estonian government were listed as sources, as well as anonymous sources, including persons in contact with the Veterans.

The contacts for the Swedish ambassador are difficult to ascertain since Anders Kozkul did not generally identify them in his reports, which were

\footnotetext{
${ }^{19}$ Rosenthal and Tamming (2013) pp. 63, 492-494.

${ }^{20}$ Reinebeck to the foreign ministry 02.12.1933: The National Archives (United Kingdom) (hereinafter TNA) GFM 33/3274.

${ }^{21}$ Marandi (1991) pp. 476-498; Kasekamp (1999) pp. 155-156; Arumäe (2007) p. 31; Valge (2009) pp. 53-56.

${ }^{22}$ Commentary by the compilers of the document collection that was added to the report sent by Reinebeck to the Auswärtigen Amt on 1 August 1934 (Akten zur deutschen auswärtigen Politik (1973) p. 272).

${ }^{23}$ History of the building on the website of the Finnish embassy. https://finlandabroad.fi/ web/est/saatkonnahoone (accessed on 13 January 2020).

${ }^{24}$ Arumäe (2018) p. 332.
} 
studied for the writing of this article. It seems that Swedish diplomats obtained a lot of information from the media or from journalists.

Therefore, the reports by the diplomats from the six states were mostly based on the information gleaned from the leading politicians of the parliamentary parties, higher state officials, military personnel, journalists and businessmen. Very many of these were biased as regards the Veterans - competing politicians and civil servants in the power struggle and journalists over newspaper circulation and advertising income..$^{25}$ The diplomats from the states covered here never indicated that their information on the pivotal events of the end of 1933 and 1934 had come from the Veterans, which means that the governments of the foreign states assessed the events in Estonia on the basis on information gained only from the Veterans' political opponents. For example, it was difficult for diplomats to forecast the results of the referendum and elections that took place during this period, as no public opinion polls were conducted and they could only rely on estimates from their contacts.

\section{Late 1933: the referendum}

In October 1933 a referendum took place in Estonia on the constitutional amendments initiated by the Veterans. The 1920 constitution was very liberal and parliament-centred, and there was no provision for the institution of head of state. The economic and social problems caused by the worldwide economic crisis at the start of the 1930s resulted in a deep mistrust in Estonia towards the political elite, the parties and the parliament, and the Veterans who joined the political fray at the beginning of the decade began to promote amendments to the constitution as a solution to these problems. ${ }^{26}$ According to the draft constitutional amendment that was put to referendum, the number of parliamentary seats was reduced from hundred to fifty, and the institution of a powerful head of state to essentially rule the country was to be created. The Veterans' draft was also supported by the later 1934 coup organisers Konstantin Päts and General Johan Laidoner. The referendum that took place 14-16 October 1933 resulted in

${ }^{25}$ After the Veterans joined the political fray it became clear that many of the politicians in the parliamentary parties would have missed out on a parliamentary seat in the elections scheduled for April 1934. The popularity of the Veterans' newspapers was also on the rise. The Veterans' relations with other newspapers were damaged by the former's attempts to boycott the newspapers due to their articles criticising the Veterans (Arumäe (2007) pp. 28-53; Marandi (1991) pp. 331-332, 362-363; Kasekamp (1999) pp. 62, 86).

${ }^{26}$ The reasons for changing the 1920 constitution are covered, for example, by Pajur (2018) pp. 357-371. 
a very large majority of voters supporting the constitutional amendments (73\% of those who voted, $56 \%$ of eligible citizens). After the results of the referendum were declared, the government of Jaan Tõnisson resigned and a transitional government was formed by Päts, with the main task of ensuring the implementation of the constitutional changes. ${ }^{27}$

Before the referendum, the ambassadors of the countries studied here were concerned about the possible results of the referendum and a possible coup attempt by the Veterans if the referendum fails. Such fears were caused by a very tense campaign organised by both the supporters and opponents of the constitutional amendments and attempts by the authorities to take administrative measures to prevent the Veterans' draft from winning. ${ }^{28}$ However, researchers have not yet found any proof of a coup planned by the Veterans at the end of 1933. After the referendum, the British, German, Latvian and Finnish ambassadors stated in their reports that the domestic political tension in Estonia had decreased. The Veterans were accused of ties to the German National Socialists by their opponents, but the British and German ambassadors did not consider it possible for historical reasons, and the Latvian ambassador also described the Veterans as a national movement. ${ }^{29}$ The Soviets were the most pessimistic. According to the assessment of the USSR NKID, the "fascismization" of Estonia would take place in any case, but should the referendum fail, a coup attempt by the Veterans could not be excluded. The diaries of the diplomats in the Tallinn embassy show that the information discrediting the Veterans was mostly provided to the Soviets by Estonian socialists - the fiercest political opponents of the Veterans. ${ }^{30}$

During this period, Estonian ambassadors in London, Moscow and Stockholm tried to calm down the governments of the respective countries

27 See, e.g., Pajur (2005) pp. 86-90.

${ }^{28}$ Marandi (1991) pp. 230-239.

${ }^{29}$ Knatchbull-Hugessen to Simon 11.11.1933: TNA FO 371/17184; Reinebeck to the foreign ministry 24.10.1933, 02.12.1933, 07.12.1933: TNA GFM 33/3274, TNA GFM 33/3486; Liepiṇš to Salnais 17.10.1933: The Latvian State Historical Archives (hereinafter LVVA) 1303-1-10828, 517-525; Liepiṇš to Salnais 05.12.1933: LVVA 2575-8-35, 61-67; Hynninen to the foreign ministry 30.09.1933, 17.10.1933: The Archives of the Ministry for Foreign Affairs of Finland (hereinafter UM) 5 C 12, Viro; Swedish embassy in Tallinn to B.Ö. Unden 27.09.1933: The National Archives of Sweden (hereinafter SRA) 230032.1, F 1:4, HP 1 (Ee), 1933-1934. "Historical reasons" here refers to the national memory of the centuries-long and substantial role of the German elite in governing the Estonian territory that ended with the founding of the Republic of Estonia.

${ }^{30}$ Stomonyakov to Antipov 15.10.1933: AVPRF 0154-26-37-2, 51-54; Antipov's and Klyavin's diaries $09.08 .1933,15.08 .1933,20.09 .1933,04.10 .1933,12.10 .1933$, 22.10.1933, 26.10.1933, 28.10.1933: AVPRF 0154-26-37-5, 153-155, 170, 175-176, 200-201, 208, 219-222. 
and denied rumours about Estonia's domestic political instability and the threat posed by the Veterans. ${ }^{31}$ The Estonian foreign ministry also denied that the Veterans had coup intentions and referred to the lack of information about their ties with national socialists. ${ }^{32}$ The neutral position of the ministry at that time could be explained by the fact that the Veterans had not yet announced their intention to join the election campaign, and that their plan to amend the constitution was also supported by a part of the current political elite.

\section{Early 1934: the election campaign}

The amended constitution entered into force on 24 January 1934, and during the subsequent one hundred days, elections for a powerful head of state and a smaller parliament were to take place. The main attention was naturally concentrated on the elections for head of state, where four candidates had been nominated: by the Veterans - their official leader retired General Andres Larka, by the Farmers' Party - Konstantin Päts, the head of the transitional government, by the election committee that was based on the Settlers' Party - retired General Johan Laidoner, commander-in-chief of the armed forces during the War of Independence, and by the ESTP - their leader August Rei. Prior to the nomination of the candidates, there was a brief, fruitless testing of the waters between Päts and the Veterans, aimed at gaining Veterans' support for his candidature. ${ }^{33}$ More serious, but just as fruitless were the negotiations held with the Veterans by Laidoner. Not supporting Päts or Laidoner as a candidate has been called the Veterans' fatal mistake. ${ }^{34}$ The number of signatures required to support the head of state nomination does not indicate the actual popularity of the candidates, but Larka's overwhelming support ${ }^{35}$ could have alarmed Päts and Laidoner in that the Veterans' candidate could gain the absolute majority needed to win in the first round.

${ }^{31}$ Kallas to the foreign ministry 19.09.1933: RA ERA 957-13-743, 50-51; Tofer to the foreign ministry $06.09 .1933,25.10 .1933$, Kirotar to the foreign ministry 04.12 .1933 : RA ERA 957-13-532, 54-55, 94-95, 102-104; Akel to the foreign ministry 15.08.1933: RA ERA 957-13-749, 10.

32 Estonian foreign ministry's political overviews August-October 1933: RA ERA 975-13767, 31-32; RA ERA 957-13-769, 15, 19-19p, 36, 66-67.

${ }^{33}$ Information about these negotiations reached even the ears of Soviet diplomats Antipov to Stomonyakov 29.01.1934: AVPRF 0154-27-38-3, 2-4.

${ }^{34}$ Marandi (1991) pp. 376-382; Kasekamp (1999) p. 55.

35 The requirement was 10,000 signatures, but by 11 March Larka had collected 52,436, Laidoner 18,220, Päts 8,969 and Rei 2,786 (Valge (2019) p. 434). 
None of the diplomats of the six countries could predict the winner of the elections. The Latvian ambassador, in his 7 December 1933 report, expressed opinion that in the case of Larka's victory, the future would be unpredictable. If Laidoner wins, Estonia could strengthen relations with Poland. Liepinš nevertheless hoped that foreign policy would remain in the hands of professional diplomats and that major changes would not take place in this field. ${ }^{36}$ According to the assessments by the Finnish ambassador in January 1934, no candidate would achieve the necessary majority to win in the first round, and that in the second round General Larka would compete against either Päts or Laidoner. ${ }^{37}$ The Swedish ambassador, whose information was based on newspapers, predicted that most likely there would not be a clear winner in the first round of the elections, whereas in the second round Päts would have the best chance since he could also have the support of the Veterans, who opposed Laidoner. Kozkul also drew attention to the Veterans' aggressive election campaign which was not directed at promoting a clear political program, but at attacking the opponents. ${ }^{38}$

According to the diaries and reports of the USSR diplomats, contradictory opinions were sent to Moscow in the end of 1933 and beginning of 1934 on the winner of the elections. Apparently, it depended on which contacts the diplomats had happened to have. Among prominent Estonians the most likely winner of the elections was Päts, who was also considered as the most suitable candidate for the Soviets. ${ }^{39}$ At the same time the Soviet embassy did not have a clear understanding of how the coming to power of the Veterans could affect Estonian relations with Moscow. On March 8, Soviet diplomats reported to Moscow on rumours about a coup d'état planned by Päts. ${ }^{40}$

The British ambassador refrained from predicting the election results in his report of 1 March, because "it is unnecessary to weary you with a forecast of chances of the four presidential candidates." Although it had been claimed in previous numerous embassy reports that national socialist activities were not a serious threat in Estonia, the ambassador wrote

${ }^{36}$ Liepiṇš to Salnais 07.12.1933: LVVA 2575-8-35, 68-76.

${ }^{37}$ Hynninen to the foreign ministry 18.01.1934, 26.01.1934: UM 5 C 12, Viro.

${ }^{38}$ Kozkul to Sandler 01.03.1934: SRA 230032.1, F 1:4, HP 1 (Ee), 1933-1934.

${ }^{39}$ Diaries of Klyavin and Antipov 02-03.11.1933, 07.11.1933, 10.11.1933, 22.11.1933, 23.11.1933, 04.12.1933: AVPRF 0154-26-37-5, 188, 194, 198, 211, 225, 231, 234-235, 240-241, 257; Antipov to Stomonyakov 09.01.1934, 20.02.1934, 08.03.1934: AVPRF 0154-27-38-3, 10-11, 13-14, 29-31.

${ }^{40}$ Ustinov's diary 19.02.1934: AVPRF 0154-27-39-7, 5; Ustinov to Stomonyakov 07.03.1934, 08.03.1934: AVPRF 0154-27-38-3, 21-23, 29-31; Antipov to Stomonyakov 08.03.1934: AVPRF, 05-14-102-109, 24-25. 
to London on 1 March that a number of official sources had confirmed the covert financing of the Veterans' campaign by the national socialists. Päts promised the ambassador that he would end the Veterans' activities as soon as he had sufficient facts and power. ${ }^{41}$

\section{March: the coup d'état}

On 12 March 1934, the government led by Konstantin Päts declared a six-month state of emergency in Estonia, appointed General Laidoner commander-in-chief of the armed forces, shut down the Estonian War of Independence Veterans' League, and arrested several hundred leading Veterans. There was no resistance to the coup. ${ }^{42} \mathrm{~A}$ parliamentary session took place on 15 March, where Päts justified his actions with the planned seizure of power by the Veterans, the subsequent risk of civil war and external danger, and referred to the people's "serious illness", who had thereby lost the right to participate in deciding matters of state. On 16 March, the parliament approved the establishment of a state of emergency. ${ }^{43}$ On 19 March, Päts postponed, until the end of the state of emergency, the elections for the head of state and parliament that were to be held in April. The authorities began to restrict the freedoms of speech and assembly, the activities of all parties were halted, and media censorship was established. A subsequent investigation found no evidence of the Veterans having plotted a coup. ${ }^{44}$

On 7 September Päts extended the state of emergency by one year, which meant that the elections were once again postponed and that the authoritarian regime continued. An extraordinary parliamentary session took place from 28 September to 2 October, which Päts demanded be cut short since a number of parliamentarians began criticising government policies. In the subsequent years Päts governed without a parliament, using decree legislation that was foreseen for the head of state, in the case

${ }^{41}$ Knatchbull-Hugessen to Simon 13.01.1934: TNA FO 371/18230; 24.01.1934: TNA FO 419/28; 30.01.1934, 01.03.1934: TNA FO 371/18236.

${ }^{42}$ As of February 1934, the Veterans began receiving hints from their supporters who worked in state institutions regarding Päts's intentions, but the movement's leaders decided not to react. They believed that since they could not be accused of anything, any repression carried out by the authorities would be short term and would be good publicity for the Veterans. Päts, however, knew that the Veterans had decided not to resist (Marandi (1991) pp. 412-414; Kasekamp (1999) pp. 100-101).

${ }^{43}$ Riigikogu V koosseis (1934) pp. 1435-1438, 1459.

${ }^{44}$ During the court session that took place on 12-20 June 1935, thirty-seven Veterans were only found guilty of organizing a bitter political fight that endangered public security, and were given short suspended prison sentences: RA ERA 927-2-4, 432-435. 
of "urgent state necessity", in the constitutional amendments that were approved by the referendum in October 1933.

The British embassy informed London of the establishment of a state of emergency in Estonia on 13 March. The report notes that according to the media the Veterans planned a putsch. On 16 March the consul A. J. Hill described the speech that Päts had given on the previous day in the parliament as disappointing, since Päts made no sensational disclosures. The Estonian ambassador in London, Oskar Kallas, visited the Foreign Office's head of the Scandinavian and Baltic States department, Lawrence Collier, on 13 and 16 March, and in Kallas's assessment, Collier was satisfied with the actions of the Estonian government. ${ }^{45}$

During the following months, Estonian politicians and diplomats repeatedly assured British diplomats that the restoration of democracy was the ultimate goal of Päts's government, but that it would take more time to achieve this. The Britons concluded from this that the Estonian government wished to preserve the dictatorial powers that they held and would not risk elections since they were unsure of a favourable electoral result. In the 1934 annual report by the British embassy in Riga, the Estonian system of state is described as a "virtual dictatorship", and it was claimed that the reason for the coup d'état was Päts's fear of losing the elections to Larka. ${ }^{46}$

The immediate reaction by the USSR NKID and its Tallinn embassy to the coup is unknown due to the lack of archival documents. The Estonian ambassador in Moscow, Karl Tofer, referred in his 15 March report to an article published in Pravda, the organ of the All-Union Communist (Bolshevik) Party (VKP(b)), according to which the coming to power of the fascists, i.e., Veterans, could have presented a threat to Estonian independence. In Tofer's opinion this was an accurate description of the view held by "Moscow official circles". ${ }^{47}$

In the subsequent correspondence between the NKID and the Tallinn embassy, the defeat of the Veterans was deemed to be positive from the standpoint of Soviet and Estonian relations. At the same time, the ambassador A. Ustinov called the new regime in Estonia the "dictatorship of Päts and Laidoner" and stated that there was a generally accepted opinion that Päts would agree to holding presidential elections only if he was sure he could win. The extraordinary session of the parliament at the end of

\footnotetext{
${ }^{45}$ Knatchbull-Hugessen to Simon 13.03.1934, 22.03.1934: TNA FO 371/18236; Kallas to the foreign minister 17.03.1934: RA ERA 1583-2-3, 100.

${ }^{46}$ Knatchbull-Hugessen to Simon 23.03.1934, 31.08.1934: TNA FO 371/18236; Torr to Simon 30.01.1935: TNA FO 371/19400.

${ }^{47}$ Tofer to the foreign ministry 20.03.1934: RA ERA 957-13-532, 133-135.
} 
September, beginning of October, was described by Ustinov as a comedy played out to justify Päts's government's actions. ${ }^{48}$

According to the report sent by the German ambassador on 15 March to Berlin, the Veterans were not planning an armed uprising and the real reason for Päts's actions were the good prospects for the Veterans in the coming elections. On 20 March Reinebeck informed Berlin of Päts's decision to postpone the elections and doubted that democracy would soon be reinstated in Estonia. In his 23 April and subsequent reports, he called the Estonian government the "Diktaturregierung Päts-Laidoner". In the autumn, Päts spoke to the German ambassador of the need to amend the new constitution and claimed that the government's course would not change until the reform had been implemented. ${ }^{49}$

The Latvian ambassador, in his report sent to Riga on 13 March, also doubted the explanations of the Estonian authorities. In R. Liepiňšs's opinion, the Veterans would only have had reason for a coup if they had not succeeded in the elections. ${ }^{50}$ In his subsequent reports Liepiṇs repeatedly called the system of government in Estonia the "Päts-Laidoner dictatorship". He did not believe that Estonia would revert in the near future to a parliamentary system - it was more likely that yet another amendment of the constitution would take place. ${ }^{51}$

Estonian foreign minister J. Seljamaa left on 15 March on a visit to Finland, during the course of which he met with the Finnish president and other leading statesmen. In his research, H. Arumäe concluded, based on the memos written in both the Estonian and Finnish foreign ministries, that Finnish politicians in general approved of the actions by the Estonian government. ${ }^{52}$ However, the Finnish ambassador, P. Hynninen, reported to Helsinki after the coup that although Päts received praise from all the parliamentarians on 15 March, he made no sensational disclosures regarding the Veterans, and that there was apparently no basis for the stories that the Veterans were plotting a coup. In the following

\footnotetext{
${ }^{48}$ Stomonyakov to Ustinov 25.03.1934: AVRRF 0154- 27-26-2, 34; Ustinov to Stomonyakov 28.03.1934: AVPRF 0154-26-37-2, 20-22; 08.05.2020: AVPRF 0154-27-38-3, 64-65; Ustinov to Litvinov 17.10.1934: AVRRF 0154-27-38-3, 56.

${ }^{49}$ Reinebeck to the foreign ministry $15.03 .1934,20.03 .1934,23.04 .1934,18.05 .1934$, 12.09.1834: TNA GFM 33/3274.

${ }^{50}$ Liepiṇš to Munters 13.03.1934: LVVA 1303-1-10828, 595-603.

${ }^{51}$ Liepiṇš to Ulmanis 17.04.1934, 18.04.1934: LVVA 2575-8-36, 406-413p, 414-429p; 11.10.1934: LVVA 2575-8-37, 63-74p.

${ }^{52}$ Arumäe (2018) pp. 346-347.
} 
reports, the ambassador referred to dictatorial rule in Estonia and noted that the restoration of democracy may prove to be complicated..$^{53}$

In his reports sent to Stockholm, the Swedish ambassador described the explanations given in the Estonian media regarding the threats posed by the Veterans, for which, in his words, the Estonian government did not present any confirming evidence. All the parties supported Päts's actions, and the newspapers voiced their approval. A. Kozkul opined that the elections would be postponed indefinitely. ${ }^{54}$

The domestic and foreign policy overviews compiled by the Estonian foreign ministry for the Estonian diplomats abroad were in accordance, after 12 March, with the government's rhetoric and, based on what is currently known to researchers, were largely untrue. In the 20 March overview, the Veterans organisation was described as being similar to the German national socialists, Italian fascists and Soviet Bolsheviks. The Veterans had supposedly been ordered to infiltrate state institutions and to be prepared for armed response. The overviews did not directly mention coup intentions by the Veterans, but claimed that the government needed to intervene in order to avoid an outbreak of conflict in the future. In the overview of 5 October, the entire blame for halting the parliamentary extraordinary session lay with the opposition, whose criticism of the government was said to be unfounded. ${ }^{55}$

\section{Foreign countries' relations with Estonia after the coup d'état}

The 1934 coup d'état and the establishment of an authoritarian regime did not result in substantial changes in the attitudes of foreign states towards Estonia. This is evident both from the reports of contemporary diplomats and from the findings of later researchers. There were several reasons for this.

Firstly, the establishment of an authoritarian regime in interwar Europe was nothing out of the ordinary, and according to Carr, alliances between democratic states and states who had relinquished democracy were often formed not because of ideological proximity, but based on common interest. ${ }^{56}$ Relinquishing democracy could also be seen as the only solution to the social and political problems caused by the worldwide economic crisis at the beginning of the 1930s, especially in states which did not

\footnotetext{
${ }^{53}$ Hynninen to the foreign ministry 19.03.1934, 15.05.1934, 03.10.1934, 23.10 1934: UM 5 C 12, 1934.

${ }^{54}$ Kozkul to Sandler 14.03.1934, 17.03.1934: SRA 230032.1, F 1:4, HP 1 (Ee), 1933-1934.

${ }^{55}$ RA ERA 957-13-769, 96-99; RA ERA 1583-2-4, 302-305.

${ }^{56}$ Carr (1947) pp. 262-263.
} 
have a tradition of longstanding political stability. ${ }^{57}$ In addition, during that period in Europe, there was a varied understanding of democracy, and democracy with complete electoral and citizen rights was in any case a very new phenomenon. ${ }^{58}$ Relations between Estonia and other countries after the coup d'état should be examined from this perspective.

Secondly, Estonia's international position was supported by the fact that a significant section of the existing political elite, including Konstantin Päts and General Laidoner who were amongst the best recognised Estonian statesmen, maintained its power as a result of the coup, and that it claimed that the rise to power of a political movement with ties to the German National Socialists, and a desire for dictatorship, had been avoided. After the coup, the foreign policy decision-making became the monopoly of a small group of people. ${ }^{59}$

Thirdly, those states whose positions are being examined in this paper were not necessarily even interested in deeper political relations with Estonia, beyond the usual diplomatic communication. Or the Estonian system of government was not important enough for them that its change would have led to a reassessment of foreign policy towards Estonia. That does not mean, however, that these states did not have strategic interests regarding Estonia.

Before the coup, Soviet diplomats directly stated that they considered K. Päts to be the most suitable candidate for the post of the head of state amongst the existing candidates. ${ }^{60}$ But as M. Ilmjärv notes, although the 12 March coup d'état was subsequently approved in Moscow, the Soviets became quickly disappointed with Päts's politics, especially because he was unable or unwilling to get rid of General Laidoner, who was very ambitious in directing Estonia's foreign relations, but was considered an anglophile and polonophile. ${ }^{61}$ During the period under observation in this article, the Central Committee Politburo of the VKP(b), the highest policy-making authority of the party, rarely discussed topics associated with Estonia, and the measures and allocated funds to directly influence Estonia were insufficient, even from Moscow's viewpoint. After the 1934 coup, the Politburo made no decisions due to the changed Estonian domestic political situation. ${ }^{62}$

\footnotetext{
${ }^{57}$ Marks (2003) p. 139.

${ }^{58}$ Buchanan (2002) pp. 44, 47.

${ }^{59}$ Ilmjärv (2004a) p. 544.

${ }^{60}$ Klyavin's diary 04.12.1933: AVPRF 0154-26-37-5, 257.

${ }^{61}$ Ilmjärv (2004a) p. 103.

${ }^{62}$ Ken and Rupasov (2014) pp. 424-426, 433-440, 446-447, 449-451, 470-474; Valge (2011) pp. 798-799.
} 
Like Soviet diplomats, the German ambassador O. Reinebeck also predicted immediately after the coup, on 20 March, that it would have a positive effect on Estonian-Soviet relations. But according to the 1935 report by Germany's Tallinn embassy, relations between Estonia and the Soviet Union had cooled somewhat. Great Britain's embassy also claimed in their 1935 report that relations between Estonia and the Soviet Union were friendly but limited. ${ }^{63}$

The main rival to the Soviet Union as regards influence over Estonia was Germany. After rising to power, Hitler's aim was to achieve free reign in the eastern part of the European continent in order to resolve the German Lebensraum problem, and to achieve this primarily through agreements with the major powers that were dominant in European politics. ${ }^{64}$ Compared to this, Estonia's internal developments were of secondary importance. Although there are claims in some studies published in Estonia that in summer 1935 foreign policy in Estonia began to develop with an orientation towards Germany, there are few justifications for this claim, with intelligence cooperation directed against the Soviet Union as an exception. ${ }^{65}$

The 1935 and 1936 reports by the German embassy in Tallinn note positive developments in Estonia-Germany relations, both in economic and political fields, and referred to the increase in German influence in the region after the naval agreement concluded with Great Britain on 18 June $1935 .{ }^{66}$ Nevertheless, there is no basis to conclude that Estonia's foreign policy was completely German-oriented. ${ }^{67}$ The annual reports show that the German embassy in Tallinn was aware of the loss of democracy and the repression of the opposition, including the Veterans, by the authorities, but that there were no consequences to relations between the two countries. Later, the embassy began to praise the effectiveness of the authoritarian regime in Estonia. The then German ambassador to Tallinn, Hans Frohwein wrote in April 1938: "The authoritarian regime, with no parliament, that was established by a coup in 1934, and which has lasted until today, has been of great service to the state." 68

${ }^{63}$ Reinebeck to the foreign ministry 20.03.1934: TNA GFM 33/3274 and 10.01.1936: TNA GFM 33/2547; Torr to Eden 10.02.1936: TNA FO 371/20311.

${ }^{64}$ Schmidt (2002) pp. 117-120, 155-158.

${ }^{65}$ Ilmjärv (2004a) pp. 190-194; Ilmjärv (2004b) pp. 63-65, 70-73.

${ }^{66}$ Reinebeck to the foreign ministry 10.01.1936, Frohwein to the foreign ministry 26.01.1937: TNA GFM 33/2547.

${ }^{67}$ British diplomats in Estonia, for example, did not reach such a conclusion, according to the embassy's 1935 report - Torr to Eden 10.02.1936: TNA FO 371/20311.

${ }^{68}$ Frohwein to the foreign ministry 29.04.1938: TNA GFM 33/673. 
The most obvious proof of the lack of interest by Great Britain towards Estonia is that relations with Estonia are hardly mentioned in the British general foreign policy studies, either before or after the 1934 coup. ${ }^{69} \mathrm{Sir}$ Hughe Knatchbull-Hugessen, who served as ambassador for the Baltic states in 1930-1934, was essentially silent in his memoirs regarding the political interests of Great Britain towards the Baltic states. ${ }^{70}$ As mentioned earlier, Knatchbull-Hugessen did not even bother to analyse for the Foreign Office different candidates' prospects in the run-up to the April 1934 elections. $^{71}$

In the 1934 and 1935 reports by the British embassy in Riga, it was only economic matters that were noted as an important topic in the relations between Great Britain and Estonia. ${ }^{72}$ The same was also noted regarding British-Estonian relations by Germany's Tallinn embassy in its 1935 and 1936 reports. ${ }^{73}$ In their reports on Estonian politics in 1935-1937, British diplomats often assessed Estonia's domestic political developments from the perspective of how this would affect the popularity of the Veterans, whom they also called fascists and Nazi supporters. ${ }^{74}$ Like the Germans, the Britons also found positive sides to Päts's rule. The War Office's "historical sketch" written around October 1938, said that in Estonia "the period of authoritarian government was marked on the whole by an improvement in the internal condition." 75 The lack of interest by Great Britain regarding political topics associated with Estonia, and the focus on economic relations, is also emphasised in thematic research. ${ }^{76}$

According to the works covering Latvian general history that have been published after the restoration of independence, Latvia pursued the intensification of cooperation between the Baltic states in the first half of the 1920s, but the only result of this was a cooperation agreement with Estonia in 1923. The changes that occurred in the first half of the 1930s in the politics of European states, especially Hitler's coming

${ }^{69}$ See, e.g., Lee (1996); Pearce and Stewart (1996).

${ }^{70}$ Knatchbull-Hugessen (1949) pp. 60-71.

${ }^{71}$ Knatchbull-Hugessen to Simon 01.03.1934: TNA FO 371/18236.

${ }^{72}$ Torr to Simon 30.01.1935: TNA FO 371/19400; Torr to Eden 10.02.1936: TNA FO 371/20311.

${ }^{73}$ Reinebeck to the foreign ministry 10.01 .1936 , Frohwein to the foreign ministry 26.01.1937: TNA, GFM 33/2547.

${ }^{74}$ In the summer of 1935, a new British consul, W. H. Gallienne, arrived in Estonia, who had not witnessed the coup of 1934 by himself. His analysis of the domestic political situation in Estonia was usually quite understanding of Päts's politics (Kenkmann (2013) pp. 79-82).

${ }^{75}$ Frohwein to the foreign ministry 29.04.1938: TNA GFM 33/673; TNA WO 106/5143.

${ }^{76}$ E.g., Hinkkanen-Lievonen (1986) pp. 37-39, 43; Salmon (1988) pp. 114-115; Powell (2003) p. 194. 
to power in Germany, reinvigorated the need for cooperation between the Baltic states. ${ }^{77}$ In the agreement signed on 17 February 1934 in Riga, Latvia intensified its relations with Estonia, and on 12 September 1934 the so-called Baltic Entente agreement was signed in Geneva, on foreign policy cooperation between Estonia, Latvia and Lithuania. ${ }^{78}$ The authors of the works referred to in this paragraph do not note any differences between the foreign policies of democratic and authoritarian Latvia (and Estonia).

In spring 1934, Päts was considered by the Latvian embassy in Tallinn as the most suitable candidate for the post of head of state. ${ }^{79}$ Although Latvia was Estonia's most important interwar foreign policy partner, the relations between the states did not develop as far as was hoped. In the 1935 report by the British embassy in Riga, it is noted that the cooperation between Estonia and Latvia leaves something to be desired, and in the 1938 report it is said that the cooperation between the Baltic states weakens year by year. ${ }^{80}$

Finland, on one hand, had already committed in the 1920s to cooperation primarily with the Scandinavian states in order to ensure its security, which resulted in avoiding closer ties with Estonia and the other Baltic states. ${ }^{81}$ On the other hand, both before and after the 1934 coup, annual unofficial meetings were taking place between the Estonian and Finnish heads of state, and the Finnish president Pehr Evind Svinhufvud also visited Estonia in August 1934. Nevertheless, certain tensions in Estonian-Finnish relations arose after 1934. The Estonian leadership was dissatisfied with criticism of Finnish newspapers about the Estonian authoritarian regime and Finnish politicians were unsuccessfully waiting for the restoration of democracy in Estonia. ${ }^{82}$ Military and intelligence cooperation between Finland and Estonia against the Soviet Union also took place secretly throughout the interwar period. This cooperation was not affected by the coup d'état of 12 March and the subsequent changes in the leadership of the Estonian army. ${ }^{83}$

The 1936 report by the German embassy in Tallinn notes that although the Estonian-Finnish relations were good, the hope held by the Estonian

${ }^{77}$ Duhanovs, Feldmanis and Stranga (1994) pp. 8-12, 24-26; Bleiere et al. (2014) pp. 178-85.

${ }^{78}$ Arumäe (2018) pp. 376-382.

${ }^{79}$ Liepiṇš to Munters 17.04.1934: LVVA 2575-8-36, 414-429p.

${ }^{80}$ Torr to Eden 10.02.1936: TNA FO 371/20311; Torr to Eden 07.01.1939: TNA FO $371 / 23605$.

${ }^{81}$ Turtola (1988) p. 108; Arumäe (2018) pp. 383-384.

${ }^{82}$ Zetterberg (2021) pp. 128-133, 135-137, 150-153.

${ }^{83}$ Leskinen (2000) pp. 198-202. 
government for closer political cooperation was not fulfilled since Finland primarily wanted closer ties with the Scandinavian states. The same was said in the report on Estonia's relations with Sweden. ${ }^{84}$

The Finnish attitude to Estonia was strongly dependent on Swedish foreign policy. The motive of the latter in limiting contacts with the Baltic states was a fear regarding the proximity of the Soviet Union - since Sweden considered their independence to be insecure and temporary, it avoided concluding closer political ties with the Baltic states or taking political responsibilities. Sweden even considered Finland's active contribution to cooperation with Estonia and the other Baltic states as dangerous. At the beginning of the 1930s, the Baltic states and Sweden retreated even further politically from each other since social democrats dominated in Swedish politics, but in all the Baltic states there were authoritarian regimes in power. But the coup in Estonia was not the reason for the lack of close political relations with Sweden. ${ }^{85}$

\section{Conclusion}

In this study, there is an analysis of the assessments provided by diplomats from Great Britain, Sweden, Finland, Latvia, Germany and the Soviet Union of the coup d'état that took place on 12 March 1934 in Estonia. The initiator of the events being studied was the Veterans movement which became a political pressure group at the beginning of the 1930s. After the referendum that took place in October 1933, where the draft constitutional amendments that had been produced by them were overwhelmingly approved, the Veterans decided to also present their own candidates for the elections for head of state and parliament that were to take place in April 1934. The increase in popularity of the Veterans, and their rhetoric against the current political establishment, endangered the parliamentary parties, and the positions held by the officials, military and media who were associated with the parties. In the course of the coup, the Estonian War of Independence Veterans' League was banned and the elections postponed.

The reports by the foreign diplomats residing in Estonia, written with different frequency and a varying degree of detail, show that they had contacts mainly with the leading politicians of the parliamentary parties, state officials, senior officers, businessmen and journalists, of whom many were critical of the Veterans. The information on them sent

\footnotetext{
${ }^{84}$ Frohwein to the foreign ministry 26.01.1937: TNA GFM 33/2547.

${ }^{85}$ See, e.g., Carlgren (1995) pp. 14-19, 24-26; Jaanson (2001) pp. 273-274; Kuldkepp (2016) pp. 415-416; Trencsényi et al. (2018) p. 51 on this subject.
} 
by the diplomats to their capitals, therefore, was biased and conflicting, which increased the lack of awareness regarding the Veterans' ideology and political goals.

Prior to the referendum, in the autumn of 1933, and influenced by a tense election campaign, the foreign diplomats were concerned about the internal security of Estonia and negative in their description of the Veterans. After the clear win in the referendum, however, a reduction in tensions in society was noted. Although at the end of 1933 there was much speculation about the Veterans' contacts with Germany and the NSDAP, the foreign diplomats remarked in their reports as to the lack of respective proof, and also referred to the Estonians' historic anti-German attitudes, which would have made it difficult for the Veterans to explain such cooperation to the Estonian public.

The relatively neutral attitude towards the Veterans at the end of 1933 and the beginning of 1934 of Estonian politicians and public figures who were sharing information with foreign diplomats, can be explained by the lack of clarity regarding the political ambitions of the Veterans. At the same time negotiations were being held, and were failing, with Päts and General Laidoner on whether the Veterans would support one or the other in the coming elections. As the election campaign gathered steam the Estonian politicians and officials began to hint at the government's intention to get rid of the Veterans, and the foreign ministry's political overviews for Estonian ambassadors abroad in 1934 and especially after the 12 March coup became more critical of the Veterans. Diplomats from differing foreign states considered Päts to be the most suitable candidate for their homelands for the position of head of state with extensive powers, more than the head of the Veterans, General Larka.

As regards the coup carried out by the government on 12 March 1934, it is clear that diplomats from Great Britain, Germany, Finland, Latvia and Sweden doubted Päts's explanation of the need to avoid a coup by the Veterans. After the postponement of elections, the conviction deepened that Päts would continue the undemocratic rule indefinitely, and would not risk organising elections until he was sure of an election result that was beneficial to him. Although diplomats from both democratic and undemocratic countries residing in Estonia were forthright in their post-coup reports in calling the new Estonian system of government a dictatorship, their reports contained, besides a few ironic comments, no clear condemnation of the dismantling of democracy. After all, the authoritarian regime was in its repressions, relatively mild, the Estonian foreign policy course remained unchanged, and the court process in summer 1935 freed the Veterans of the coup-plotting charge, and did not result in severe penalties for the accused. 
The analysis of the relations between the six states and Estonia after 12 March is complicated, as previous researchers have mostly not raised the question of how it was affected by the 1934 coup and the establishment of an authoritarian regime. Based on the studies published so far, and the available documents in the archives of several countries, it can be concluded that the coup and the change of political regime did not damage Estonia's international position. On the contrary, the foreign ministries of a number of countries were understanding of Päts's actions, or even approved of them. Two dictatorships, the Soviet Union and Germany, were interested in increasing their influence in Estonia and the preservation of a democratic system of government was in comparison unimportant. Estonia's relations with the Soviet Union were not improved by Päts' remaining in power, and relations with Germany were not damaged because of the liquidation of the Veterans' movement, which had previously been accused of ties to the German National Socialists. Great Britain had decided to focus mainly on economic cooperation with Estonia. Considering the independence of the Baltic states to be uncertain, due to the proximity of the Soviet Union, the decision to avoid deeper political cooperation was made by Sweden, and following the latter's example, also Finland who had chosen a Scandinavian orientation. Estonia's relations with neighbouring Latvia were also not particularly close.

Lack of interest in closer political cooperation with Estonia could have resulted in the information that reached most of these states' capitals on Estonia, and especially on the Veterans, as being patchy, and also frequently contradictory since it was not considered necessary to collect more diverse information. In the following years, when the diplomats who witnessed the events had left Estonia, there already appeared in some British and German official documents praise regarding the efficiency of the authoritarian regime in Estonia compared to a democratic system of government.

In 1934 the replacement of a democratic government in Estonia with an authoritarian regime succeeded because of the combination of different factors. Firstly, the coup was supported by the clear majority of Estonia's existing political elite and media, whose views also dominated in the foreign diplomats' reports, and there being no resistance and no victims. And secondly, the interests of neighbouring countries and potential allies were elsewhere, and the foreign policy status quo offered by the coup organisers was seen as suitable by those major powers who were interested in influencing Estonia's future development. However, it is not known how the states being studied would have reacted to the coming to power of the Veterans after the 1934 April elections, since their foreign policy was initially hard to predict, and ties with Germany were unclear. 


\section{REFERENCES}

Akten zur deutschen auswärtigen Politik, 1918-1945: aus dem Archiv des Auswärtigen Amts, Serie C, 1933-1937. Band III, 1, Das dritte Reich: die ersten Jahre. 14. Juni bis 31. Oktober 1934. (1973), Göttingen, Vandenhoeck \& Ruprecht.

Arumäe, H. (2007), 1934. aasta 12. märts kaasaegsete hinnanguis. In: Velliste, A. (Ed.), Alasi ja haamri vahel. Tallinn, Konstantin Pätsi Muuseum, pp. 19-62.

Arumäe, H. (2018), Eesti ja Soome: sõjast sõjani. Tallinn, Argo.

Berg-Schlosser, D. (2002), Implications for Theories of Democracy. In: BergSchlosser, D. and Mitchell, J. (Eds.), Authoritarianism and democracy in Europe, 191939: comparative analyses. Basingstoke, Palgrave-Macmillan, pp. 319-323.

Bleiere, D., Butulis, I., Feldmanis, I., Stranga, A. and Zunda, A. (2014), History of Latvia: 100 years. Riga, Domas sēpks.

Buchanan, T. (2002), Anti-fascism and Democracy in the 1930s. European History Quarterly 32 (1), pp. 39-57. https://doi.org/10.1177/0269142002032001561

Capoccia, G. (2005), Defending Democracy: Reactions to Extremism in Interwar Europe. Baltimore and London, The Johns Hopkins University Press.

Carlgren, W. M. (1995), Rootsi ja Baltikum. Maailmasõdade vahelisest ajast sõjajärgsete aastateni. Ülevaade. Tallinn, Olion.

Carr, E. H. (1947), International Relations Between the Two World Wars. Houndmills, Macmillan.

Duhanovs, M., Feldmanis, I. and Stranga, A. (1994), Latvia and the year offateful decisions. Riga, University of Latvia.

Hinkkanen-Lievonen, M.-L. (1986), Britain as Germany's Commercial Rival in the Baltic States, 1919-1939. In: Recker M.-L. (Ed.), From competition to rivalry: the AngloGerman relationship in the countries at the European periphery, 1919-1939. Stuttgart, Steiner, pp. 15-49.

Ilmjärv, M. (2004a), Silent submission: formation of foreign policy of Estonia, Latvia and Lithuania: period from mid-1920s to annexation in 1940. Stockholm, Stockholms universitet.

Ilmjärv, M. (2004b), Eesti välispoliitika 1930. aastatel. In: Tannberg, T. (Ed.), Sõja ja rahu vahel. Koguteos. 1. köide: Eesti julgeolekupoliitika 1940. aastani. Tallinn, S-Keskus, pp. $51-73$.

Ilmjärv, M. (2010), Hääletu alistumine: Eesti, Läti ja Leedu välispoliitilise orientatsiooni kujunemine ja iseseisvuse kaotus 1920. aastate keskpaigast anneksioonini. $2^{\text {nd }}$ ed. Tallinn, Argo.

Jaanson, K. (2001), The Baltic Sea region in international relations of the twentieth century: The seminal nature of the interwar period. Journal of Baltic Studies 32 (3), 267-288. https://doi.org/10.1080/01629770100000091

Kasekamp, A. (1999), The Radical Right in Interwar Estonia. London, Macmillan Press.

Kasekamp, A. (2018), The Rise of the Radical Right, the Demise of Democracy, and the Advent of Authoritarianism in Interwar Estonia. In: Fleishman, L. and Weiner, A. (Eds.), War, Revolution, and Governance: The Baltic Countries in the Twentieth Century. Boston, Academic Studies Press, pp. 76-100. 
Ken, O. and Rupasov, A. (2002), Moskva i strany Baltii: opyt vzaimootnoshenii, 1917-1939 gg. In: Furman, D. E. and Zadorozhnyuk, E. G. (Eds.), Strany Baltii $i$ Rossija: obshestva i gosudarstva. Moscow, Referendum, pp. 225-256.

Ken, O. and Rupasov, A. (2014), Zapadnoye prigranichye: Politbyuro TsK VKP(b) i otnosheniya SSSR s zapadnymi sosednimi gosudarstvami, 1928-1934. Moscow, Algoritm.

Kenkmann, P. (2013), 1937. aasta põhiseadus - autoritaarse režiimi "reformimise" katse. Tuna (1), 70-89.

Knatchbull-Hugessen, H. (1949), Diplomat in Peace and War. London, John Murray.

Kuldkepp, M. (2016), Swedish political attitudes towards Baltic independence in the short twentieth century. Ajalooline Ajakiri (3/4), 397-430. http://dx.doi. org/10.12697/AA.2016.3-4.04

Lee, S. J. (1996), Aspects of British Political History 1914-1995. London, Routledge.

Leskinen, J. (2000), Vendade riigisaladus: Soome ja Eesti salajane sõjaline koostöö Nõukogude Liidu võimaliku rünnaku vastu aastatel 1918-1940. Tallinn, Sinisukk.

Linz, J. J. (1978), The breakdown of democratic regimes. Vol. 1, Crisis, breakdown, and requilibration. Baltimore and London, Johns Hopkins University Press.

Marandi, R. (1991), Must-valge lipu all, Vabadussõjalaste liikumine Eestis 1929-1937, I. Legaalne periood (1929-1934). Stockholm, Centre for Baltic Studies at the University of Stockholm.

Marks, S. (2003), The Illusion of Peace, International Relations in Europe, 1918-1933. Houndmills, Palgrave Macmillan.

Mudde, C. (2007), Populist radical right parties in Europe. Cambridge, Cambridge University Press.

Pajur, A. (2005), Suur kriis. In: Vahtre, S. (Ed.), Eesti ajalugu. VI, Vabadussõjast taasiseseisvumiseni. Tartu, Ilmamaa, pp. 81-91.

Pajur, A. (2018), Konstantin Päts. Poliitiline biograafia. II osa: riigimees (1917-1956). Tartu, Rahvusarhiiv.

Pearce, M. and Stewart, G. (1996), British Political History 1867-1995. Democracy and Decline. London, Routledge.

Powell M. J. (2003), The Battleground of High Politics: A Comparative Study of British and French Policies towards Poland and the Baltic States, 1917-1939. Lewes, Book Guild.

Riigikogu V koosseis. Stenograafilised aruanded. III ja IV istungjärk. (1934), Tallinn, Täht.

Rosenthal, R. and Tamming, M. (2013), Sõda enne sõda: Nõukogude eriteenistuste tegevusest Eestis kuni 1940. aastani. Tallinn, SE \& JS.

Salmon, P. (1988), British Security Interests in Scandinavia and the Baltic, 1918-39. In: Hinden, J. and Loit, A. (Eds.), The Baltic in international relations between the two world wars: symposium organized by the Centre for Baltic Studies, November 11-13, 1986, University of Stockholm, Frescati. Stockholm, Centre for Baltic Studies, pp. 113-136.

Stephens, J. D. and Kümmel, G. (2002), Class Structure and Democratization. In: Berg-Schlosser, D. and Mitchell, P. (Eds.), Authoritarianism and democracy in Europe, 1919-39: comparative analyses. Basingstoke, Palgrave-Macmillan, pp. 39-63.

Trencsényi, B., Kopeček, M., Lisjak Gabrijelčič, L., Falina, M. and Baar, M. (2018), A history of modern political thought in East Central Europe. Volume II, Negotiating 
modernity in the 'short twentieth century' and beyond. Part I, 1918-1968. Oxford, Oxford University Press.

Turtola, M. (1988), Aspects of the Finnish-Estonian Military Relations in the 1920s and 1930s. In: Hinden, J. and Loit, A. (Eds.), The Baltic in international relations between the two world wars: symposium organized by the Centre for Baltic Studies, November 11-13, 1986, University of Stockholm, Frescati. Stockholm, Centre for Baltic Studies, pp. 101-110.

Valge, J. (2009), Eesti vabadussõjalased ja Saksa natsionaalsotsialistid: ideoloogia, poliitiline taktika ja kontaktid. Tuna (3), 50-62.

Valge, J. (2011), Foreign Involvement and Loss of Democracy, Estonia 1934. Journal of Contemporary History 46 (4), 788-808. https://doi.org/10.1177/0022009411413408.

Valge, J. (2012), London, Berliin ja Moskva ning Eesti 1934. aasta riigipööre. Tuna (1), 38-61.

Valge, J. (2019), Eesti parlament 1917-1940: poliitiline ajalugu. Tallinn, Eesti Rahvusraamatukogu.

Zetterberg, S. (2021), Konstantin Päts ja Soome: unistus kaksikriigist. Tallinn, Varrak. 
https://doi.org/10.22364/hssl.29.1.02

\title{
THREE DECADES OF POST-SOVIET \\ PERIOD: ANALYSES OF OUTBOUND \\ TOURISM DEVELOPMENT PATTERNS \\ AND ENVIRONMENT IN LATVIA
}

\section{Ilze Medne}

Faculty of Business, Management and Economics, University of Latvia, Riga, Latvia

\author{
Kristīne Bērziṇa ${ }^{1}$ \\ Faculty of Business, Management and Economics, \\ University of Latvia, Riga, Latvia
}

\begin{abstract}
After regaining independence, the borders were opened for Latvian residents, and they had the possibility to leave behind the travel or non-travel principles of the Soviet Union period, as well as go into the global tourism market. PostSoviet transformation that was seen in different sectors, including the change in tourism and travel habits, which happened slowly. Since every decade of these three post-Soviet decades has its own development characteristics and is impacted by different external environment elements, the aim of this study is to analyse the tendencies of each decade and its most impactful external environment factors in Latvia. Even though the impact of the economic environment has always been meaningful in tourism, the main factor that impacted the first post-Soviet decade was without doubt the political environment. With the start of the $21^{\text {st }}$ century and the improvement of the economic situation, world's technological achievements enter Latvia's tourism industry. Different sociocultural factors highlight different outbound tourism tendencies in each decade. Travel habits of Latvian residents have changed over time - values and expectations have changed for travelling abroad. As expectations and knowledge increase, Latvian travellers join the tendencies and travel habits of the collective European travellers.
\end{abstract}

Keywords: tourism, outbound tourism, post-Soviet country, tourism development, macroeconomic environment

1 Contact: Kristīne Bērziṇa; kristine.berzina@lu.lv; Faculty of Business, Management and Economics, University of Latvia, Riga, LV-1050, Latvia. 


\section{Introduction}

The tourism industry is recognised as fragile and particularly sensitive to cyclical changes in countries of origin, as well as to global and regional economic conditions, political system and epidemics etc. (Detotto, Giannoni, Goavec, 2021). The post-Soviet transition process of political and economic changes was uneven among the Eastern European countries (Croes, Ridderstaat, Bak, Zientara, 2021), therefore the analyses of three decades of post-Soviet period of tourism development in Latvia will indicate the specific patterns that in a certain way can be characteristic for other Eastern European countries. Researchers of tourism development emphasise the importance of economic freedom by analysing differences in economic development and performance, highlighting public policy in the tourism sector and the importance of political stability in ensuring the sustainable development of tourism (Detotto, Giannoni, Goavec, 2021).

The tourism industry can be analysed through the following perspectives - domestic tourism, outbound tourism, inbound tourism, leisure tourism, business tourism (Gavurova, Suhanyi, Rigelsky, 2020). Travelling for leisure and for business purposes will be used in the analyses of outbound travel of Latvian residents. Generally, outbound tourism development and demand is a relatively less studied tourism type with a small number of published articles in comparison to the inbound tourism demand studies (Lin, Liu, Song, 2015; Gavurova, Suhanyi, Rigelsky, 2020), as outbound tourism describes import for the studied country. Outbound tourism development patterns and expenditures can be analysed both using a micro-level, as well as macro-level approaches. Outbound tourism macrolevel approach indicates overall patterns, economic development, and uses macroeconomic time series data in order to show aggregate expenditure tendencies of international tourism (Gozgor, Demir, 2018; Gavurova, Suhanyi, Rigelsky, 2020). Scholars outline the lack of research investigating tourism companies in developing countries, including the lack of studies analysing macroeconomic perspective of developing countries including Eastern Europe (Tleuberdinova, Shayekina, Salauatova, Pratt, 2021).

The aim of this article is to analyse the different decades of tourism development in post-Soviet period Latvia, especially outlining the first years after regaining independence, looking for the origins of outbound travel patterns in the transition period. The macroeconomic analyses are mainly based on the data provided by Central Statistical Bureau of Latvia. More specific tendencies and detailed explanations are compiled from the press starting from the early 1990s, as well as in-depth interviews with entrepreneurs were conducted in the period between February to August, 2020. 


\section{Opening the Soviet "iron curtain" for outbound travel in the 1990s. Influence of political environment on the development of tourism in Latvia}

Renewing Latvia's independence on May 4, 1990 fully opened the "iron curtain" that M. Gorbachov's political course had slowly started to open. The "iron curtain" is a symbol of ideological and economic isolation of the Soviet area from market led economies (Croes, Ridderstaat, Bak, Zientara, 2021). The free Latvian residents were now able to travel not only to republics of USSR, but also to other countries without needing "recommendations" from the communist youth and the communist party. From the time the constitutional law was agreed upon until the end of 1991, 93 countries recognised renewal of Latvia's independence and its national independence, but international recognition of the independence of Latvia continued in the following years. This process without doubt impacted the possibilities of Latvian residents to travel abroad, lessening the amount of bureaucratic procedures and the time needed for sorting them out.

After Latvia regained its independence, a question of importance was raised about what kind of personal documents the citizens of the renewed Latvia will use to travel abroad. A compromise was made - continuation of the previous documents people had and, in case it was necessary, continue giving out former USSR passports that were left under the control of Ministry of the Interior. Meanwhile, creation of Latvian identity documents was underway. A political decision was made to create three types of identity documents - citizen of Latvia passport, diplomatic Latvian passport and identity card for people without state. The first Latvian passports were handed out in June 1992 and became the official travel document of Latvian citizens. ${ }^{2}$

One factor that restricts travel is the necessity of having a visa to travel within another country, hence it was important to develop a nonvisa regime relationship with as many countries as possible after regaining the independence. The first countries that Latvia made a deal with to cancel the visa regime were United Kingdom, North Ireland, Czech Republic and Hungary (1993). In 1995, Baltic united visa area was expanded when "Protocol of migration politics" of Latvia, Estonia and Lithuania was signed. However, the implementation of non-visa regime was very slow from 1993-1997. Poland, Slovakia and Ireland were added to the list of countries mentioned above. In 1997, when Latvia's integration in the European Union was intensified, non-visa regime was possible with strategically

2 https://www.pmlp.gov.lv/lv/sakums/pakalpojumi/personu-apliecinosi-dokumenti/pases/ pases/latvijas-pasu-vesture/. 
important Scandinavian countries - Sweden, Finland, Denmark, Norway and Iceland. Switzerland, Lichtenstein, Andorra and Malta joined the list in 1998. Bilateral agreements were made with a selection of countries (Italy, Israel, Austria, Turkey, Croatia and Ukraine) for diplomatic and service passport holders to enter without needing a visa. In the summer of 1997, the government of Latvia approved a concept to develop a non-visa regime. This document determined the strategy for the implementation of a nonvisa regime between Latvia and foreign countries (Birkavs, 1998).

In the early 1990s, acquiring visas was very challenging for both unorganised travellers and tourist groups, because there were long queses to get a visa in addition to the fact that Latvia didn't have an embassy of every country. It was possible to get visas free of charge to countries like Italy, Denmark and Sweden, but to visit Finland one had to pay 20 US dollars, to Germany - 20 German marks, to Switzerland - 10 lats, to Israel - 7 lats, to Canada - 55 Canadian dollars (Pelūde un Neimanis, 1994; Indāns, 1994). It is noteworthy that it wasn't a small sum of money at that time - minimum wage during that time was 22-28 lats a month (Ministry of Welfare, Minimum Monthly Wage by Year). In the initial stage of the renewed Latvian state, different statistical collection methods were being developed, including data about the flow of travellers to and from Latvia, hence comprehensive statistical data does not exist about the travel of Latvian residents abroad in the early 1990s. The first published statistical data, complied by Border Guard forces of the Ministry of the Interior of Republic of Latvia, shows that more than two million Latvian residents crossed the border in 1993. By the end of the century, this number increased roughly $14 \%$, reaching more than two and a half million (see Table 1).

Table 1. Dynamics of Latvian travellers crossing Latvian border in 1993-2000

\begin{tabular}{|l|c|c|c|c|c|c|c|c|}
\hline \multicolumn{1}{|c|}{ Year } & 1993 & 1994 & 1995 & 1996 & 1997 & 1998 & 1999 & 2000 \\
\hline $\begin{array}{l}\text { Outgoing tourists from } \\
\text { Latvia (thsds) }\end{array}$ & 2269 & 1794 & 1812 & 1798 & 1877 & 1961 & 2256 & 2596 \\
\hline $\begin{array}{l}\text { Changes compared } \\
\text { with previous year, \% }\end{array}$ & $\mathrm{x}$ & -11 & +1 & -0.8 & +4.4 & +4.5 & +15 & +15 \\
\hline
\end{tabular}

Source: table made by authors based on Central Statistical Bureau of Latvia data

In the 1990s, travelling abroad was characterised by using motor vehicles, mostly tourist buses (see Table 2). Only 5-6\% of travellers used planes to travel abroad because this type of transportation was expensive, there weren't many air travel destinations from Riga airport, it wasn't as easy as it is now to purchase a plane ticket - it was only possible in airline representative offices and travel agencies. 
Table 2. Share of mode of transportation used by residents of Latvia for outgoing trips, 1995-2000,\%

\begin{tabular}{|l|c|c|c|c|c|c|}
\hline \multicolumn{1}{|c|}{ Year } & 1995 & 1996 & 1997 & 1998 & 1999 & 2000 \\
\hline Road transportation & 72.2 & 75.6 & 75.8 & 78.6 & 84.8 & 87.6 \\
\hline Railway transportation & 19.4 & 16.2 & 15.2 & 10.2 & 7.9 & 6.0 \\
\hline Air transportation & 5.8 & 5.9 & 5.9 & 6.5 & 5.7 & 5.2 \\
\hline Sea transportation & 2.5 & 2.3 & 3.1 & 4.7 & 1.6 & 1.2 \\
\hline
\end{tabular}

Source: table made by authors based on Central Statistical Bureau of Latvia data

Travelling abroad with a bus in the 1990s was an extreme adventure, often total costs were decreased by travel organisers offering trips with multiple nights on the bus - sometimes those were nights to or from a destination leading through Poland, but on longer trips nights were spent in the bus in the destination country. During that time, buses often were worn out "Hungarian Ikaruses" that were a far cry from today's comfortable tourist buses. These 15-20 years old worn out "Ikarus" buses tended to break down, and cause travellers and organisers big challenges while travelling.

Group bus trips in the early 1990s were associated with security challenges on the road. Lithuania-Poland transit road was considered a dangerous part of the journey when travelling with a bus. In the early 1990s, travellers were discouraged from stopping on the road because not only passengers on travel buses, but also passengers on long distance buses were victims to gangs of robbers in the Polish forests.

Safer travel and payment options overseas were ensured by travel cheques and international payment cards. From 1993, it was possible to purchase Thomas Cook and American Express travel cheques - money was turned into cheques in Latvia and then withdrawn in local currency in destination country. Travelling cheques made travellers feel safer going through countries that were considered unsafe, like, Poland, Lithuania, Russia and Belarus, because lost and stolen travel cheques could be renewed in any country within 24 hours. Latvian residents could use payment cards starting from mid 1990s, when Latvian banks obtained the rights to give out and service internationally recognised payment cards Eurocard/Mastercard, as well as payment card Visa Electron.

The so called "business trips" were popular in the 1990s, where people travelled to markets in Poland and other countries. At first, these trips were used to sell one's own products to afford travelling, but later - to purchase different goods for personal use and for selling them in Latvia. Markets in Lithuania, Turkey and United Arab Emirates were among the favourite destinations at the time. As purchasing power increased, Latvian residents 
started to travel to shopping tourism destinations of higher quality, such as German shopping centres and Italian fashion outlet centres.

Statistical data shows that in the 1990s railway transportation was the second most used travel transportation after motor vehicles. It was provided not only by the former USSR train lines to Moscow, but also by, for example, "Baltic Express" train that took the route Tallinn - Tartu - Valga Riga - Kaunas - Šeštokai - Warsaw. Every evening five minutes to midnight the train left from Riga central railway station to Kaunas, on the way crossing the Lithuanian border, where border guards checked passenger passports and train compartments. Early in the morning, the train arrived in Šeštokai (a town near the Polish border) where passengers had to change from a train suitable for USSR railway lines (1520mm wide) to a train for European railway lines (1435mm wide). That train then took travellers to Lithuania-Poland border, which used to be the last border of USSR, continuing to Warsaw. This route was started on May 22, 1993, but was closed in 1997 due to financial losses.

It was possible to travel to other European cities from the Polish capital. Back then, a journey from Riga to Vienna cost only 42 lats and 24 santims (Bicēna, 1995, 12). There was also a possibility to spend two nights and one day to get to Berlin with a direct train from Riga, but it was necessary for Latvian citizens to obtain a Belarus transit visa, since the train crossed its territory. In 58 hours it was possible to get to Sofia, however transit visas were also needed in this case because this train crossed territories of Belarus, Ukraine and Rumania.

In the early 1990s, Latvian residents also went to further travel destinations. The Tourist Club of University of Latvia in collaboration with Latvian High Mountain club, whose goal was to master world's highest summits, organised Latvia's first Himalayan expedition in 1993 led by one of the most notable Latvian alpinists - Teodors Kirsis. Organisers had arranged a TU-154 airplane to take a group of more than 100 people on adventures to Katmandu. For 10 days travellers had the opportunity to explore this exotic land, which only recently was made available to tourists. After the airline "Aeroflot" ceased its monopoly, four airlines offered regular and charter flights in the end of 1991. The largest of them was the heir of "Aeroflot" - "Latvijas Aviolinnijas" or "LatAvio" that offered passenger transportation to Copenhagen, Stockholm, Helsinki, Vienna, all of the capitals and specific state centres of Commonwealth of Independent States using Soviet Union style TU-154, TU-134 and AN-24 airplanes (Vucina, 1992). The well-known airlines of the world welcomed this new Latvian company with understanding and, rather than causing problems, helped it. Passengers were diverse - those who "don't count dollars" and those in poverty. At that time, "Latvijas Aviolīnijas" flights were the cheapest, but 
also lacked comfort and service, yet it was still considerably better than what people had gotten used to in "Aeroflot" airplanes over the years. However, during that time only a third of airplanes belonging to Latvian airlines were used because TU style airplanes were not well known and so were not a popular means of transport (Giga, 1993). The work of airline companies in the early 1990s was challenging. Airline companies collaborated with tourism agencies to ensure more airplanes were used, but the travel agencies had to get the expensive fuel. In 1992 charter flights to Beijing and Cairo, later to Tel Aviv and Tunis were organised in this way (Latvian airlines are in a difficult situation, 1992). In 1993, Riga international airport served 12920 airplanes and 310132 passengers, of which $70 \%$ were regular flights, $11 \%$ charter flights, $1 \%$ private flights and 9\% Russian air force that was still located in the territory of Riga airport (Celmiņšs, 1994).

Airline RIAIR or "Riga airline" was founded in 1992, which was another intermediate stage between Soviet Union time and Western aviation. In the beginning, it started passenger transportation with $S A A B-340$, later with Boeing aircrafts flying to Moscow and London. RIAIR had signed an Interline contract with "British Airways" and "Transaero" airlines that gave an opportunity to purchase RIAIR flights in "British Airways" ticket offices, and create connected flights with "Transaero" (Kusina, 1996, 25).

The creation of national airline "AirBaltic" was a notable turn in the development of outbound tourism. The airline was founded on August 28, 1995 as a limited company, after the national Latvian airline "LatAvio" was liquidated. It was founded by the government of Latvia together with Latvia-USA join venture "Baltic International Airlines" and Scandinavian airlines. The newly founded airline was owned by the state of Latvia with $51 \%$ of shares, the rest of the share owners were SAS $(28,5 \%)$, "Baltic International USA" (8\%) and two investment companies - "Swedfund International $A B$ " $(6,2 \%)$ and "Danish Investment Fund for Central and Eastern Europe (IO)" (6,2\%). First flights were started on October $1^{\text {st }}$ of the same year with the airplane Saab-340, but in 1996 the airline bought Avro RJ70. In the end of 1998, SAS bought all the shares owned by "Baltic International USA" and became actively involved in the management of the airline. In 1999, all Saab-340 "airBaltic" airplanes were replaced with Fokker 50 airplanes.

In 1995, "airBaltic" flew 559 flights and transported 13423 passengers. The following year it reached 4863 flights with 97428 passengers, but at the end of the century in 2000 the airline had flown 7999 flights with 219427 passengers. $^{3}$

\footnotetext{
3 "airBaltic" unpublished information
} 
In the early 1990s, multiple foreign country airlines started to offer air transportation services: Sandinavia's SAS, Germany's "Lufthansa”, Finland's "Finnair" (flights from Riga airport were started in spring, 1992), Poland's LOT (since March 1993), Czech Republic's ČSA.

Travelling habits of Latvian residents have changed over time, especially values and expectations that are important when travelling abroad. A large part of the trips in the 1990s looked like a sprint to the most popular tourist attractions in many countries. Sometimes, it was enough to just cross a country in transit for people to be content of the fact that they can add another country to the list of the countries they have visited. It was not that important, how long the visit lasted and what was seen, as long as there was something to add to the catalogue of visited countries.

Already starting from the early 1990s, most popular and most often visited destination countries could be distinguished - Latvia's neighbouring countries Lithuania, Estonia, Russia and Belarus; Central and Western European countries - Germany, Poland, France and Austria; as well as Northern European countries - Sweden, Finland and Denmark. USA was the most often visited country overseas (see Table 3).

Table 3. The most popular travel destinations for residents of Latvia

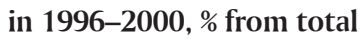

\begin{tabular}{|l|c|c|c|c|c|}
\hline \multicolumn{1}{|c|}{ Year } & 1996 & 1997 & 1998 & 1999 & 2000 \\
\hline Lithuania & 36.4 & 42 & 45.9 & 43.4 & 43.3 \\
\hline Estonia & 12.6 & 13.5 & 15.9 & 18 & 20.4 \\
\hline Russia & 19.9 & 16.6 & 14.9 & 14.8 & 17.7 \\
\hline Belarus & 9.1 & 10.2 & 7.5 & 9.8 & 7.9 \\
\hline Germany & 5.5 & 3 & 2.5 & 2.2 & 1.6 \\
\hline Poland & 4.9 & 3.5 & 3 & 2 & 1.6 \\
\hline Sweden & 1.7 & 3.5 & 2.4 & 1.7 & 1.5 \\
\hline Finland & 0.6 & 0.5 & 0.6 & 0.9 & 0.8 \\
\hline Ukraine & 1.7 & 2 & 1.2 & 0.8 & 0.4 \\
\hline Denmark & $\ldots$ & 0.4 & 0.8 & 0.8 & 0.4 \\
\hline France & 0.6 & 0.4 & 0.4 & 0.5 & 0.3 \\
\hline Austria & $\ldots$ & 0.2 & 0.3 & 0.6 & 0.4 \\
\hline USA & 0.3 & 0.3 & 0.3 & 0.6 & 0.5 \\
\hline
\end{tabular}

Source: table made by authors based on Central Statistical Bureau of Latvia data

Neighbouring countries Lithuania and Estonia were mostly visited in one day trips by Latvian residents. Shopping still was a popular reason for 
visiting Lithuania and Estonia. In 1996, only 15-20\% of Latvian travellers took a trip for more than one day. The most popular overnight trip destinations were the neighbouring countries Russia, Estonia, Belarus and Lithuania. Two thirds of overnight Latvian travellers visited these countries.

Table 4. The most popular destinations for overnight trips of residents of Latvia in 1998-2000, \% from total

\begin{tabular}{|c|c|c|c|}
\hline Year & 1998 & 1999 & 2000 \\
\hline Russia & 31.5 & 29.6 & 28.5 \\
\hline Estonia & 5.7 & 8.0 & 14.9 \\
\hline Belarus & 14.9 & 15.9 & 13.5 \\
\hline Lithuania & 14.2 & 12.0 & 11.5 \\
\hline Germany & 5.6 & 5.6 & 5.0 \\
\hline Poland & 6.9 & 4.9 & 4.9 \\
\hline Sweden & 3.2 & 3.5 & 4.0 \\
\hline Finland & 1.3 & 2.1 & 2.1 \\
\hline USA & $\ldots$ & 1.5 & 1.6 \\
\hline Ukraine & 2.8 & 1.9 & 1.4 \\
\hline Austria & 0.8 & 1.5 & 1.3 \\
\hline Denmark & 1.9 & 2.0 & 1.3 \\
\hline France & 1.0 & 1.3 & 0.8 \\
\hline
\end{tabular}

Source: table made by authors based on Central Statistical Bureau of Latvia data

The main motivation for travel was visiting friends and relatives, which can be explained by the large number of residents in Latvia originating from Russia and Belarus. Germany, Poland and Sweden were the most visited out of the other European countries.

The available information played a big role in choosing a travel destination. During the 1990s, looking up information was a complicated process. Portion of the travellers mainly relied on the recommendations from their friends or relatives, another portion looked up advertisements, more specifically adverts in newspapers, which during that time looked like small squares overfilled with text in tiny letters. Later, information was acquired through reading colourful tourism magazines, for example, "Celotprieks" that was started in October 1995. The first event that allowed travellers the opportunity to acquire a wide range of travel offers was "Balttour '94" tourism fair in January 1994, organised by Riga Cinema studio in an exhibition hall in Šmerlis. In the 1990s and later on, it was 
hard work for people to take part in the tourism fair "Balttour" because they went home with large piles of travel booklets and catalogues.

In case of starting an outbound tourism agency and tour operator business in the 1990s, one needed to have knowledge about travel destinations - where to go and what is going on there. Communication and reservation of hotels was done through fax to have written confirmation, the bills could be delivered through mail or fax. Information about interesting attractions was mainly given from person to person, hence meeting in tourism exhibitions was a very important way of getting and passing on information. Data compiled by The Statistical Committee of Republic of State of Latvia ${ }^{4}$ show that in Latvia in the end of 1991, 89 tourism companies provided tourism services to 278252 people, from which 161769 went abroad. However, these numbers need to be evaluated carefully since 1991 was the first year Latvia regained its independence, meaning that the previous practice was still in place, which only allowed travel abroad using package services provided by tourism companies. The following year, tourist count serviced by tourism companies notably decreased -36437 people, but by the end of the $20^{\text {th }}$ century increased to 112065 people.

In the last decade of the century, top 10 favourite travel destinations also changed that were visited by travellers from Latvia and provided by tourism company services (see Table 5). If in the first year of regaining independence people still chose the destinations they were used to during the Soviet times - neighbouring countries Lithuania and Estonia, former socialist block countries - Poland, Rumania, Czech Republic, Bulgaria and Hungary, as well as Germany, Finland and Sweden, then the following years Latvian residents also chose package trips to most popular worldwide travel destinations more often - France, Italy, Spain, and later - Turkey.

Table 5. The most popular package travel destinations of Latvian residents (TOP 10) 1991-2000

\begin{tabular}{|c|c|c|c|c|c|c|}
\hline \multirow{2}{*}{ Year } & \multicolumn{2}{|c|}{1991} & \multicolumn{2}{c|}{1995} & \multicolumn{2}{c|}{2000} \\
\cline { 2 - 7 } & Country & $\begin{array}{c}\text { Number of } \\
\text { outgoing } \\
\text { tourists }\end{array}$ & Country & $\begin{array}{c}\text { Number of } \\
\text { outgoing } \\
\text { tourists }\end{array}$ & Country & $\begin{array}{c}\text { Number of } \\
\text { outgoing } \\
\text { tourists }\end{array}$ \\
\hline 1. & Finland & 63384 & Turkey & 15812 & Turkey & 12516 \\
\hline 2. & Sweden & 5761 & Estonia & 4901 & Greece & 10648 \\
\hline 3. & Turkey & 3943 & Lithuania & 3657 & Germany & 6697 \\
\hline 4. & Germany & 3080 & Finland & 2335 & Spain & 6319 \\
\hline
\end{tabular}

4 From 1998 Central Statistical Bureau of Latvia 


\begin{tabular}{|c|c|c|c|c|c|c|}
\hline \multirow[b]{2}{*}{ Year } & \multicolumn{2}{|c|}{1991} & \multicolumn{2}{|c|}{1995} & \multicolumn{2}{|c|}{2000} \\
\hline & Country & $\begin{array}{c}\text { Number of } \\
\text { outgoing } \\
\text { tourists }\end{array}$ & Country & $\begin{array}{c}\text { Number of } \\
\text { outgoing } \\
\text { tourists }\end{array}$ & Country & $\begin{array}{c}\text { Number of } \\
\text { outgoing } \\
\text { tourists }\end{array}$ \\
\hline 5. & Lithuania & 2117 & Italy & 1492 & BENELUX & 5555 \\
\hline 6. & Italy & 1809 & Greece & 1068 & Lithuania & 5529 \\
\hline 7. & France & 1679 & In France & 1027 & Estonia & 5225 \\
\hline 8. & Spain & 1461 & $\begin{array}{l}\text { United } \\
\text { Kingdom }\end{array}$ & 913 & $\begin{array}{c}\text { United } \\
\text { Kingdom }\end{array}$ & 4687 \\
\hline 9. & Estonia & 1298 & Germany & 744 & Bulgaria & 4527 \\
\hline 10. & $\begin{array}{l}\text { United } \\
\text { Kingdom }\end{array}$ & 939 & Spain & 576 & Sweden & 3974 \\
\hline & Total & 161769 & Total & 42842 & Total & 112065 \\
\hline
\end{tabular}

Source: table made by authors based on Central Statistical Bureau of Latvia data

One of the first tourism companies in Latvia "Latvia Tours" was founded in 1992. Their first 3-4 tourist groups "Latvia Tours" organised for their employees and curious people to China and Manchuria. Classical outbound tourism started after that. "Latvia Tours" started more diverse outbound tourism activities after taking part in a tourism fair in Sweden (Solna, suburb of Stockholm).

When the borders of Latvia opened, residents of Latvia had the chance to visit their relatives abroad, which was used by the tourism company "Latvia Tours" in advertising opportunities for exiled Latvians to pay for their relatives' visits. In the exile newspaper "Laiks" there was an ad in the early 1990s:"Fellow citizens in America! Give a gift to your relatives, friends, acquaintances in Latvia. A trip abroad for $\$ 400.00-450.00$, InterLatvian travel agency "Latvia Tours"” (Newspaper "Laiks", 1991).

When the Olympic Committee of Latvia partnered up with "Latvia Tours", a complicated travel service experience was gained organising trips to multiple Olympic games and World sport veteran games. The beginning of one of the popular tourism companies "Impro Celiojumi" can be found in the University of Latvia Tourist club. The tourism company Travel centre "Impro" was founded in 1994 based on University of Latvia Tourist club. In their first year they took 1500 travellers on tours and drove more than 300 thousand $\mathrm{km}$ (Impro travel catalogue, 2014), spent 650 days while travelling, visited 25 countries, the average travel length was 13 days, average journey $6200 \mathrm{~km}$. The tourism routes organised by "Impro" were different from commercial trips organised by many other tourism companies because they included active leisure and had the chance to get to know the local culture. Shopping was not included in these routes. 
"Impro" travellers did not spend their nights in a hotel, but rather in tents and campsites, and they took their food with them on the road.

"Impro" travel groups were sometimes accompanied by well know public figures, like, virtuoso flamenco guitarist Andris Kārkliṇš in Spain, historian Vija Daukšte in Austria, director Arnis Ozols in France.

The first printed "Impro" travel catalogue was released in the end of 1995 offering 79 trips. The catalogue was black and white, 15 pages long, and in addition to trips offered boat trips, aerobics camps and meetup evenings with interesting people (the beginning of the club).

In September 1996, travel club "Impro" was founded, which was one of the many ways Travel centre "Impro" was expressing itself. It offered a chance to meet people interested in travelling and active lifestyle. Annual "Impro" traveller parties were legendary.

Another way how travel was organised in Latvia was not only through sport, but also other interest organisations. That is how in the early 1990s "Studentu Iniciativvas Fonds" was founded as a non-profit officially distributing International Student Identity Cards ISIC. Later this organisation was changed to a tourism agency "Kolumbs".

Travel bureau "Via Rìga" was launched in the spring of 1993 by the international tourism agency chain "Lufthansa City Centre" franchiser. Added competitiveness was ensured by a unique opportunity at the time to directly sell trips from the German mega tour operator TUI and "DerTour" catalogues. Everyone had the chance to enter the "Lufthansa City Centre" and simply buy an airplane ticket or a trip. Demand was huge, it was common to have queues and extra hours after work. High standards, focus on the individual customer service and selling airplane tickets became the foundation for corporate charter client and a business trip service segment to quickly develop. Their first charter clients were mostly representatives from foreign companies, to whom advantages were offered - the possibility to pay for services afterwards within a specific time period, and travel document shipment was also made available later. Demand for such services increased quickly, especially when government institutions started to make purchase deals for services to organise business trips.

\section{Ups and downs in outbound trips at the beginning of $21^{\text {st }}$ century. Influence of economic and technological environment on tourism development in Latvia}

The headline of the first decade of the new century was the fact that Latvia joined the EU on May $1^{\text {st }}, 2004$, and the Schengen agreement or Schengen zone on $21^{\text {st }}$ December, 2007. These both occurrences contributed 
to the possibility for Latvian residents to travel abroad, as well as made travelling between countries easier, since there was no need to waste time on borders for passport control.

In this period, the number of Latvian residents travelling abroad steadily continued to increase: if the total border crossing count in the 10 -year period increased roughly $17 \%$, then overnight trip count almost doubled (see Table 6). A drop of roughly $14 \%$ was seen in border crossings and overnight trips in 2008/2009 because of the global financial crisis. However, already in 2010 travel count abroad started to rise again.

Table 6. Outbound trips of Latvian residents in 2001-2010

\begin{tabular}{|c|c|c|c|c|c|}
\hline Year & $\begin{array}{c}\text { Border crossings } \\
\text { outgoing } \\
\text { tourist number } \\
\text { (thousands) }\end{array}$ & $\begin{array}{c}\text { Trips for } \\
\text { several days } \\
\text { (thousands) }\end{array}$ & $\begin{array}{c}\text { Expenditures } \\
\text { abroad (mil. } \\
\text { Euro) }\end{array}$ & $\begin{array}{c}\text { Average } \\
\text { trip length }\end{array}$ & $\begin{array}{c}\text { Average } \\
\text { expenditures } \\
\text { per day } \\
\text { (Euro) }\end{array}$ \\
\hline 2001 & 2651 & 838.8 & 194.9 & 2.8 & 27 \\
\hline 2002 & 2310 & 922 & 195.5 & 3.4 & 26 \\
\hline 2003 & 2299 & 1092.8 & 259.7 & 3.6 & 31 \\
\hline 2004 & 2456 & 1061.7 & 281 & 2.9 & 38 \\
\hline 2005 & 2894 & 1402.1 & 458.2 & 3.2 & 50 \\
\hline 2006 & 3114 & 1687 & 575.7 & 3.8 & 48 \\
\hline 2007 & 3376 & 1666.5 & 689.8 & 3.8 & 53 \\
\hline 2008 & 3524 & 1836.5 & 832.5 & 4.0 & 60 \\
\hline 2009 & 3058 & 1573.5 & 581.1 & 4.7 & 41 \\
\hline 2010 & 3090 & 1650 & 523.9 & 4.9 & 34 \\
\hline Changes, \% & +16.6 & +96.7 & +168.8 & +75 & +25.9 \\
\hline
\end{tabular}

Source: table made by authors based on Central Statistical Bureau of Latvia data

If in the 1990s people chose to travel once a year, then in the $21^{\text {st }}$ century it was more characteristic to travel more often. Statistical data also shows large amounts of total money spent on trips abroad. The total amount spent on trips abroad until the pre-crisis wealthy years had increased more than four times. The average travel length abroad also dramatically increased, in 2010 Latvian residents spent 4.9 days on average on their trips.

In this decade, the priorities of Latvian overnight travellers also dramatically changed - neighbouring countries Russian and Estonia were changed to Germany and Sweden (see Table 7). 
Table 7. The most popular overnight travel destinations for residents of Latvia in 2001-2010, \% from total overnight travellers

\begin{tabular}{|l|c|c|c|c|c|c|c|c|c|c|}
\hline \multicolumn{1}{|c|}{ Year } & $\mathbf{2 0 0 1}$ & $\mathbf{2 0 0 2}$ & $\mathbf{2 0 0 3}$ & $\mathbf{2 0 0 4}$ & $\mathbf{2 0 0 5}$ & $\mathbf{2 0 0 6}$ & $\mathbf{2 0 0 7}$ & $\mathbf{2 0 0 8}$ & $\mathbf{2 0 0 9}$ & $\mathbf{2 0 1 0}$ \\
\hline Germany & 7.5 & 7.7 & 11.0 & 8.2 & 10.4 & 12.1 & 14.7 & $\mathbf{1 7 . 4}$ & $\mathbf{1 6 . 2}$ & $\mathbf{1 4 . 1}$ \\
\hline Lithuania & 10.7 & 11.2 & 12.0 & $\mathbf{1 7 . 6}$ & 11.3 & $\mathbf{1 4 . 2}$ & $\mathbf{1 5 . 5}$ & 12.8 & 12.5 & 11.8 \\
\hline Sweden & 2.4 & 5.1 & 6.8 & 7.0 & 5.7 & 6.6 & 8.5 & 7.9 & 11.0 & 10.9 \\
\hline Russia & $\mathbf{2 5 . 3}$ & $\mathbf{2 3 . 8}$ & $\mathbf{1 7 . 0}$ & 14.4 & $\mathbf{1 3 . 2}$ & 10.6 & 9.6 & 8.4 & 10.3 & 10.6 \\
\hline Poland & 6.4 & 6.1 & 6.7 & 8.2 & 9.4 & 9.1 & 6.2 & 5.6 & 5.5 & 6.4 \\
\hline Italy & 1.4 & 1.2 & 2.8 & 2.0 & 2.8 & 2.9 & 3.6 & 4.4 & 5.1 & 6.4 \\
\hline Estonia & 14.1 & 14.8 & 11.9 & 11.6 & 6.7 & 5.3 & 4.8 & 6.6 & 4.6 & 4.1 \\
\hline France & 1.0 & 2.3 & 3.2 & 1.7 & 2.7 & 2.4 & 2.0 & 2.7 & 2.8 & 3.7 \\
\hline $\begin{array}{l}\text { United } \\
\text { Kingdom }\end{array}$ & $\ldots$ & $\ldots$ & $\ldots$ & $\ldots$ & 2.7 & 4.1 & 3.7 & 1.8 & 2.6 & 3.3 \\
\hline Austria & 1.2 & 1.5 & 2.8 & 2.8 & 4.0 & 2.7 & 2.5 & 2.6 & 2.3 & 3.0 \\
\hline Finland & 2.1 & 2.5 & 2.3 & 2.6 & 2.2 & 1.8 & 1.4 & 1.2 & 2.4 & 2.3 \\
\hline USA & 2.0 & 1.4 & 1.2 & 1.6 & 1.9 & 2.0 & 1.8 & 3.2 & 2.3 & 2.2 \\
\hline Belarus & 10.8 & 5.8 & 4.1 & 3.7 & 3.6 & 3.1 & 1.8 & 1.8 & 2.1 & 1.8 \\
\hline Norway & 0.4 & 1.1 & 1.4 & 1.6 & 0.7 & 1.3 & 1.7 & 1.7 & 2.3 & 1.7 \\
\hline Belgium & 0.7 & 0.7 & 0.9 & 1.0 & 2.8 & 1.6 & 1.9 & 1.9 & 1.6 & 0.9 \\
\hline
\end{tabular}

Source: table made by authors based on Central Statistical Bureau of Latvia data

Thanks to the fact that the overall economic situation in Latvia improved, low-cost airlines "Ryanair" (2004), "EasyJet" (2004) and "WizzAir" (2010) entered Latvia's market, and the use of air transportation sharply increased in international tourism of Latvia. It can be seen in the statistical data about the transportation used by Latvian residents travelling abroad (see Table 8), as well as in the increase of served passengers in airport "Rīga". Already in 2004 for the first time in the airport's history the served number of passengers went over 1 million in a year's time (1.06 million). In 2005, the airport served 1.9 million passengers, but in 2006 the number of passengers served reached 2.5 million. Moreover in 2007, the international airport "Rīga" served 3.16 million passengers, and in 2008 the passenger number reached 3.7 million. Despite the economic crisis of 2009, the airport served 4.07 million passengers (increase of $10.2 \%$, in comparison to 2008), but in 2010 the number of passengers reached 4.66 million (increase of $14.5 \%$ in comparison to 2009 ). ${ }^{5}$ In 2010 , it was possible to directly (without

${ }^{5}$ https:/www.riga-airport.com/uploads/files/Statistika/6_RIX_Statistics\%202020_Jun.pdf. 
changing to another flight) fly to 82 destinations from "Rīga" airport (International airport "Riga", 2010).

Table 8. Share of mode of transportation used by residents of Latvia for outgoing trips 2001-2010, \% from border crossings

\begin{tabular}{|l|c|c|c|c|}
\hline Year & Air transportation & $\begin{array}{c}\text { Road } \\
\text { transportation }\end{array}$ & Sea transportation & $\begin{array}{c}\text { Railway } \\
\text { transportation }\end{array}$ \\
\hline 2001 & 5 & 89 & 1 & 5 \\
\hline 2002 & 7 & 86 & 2 & 5 \\
\hline 2003 & 8 & 83 & 3 & 6 \\
\hline 2004 & 10 & 82 & 3 & 5 \\
\hline 2005 & 15 & 78 & 3 & 4 \\
\hline 2006 & 18 & 76 & 2 & 3 \\
\hline 2007 & 23 & 71 & 3 & 5 \\
\hline & Overnight travellers & & & 5 \\
\hline 2008 & 56 & 32 & 9 & 5 \\
\hline 2009 & 56 & 30 & 9 & \\
\hline 2010 & 57 & 29 & & \\
\hline
\end{tabular}

Source: table made by authors based on Central Statistical Bureau of Latvia data

When "Ryanair" entered the air transportation market as a low-cost airline with cheap ticket prices, aviation transport suddenly became an available commodity to a large part of the market. It grew the market, created new demand (even though in addition to the cheap ticket price people had extra expenses, such as, luggage fees, meals, the airport was often far away from the destination that created extra transportation expenses). It stimulated reorganisation of the existing price strategy, and later of the offered product strategy by competitive traditional airlines, because a fight for the market part in specific routes was started.

A notable contribution to traveller transportation in the first decade of the $21^{\text {st }}$ century was given by the airline "airBaltic": in the first five years of the decade the number of transported passengers increased more than 4 times, in 2005 for the first time going over 1 million, but at the end of the decade in 2010, it went over 3 million or 3206735 passengers. ${ }^{7}$

6 Due to changes in the methodology for compiling and presenting statistical data, the LR CSP shows the use of transport for only multi-day travellers from 2008 onwards.

7 "airBaltic" unpublished information. 
The eruption of Eyjafjallajökull volcano in Iceland in 2010 created challenges for Latvian travellers and air transportation providers alike. The eruption started on April 14, 2010 and lasted till the middle of June with giant ash clouds disrupting more 100000 flights and creating chaos in the aviation transport of Europe, causing the air space to be closed, which had not happened since World War II. The ash cloud reached Latvia after 2 days causing to cancel all "airBaltic" flights and decreasing the International airport "Riga" passenger count by $9.2 \%$ and the flight count by 5\% (International airport Rīga, 2010). More than eight million travellers lived in the airports of Europe for days on end waiting for the renewal of air traffic.

Transition to digital airplane tickets created rapid change in travel possibilities, including passenger data digitalization. In the late 1990s, tickets still had to be printed on paper, data had to be manually written by hand, and people had to anticipate ticket delivery expenses and the time it takes. This system changed in the summer of 2008 when IATA (International Air Transport Association) decided to adopt digital airplane tickets. Digital airplane tickets could be reserved and paid for online, and since the confirmation is sent in a digital format to their e-mail, it is instant service and a comfortable way of making sure that all data is correct. Essentially, a digital airplane ticket is an entry in the airline's computer system about the passenger and their chosen flight route.

The first airline in Latvia that changed to e-tickets was "British Airways". It was a difficult time to be a pioneer because a lot of passengers were desperate when they did not have a paper ticket in their hand, they did not have something to report to the accounting, only the flight route or itinerary could be taken to the embassy. The online check-in was also pioneered by "British Airways".

There was also a possibility to go abroad with a ferry. Since 2006, passenger transportation from Riga passenger port on the route Riga Stockholm was carried out by the shipping company joint-stock company "TALLINK Group". From Ventspils there were ferry companies "StenaLine" going to Nynäshamn in Sweden, Rostock and Travemünde in Germany. From Liepāja it was possible to go to Travemuinde initially by the company "Scandlines", later with "StenaLine" ferries.

In the beginning of $21^{\text {st }}$ century (2001), from the 129 tourism companies that provided tourism services, 107 tourism companies serviced 137701 travellers leaving Latvia. By the end of the decade, the total number of tourism companies increased more than two times - 284 , but the number of serviced Latvian travellers going abroad using tourism company services increased to 298645 people. Assuming that tourism company services are used by overnight travellers, in 2001 they were more 
than $16 \%$ of the total Latvian travellers going abroad for multiple days. But at the end of the decade in 2010 - 18\%; a slight increase can be seen, which means that in this time Latvian travellers still use tourism company services, even though more ways of organising travel themselves become available. As can be seen in Table 9, in one decade the most popular package travel destination list changed from northern countries to Turkey and Greece.

Table 9. The most popular package travel destinations of Latvian residents (TOP 10) 2001-2010

\begin{tabular}{|c|l|c|l|l|l|c|}
\hline Year & \multicolumn{2}{|c|}{2001} & \multicolumn{2}{c|}{2005} & \multicolumn{2}{c|}{2010} \\
\hline & \multicolumn{1}{|c|}{ Country } & $\begin{array}{c}\text { Number of } \\
\text { travellers }\end{array}$ & Country & $\begin{array}{c}\text { Number of } \\
\text { travellers }\end{array}$ & \multicolumn{1}{|c|}{ Country } & $\begin{array}{c}\text { Number of } \\
\text { travellers }\end{array}$ \\
\hline 1. & Finland & 10597 & Turkey & 40581 & Turkey & 41990 \\
\hline 2. & Sweden & 10183 & Estonia & 12049 & Estonia & 15599 \\
\hline 3. & Turkey & 9974 & Lithuania & 11764 & Lithuania & 15535 \\
\hline 4. & Germany & 8562 & Finland & 10853 & Finland & 12774 \\
\hline 5. & Lithuania & 7344 & Italy & 10691 & Italy & 9542 \\
\hline 6. & Italy & 6275 & Greece & 10174 & Greece & 9525 \\
\hline 7. & France & 5443 & In France & 10031 & In France & 9221 \\
\hline 8. & Spain & 5430 & $\begin{array}{l}\text { United } \\
\text { Kingdom }\end{array}$ & 9869 & $\begin{array}{l}\text { United } \\
\text { Kingdom }\end{array}$ & 8279 \\
\hline 9. & Estonia & 4939 & Germany & 9714 & Germany & 7843 \\
\hline 10. & $\begin{array}{l}\text { United } \\
\text { Kingdom }\end{array}$ & 4826 & Spain & 9386 & Spain & 7681 \\
\hline & Total & 128369 & Total & 272914 & Total & 298645 \\
\hline & Africa & 3369 & Africa & 27057 & Africa & 34762 \\
\hline & Asia & 368 & Asia & 8261 & Asia & 11225 \\
\hline
\end{tabular}

Source: table made by authors based on Central Statistical Bureau of Latvia data

In the beginning of $21^{\text {st }}$ century, the demand for charter flights rapidly increased - almost doubled in comparison to the previous years. The charter flights organizsed by tour operators did not significantly differ from one another, for example, in 2002, "Alida Tours", "Begonija", "Planēta", "Novatour", "Tez Tour" and "Juniversal" offered charter flight tours to Antalya and Marmaris (Turkey), select tour operators also organised charter flight tours to Crete (Greece), Barcelona (Spain); "Domina Travel Latvia" offered tours to Croatia, Tunis and Egypt (Dienas Bizness, 2002). This tendency explains the changes seen in the destination TOP 10 in favour of the destinations offered in the charter flights mentioned above. 
With the beginning of a new century, two powerful tour operators entered the Latvian market - "Novatours" and "Tez Tour" (part of the international tourism holding "TEZ TOUR Group). In 2005, the first two online airplane ticket stores were created: letasaviobiletes.lv and lidot. $l v$, at first, they sold airline airplane tickets, but in time they broadened their offers with other services and the so-called dynamic packaging the possibility to combine various necessary travel services. Later (2007), the airplane ticket reservation portal aviokase.lv was created.

After the first airplane ticket selling and comparing portals started to operate in Latvia, the next step was in 2007, when travel portal "Celıjumu bode" entered the market, which offered a possibility to compare and purchase different tour operator trips. The portal had gathered over 20 tour operator and agency offers. When asked to characterise their clients, the portal emphasises that in 2010 and 10 years later not much has changed, still mostly it is being used by people aged 25-60. However, the travel experience has increased, Latvian travellers can better appreciate opportunities in one destination or the next. ${ }^{8}$

New topical tourism products and reservation platforms following the demand tendencies were created by a portion of tourism agencies, for example, Baltijas SPA hotel offer reservation platform "GoSpa".

Tourism company observations indicate that 2008/2009 economic crisis brought change to traveller buying behaviour: "People chose trips one grade "lower" in this time than what they allowed themselves in the previous years. Even 30-40 EUR were of importance per person when choosing a trip. This kind of difference in prices could change a client's choice in an instant in favour of another trip." (Mackevičs un Veško, 2010).

\section{Experienced travellers of the $2^{\text {nd }}$ decade of the $21^{\text {st }}$ century. Influence of monetary integration and sociocultural environment on tourism development in Latvia}

During the crisis period, it was observed that residents of Latvia chose travelling within Latvia rather than abroad. In the period 2010-2011, the number of local visitors in tourism housing in Latvia increased for more than $20 \%$ each year. This choice was enforced by the thin wallets so to say that limited the option of going on more expensive and longer trips, as well as the desire to "warm up" the Latvian economy by increasing income of local tourism housing and other leisure service providers. In 2011, as the income of households increased the flow of travellers going abroad started to renew (Rutkovska, 2013).

8 http://m.travelnews.lv/?pid $=108456$. 
The spread of the Schengen zone continued to increase travel options abroad for Latvian residents. Now there are 26 Schengen zone member states with full rights: 22 EU member states and Norway, Iceland, Switzerland and Lichtenstein. Ireland has not signed the convention; however, it fulfils select convention conditions and manages the total travel space with United Kingdom. Bulgaria, Rumania and Cyprus are ready to join, but for various reasons the joining of these countries has been postponed. Croatia started their joining process in 2015. After the migration crisis and the increase of terrorist threats, multiple Schengen zone countries reintroduced control measures on their borders. These control measures were prolonged multiple times, the last one till April 30, 2018 in regards to France, and till May 12, 2018 in regards to Austria, Denmark, Germany, Sweden and Norway. In the middle of March 2020, almost all of the EU member states closed off their borders with other European countries due to the global Covid-19 pandemic. Causing the Schengen zone, which had just celebrated its 35 anniversary, to practically stop functioning. However, there were a few countries that did not close off their inner borders, among them were Luxemburg, The Netherlands, Ireland, United Kingdom. After the European Commission asked to open the inner borders starting from June 15, 2020, many EU member states reopened their inner borders. Covid-19 pandemic had a devastating impact on the flow of international tourism in general, as well as on Latvian travellers in their options to travel to other countries of the world.

Starting from January $1^{\text {st }}, 2014$ Latvia joined the Eurozone and became the $18^{\text {th }}$ country to implement the Euro. Joining the Europe's joint currency made it easier to make financial transactions while travelling abroad, tourists did not lose money in commission fees while converting money in currency exchange points and while purchasing travel services on the internet. Euro also gave the possibility to exchange currency on the spot in the destination even when travelling outside the Eurozone countries.

The Latvian tourist travel flow is characterised by small wavelike fluctuations in the first half of the second decade of this century, minimum was reached in 2015. In the next four years a steady increase was seen in the number of travels abroad, reaching the maximum across all types in 2019 (see Table 10). 
Table 10.Outbound trips of residents of Latvia in 2011-2019

\begin{tabular}{|l|c|c|c|c|c|c|}
\hline \multicolumn{1}{|c|}{ Year } & $\begin{array}{c}\text { Border } \\
\text { crossings } \\
\text { outgoing } \\
\text { tourist } \\
\text { number } \\
\text { (thousands) }\end{array}$ & $\begin{array}{c}\text { Trips for } \\
\text { several } \\
\text { days } \\
\text { (thousands) }\end{array}$ & $\begin{array}{c}\text { Expen- } \\
\text { ditures } \\
\text { abroad } \\
\text { (mil. Euro) }\end{array}$ & $\begin{array}{c}\text { Average } \\
\text { trip } \\
\text { length }\end{array}$ & $\begin{array}{c}\text { Average ex- } \\
\text { penditures } \\
\text { per day } \\
\text { (Euro) }\end{array}$ & $\begin{array}{c}\text { Average ex- } \\
\text { penditures } \\
\text { per day } \\
\text { (Euro) }\end{array}$ \\
\hline 2011 & 1530 & 11987 & 7.8 & 446.8 & 292 & 37.3 \\
\hline 2012 & 1397.5 & 8233.2 & 5.9 & 480.3 & 343.7 & 58.3 \\
\hline 2013 & 1246.1 & 7951.1 & 6.4 & 481.3 & 386.2 & 60.5 \\
\hline 2014 & 1362.1 & 8661.1 & 6.4 & 472.9 & 347.2 & 54.6 \\
\hline 2015 & 1241.7 & 6702.9 & 5.4 & 447.0 & 360 & 66.7 \\
\hline 2016 & 1249.8 & 7406.6 & 5.9 & 430.0 & 344 & 58 \\
\hline 2017 & 1265.4 & 6837.4 & 5.4 & 522.1 & 412.6 & 76.4 \\
\hline 2018 & 1368.4 & 7311.6 & 5.3 & 521.4 & 381 & 71.3 \\
\hline 2019 & 1479.8 & 8927.5 & 6 & 741.8 & 501.3 & 83.1 \\
\hline Changes, \% & -3.3 & -25.6 & -23.1 & +66 & +71.7 & +122.8 \\
\hline
\end{tabular}

Source: table made by authors based on Central Statistical Bureau of Latvia data

Small changes in this decade can also be seen in the destinations Latvian residents chose for overnight trips (see Table 11). In 2011, at the top of the list of the most popular countries were Germany, Lithuania, Sweden and Russia, attracting approximately $45 \%$ of the total Latvian travellers. In 2019, the most popular destinations Latvian residents travelled to were Lithuania, Estonia, Russia and Sweden, attracting slightly more than 35\% of Latvian overnight travellers.

Table 11. The most popular package travel destinations of Latvian residents (TOP 10) 2011-2019, \% from total overnight travellers

\begin{tabular}{|l|c|c|c|c|c|c|c|c|c|}
\hline \multicolumn{1}{|c|}{ Year } & $\mathbf{2 0 1 1}$ & $\mathbf{2 0 1 2}$ & $\mathbf{2 0 1 3}$ & $\mathbf{2 0 1 4}$ & $\mathbf{2 0 1 5}$ & $\mathbf{2 0 1 6}$ & $\mathbf{2 0 1 7}$ & $\mathbf{2 0 1 8}$ & $\mathbf{2 0 1 9}$ \\
\hline Lithuania & $\mathbf{1 1 . 4}$ & $\mathbf{1 0 . 9}$ & 9.9 & $\mathbf{1 1 . 4}$ & $\mathbf{1 3 . 8}$ & $\mathbf{1 7 . 0}$ & $\mathbf{1 2 . 1}$ & $\mathbf{1 1 . 5}$ & $\mathbf{1 1 . 2}$ \\
\hline Estonia & 5.0 & $\mathbf{1 0 . 1}$ & $\mathbf{1 2 . 7}$ & $\mathbf{7 . 0}$ & $\mathbf{1 3 . 6}$ & $\mathbf{1 6 . 8}$ & $\mathbf{1 3 . 7}$ & $\mathbf{1 5 . 1}$ & $\mathbf{1 0 . 9}$ \\
\hline Russia & $\mathbf{1 0 . 5}$ & 9.4 & $\mathbf{1 3 . 0}$ & $\mathbf{1 0 . 1}$ & $\mathbf{9 . 7}$ & $\mathbf{9 . 8}$ & 6.7 & $\mathbf{8 . 6}$ & $\mathbf{6 . 9}$ \\
\hline Sweden & $\mathbf{1 0 . 5}$ & 8.3 & 7.8 & 6.3 & 6.0 & 5.2 & 6.3 & 7.3 & 6.8 \\
\hline Germany & $\mathbf{1 3 . 0}$ & $\mathbf{9 . 6}$ & 7.6 & $\mathbf{7 . 0}$ & 5.8 & 6.7 & $\mathbf{1 1 . 7}$ & 5.8 & 6.6 \\
\hline $\begin{array}{l}\text { United } \\
\text { Kingdom }\end{array}$ & 3.1 & 5.5 & 6.4 & 6.8 & 5.5 & 4.1 & 4.2 & 5.2 & 4.7 \\
\hline Belarus & 1.4 & 5.6 & 4.4 & 4.9 & 3.4 & 3.1 & 6.0 & $\ldots$ & 5.3 \\
\hline
\end{tabular}




\begin{tabular}{|l|c|c|c|c|c|c|c|c|c|}
\hline \multicolumn{1}{|c|}{ Year } & $\mathbf{2 0 1 1}$ & $\mathbf{2 0 1 2}$ & $\mathbf{2 0 1 3}$ & $\mathbf{2 0 1 4}$ & $\mathbf{2 0 1 5}$ & $\mathbf{2 0 1 6}$ & $\mathbf{2 0 1 7}$ & $\mathbf{2 0 1 8}$ & $\mathbf{2 0 1 9}$ \\
\hline Italy & 6.2 & 4.6 & 2.4 & 4.4 & 5.1 & 5.8 & $\ldots$ & $\ldots$ & $\ldots$ \\
\hline France & 4.3 & 2.3 & 2.4 & 2.7 & 4.5 & $\ldots$ & $\ldots$ & $\ldots$ & 3.8 \\
\hline Poland & 5.9 & 5.0 & 3.2 & 3.5 & 4.1 & 3.7 & $\ldots$ & $\ldots$ & $\ldots$ \\
\hline
\end{tabular}

Source: table made by authors based on Central Statistical Bureau of Latvia data

Without doubt, air transportation remained the leader as a means of transport for overnight trips abroad, at the same time travelling by bus or ship decreased (see Table 12).

This tendency can be also seen in the data collected by the national airline "airBaltic" - in the time frame 2011-2019, the airline's flight number grew from 55319 to 62748 , but the number of serviced people grew from 3.35 million. to 5.05 million. Furthermore, the total number of passengers of the International airport "Rigga" went over 7.06 million at the end of 2018, in a year's time increasing by $15.7 \%$. In 2018, 19 airlines worked in airport "Rìga". Almost 55\% or 3.8 million passengers from the total passenger number was managed by the national airline "airBaltic", 15\% Irish low-cost airline "Ryanair", and 8.4\% - Hungarian low-cost airline "Wizz Air". In the summer flight season of 2018, "Rīga" offered their passengers the most extensive route net in the history of the airport - 100 destinations, but in winter season it was possible to go to 77 destinations from Riga. TOP 10 destinations of International airport "Rìga" in 2018 were London, Moscow, Helsinki, Oslo, Stockholm, Frankfurt, Berlin, Tallinn, Kiev and Copenhagen (Riga International Airport, 2018).

Table 12.Share of mode of transport used by residents of Latvia for outgoing trips 2011-2019, \% from border crossings

\begin{tabular}{|l|c|c|c|c|c|}
\hline Year & Airplane & Passenger car & Bus & Ship & Other \\
\hline 2011 & 57 & 29 & & 9 & 5 (train) \\
\hline 2012 & 36 & 36.4 & 17.7 & 8.1 & 1.8 (train) \\
\hline 2013 & 38.1 & 34 & 17.8 & 7.5 & $\begin{array}{c}2.4 \text { (train)/ } \\
0.2 \text { (bicycle) }\end{array}$ \\
\hline 2014 & 51.6 & 25 & 12.3 & 5.7 & $\begin{array}{c}3.6 \text { (train)/ } \\
1.8 \text { (bicycle) }\end{array}$ \\
\hline 2015 & 39 & 36 & 15.4 & 6.4 & 3.2 \\
\hline 2016 & 36.8 & 35.5 & 17.6 & 6.8 & 3.3 \\
\hline 2017 & 43.2 & 34.9 & 12.8 & 7 & 2.1 \\
\hline 2018 & 46.1 & 34 & 11 & 7.2 & 1.7 \\
\hline 2019 & 51 & 32.3 & 9.3 & 5.1 & 2.3 \\
\hline
\end{tabular}

Source: table made by authors based on Central Statistical Bureau of Latvia data 
In the first half of 2020, due to Covid-19 pandemic international passenger transport dramatically decreased: 1.3 million people flew in and out of airport "Rìga", which is $62.9 \%$ less compared to the first half of 2019. In the first 6 months of 2020, 206.9 thousand passengers came in and out of ports of Latvia with ferries, which is $57.2 \%$ less than the first half a year of 2019. Riga Passenger port's turnover of passengers was 121.1 thousand, which is a $66.5 \%$ reduction (ferry transport in the route Riga - Stockholm was stopped, only allowing specific repatriation trips), Ventspils port -72.2 thousand passengers, $31.7 \%$ reduction, but Liepāja port -13.6 thousand passengers, $17.5 \%$ less than the previous year.

Despite the Covid-19 pandemic, starting from June 26 until August 16 of 2020 , for a time regular ferry transport was restarted in the route Riga Helsinki because during that time Finland was in the so-called "green list" that could be visited without the 14 day self-isolation that was mandatory after returning from many other countries.

In the period from 2012 till 2019, Latvian resident one day trip number notably increased (see Table 13), from which almost 80\% in 2012 and 95\% in 2018 were trips to neighbouring countries Lithuania and Estonia. ${ }^{9}$

Table 13. One day outgoing trips of residents of Latvia in 2012-2019

\begin{tabular}{|c|c|c|c|}
\hline Year & Trips, (thousands) & Expenses, (mill. Euro) & $\begin{array}{c}\text { Average spending per } \\
\text { day, (Euro) }\end{array}$ \\
\hline 2012 & 431.9 & 29.2 & 67.5 \\
\hline 2013 & 530.5 & 45.9 & 86.6 \\
\hline 2014 & 484.3 & 25.7 & 53.2 \\
\hline 2015 & 477.5 & 23.7 & 49.7 \\
\hline 2016 & 688.7 & 31.2 & 45.3 \\
\hline 2017 & 790.2 & 43.7 & 55.3 \\
\hline 2018 & 807.3 & 42.4 & 52.5 \\
\hline 2019 & 904.3 & 57.7 & 63.8 \\
\hline
\end{tabular}

Source: table made by authors based on Central Statistical Bureau of Latvia data

In contrast to overnight Latvian travellers, one day travellers more often chose to travel by motor vehicles: in $2019,88 \%$ drove a car, but only 5.7\% Latvian travellers took the bus.

In 2011, 275 tourism companies offered travel organisation services and served 302845 Latvian travellers who went abroad. Starting from

9 CSB unpublished data. 
2014, only those tourism companies were counted in the official statistics that offered tourism operator services, hence in that year there were only 169 and they served 439560 Latvian residents. In 2019, Latvia had 125 tourism operators that organised travel abroad for 335651 Latvian travellers, which makes up almost $23 \%$ of all the trips made in that year.

Turkey was the most popular package travel destination in the last decade, in 2019 attracting one fifth of all the organised Latvian travellers.

Table 14. The most popular package travel destinations for residents of Latvian (TOP 10) in $2011-2019$

\begin{tabular}{|r|l|l|l|l|l|l|}
\hline Year & \multicolumn{2}{|c|}{2011} & \multicolumn{2}{c|}{2015} & \multicolumn{2}{c|}{2019} \\
\hline & \multicolumn{1}{|c|}{ Country } & $\begin{array}{c}\text { Number of } \\
\text { travellers }\end{array}$ & \multicolumn{1}{|c|}{ Country } & $\begin{array}{c}\text { Number of } \\
\text { travellers }\end{array}$ & Country & $\begin{array}{c}\text { Number of } \\
\text { travellers }\end{array}$ \\
\hline 1. & Turkey & 51919 & Turkey & 50929 & Turkey & 72180 \\
\hline 2. & Germany & 18404 & Greece & 28149 & Greece & 33533 \\
\hline 3. & Spain & 18307 & Estonia & 22039 & Spain & 21414 \\
\hline 4. & Greece & 17227 & Spain & 19453 & Lithuania & 20320 \\
\hline 5. & Estonia & 14184 & Lithuania & 18452 & Estonia & 18924 \\
\hline 6. & BENELUX & 12772 & Italy & 16598 & Bulgaria & 16172 \\
\hline 7. & Italy & 11880 & Bulgaria & 15088 & Italy & 14978 \\
\hline 8. & Sweden & 10356 & Germany & 14715 & Poland & 6655 \\
\hline 9. & Lithuania & 9740 & Czech Republic & 12200 & Croatia & 6528 \\
\hline 10. & Finland & 8736 & Poland & 10313 & Germany & 5776 \\
\hline & Total & 302845 & Total & 348159 & Total & 335651 \\
\hline & Africa & 16045 & Africa & 26637 & Africa & 38881 \\
\hline & Asia & 11326 & Asia & 18326 & Asia & 16418 \\
\hline
\end{tabular}

Source: table made by authors based on Central Statistical Bureau of Latvia data

The Institute of Finances of "Swedbank" did a study in 2018, which shows that in 2013 at least half of Latvian residents could afford at least one week long annual travel vacation, but in 2018 that proportion reached $67 \% .{ }^{10}$ Still, information about the pending travel is acquired from relatives, friends and acquaintances; however social media is gaining importance since it is used by every third traveller, as well as travel service provider websites. Latvian residents, who have travelled abroad in the last three years, as the most important factors that impacted their travel purchases

\footnotetext{
${ }^{10}$ https://www.tvnet.lv/6763798/piecu-gadu-laika-latvija-strauji-audzis-iedzivotaju-skaitskas-var-atlauties-celot.
} 
indicate price (71\%) and reviews (61\%) (PTAC research, 2018). Trips are being planned more in advance, and special pre-sales with reduced prices of tourism agencies and tour operators are used more often. ${ }^{11}$

$21^{\text {st }}$ century travellers increasingly expect more personal treatment and understanding of their needs from tourism agencies. Travellers want quality leisure filled with new experiences, and there is a growing tendency to travel in small interest groups.

Now that Latvian travellers have gained more travel experience, they are more ready to be surprised while travelling; every third person says ${ }^{12}$ that they expect unplanned adventures and enjoy discovering attractions that have not been planned in advance. The trips of $21^{\text {st }}$ century are becoming more topical, for example, travelling to film sets of specific movies.

Even though occasionally, a travel agency experiences bankruptcy, for example, "Prieks tūre" and "Balta"; starting from 2019, travellers have better security because tourism agencies are licenced. Following tourism market development tendencies, travellers, who purchase package trips on the internet, are given the same level of security as those who buy package trips from travel agencies, furthermore, expanding traveller rights.

\section{Conclusion}

Outbound tourism of Latvia in the last three decades of the post-Soviet period clearly show travel transformation in destination choices, travel length, transportation choices, as well as rapid change in the amount of acquired traveller experience. Latvian residents go into the $21^{\text {st }}$ century as experienced tourists that can no longer be easily differentiated from tourists of other European countries.

\section{REFFERENCES}

Bicēna, B. (1995). Pa sliedēm no Rīgas līdz Vinnei. Ceḷotprieks, 1995. gada novembris. Birkavs, V., Dr. iur., ārlietu ministrs (1998). Latvija globalizācijas laikmetā/ Referāts konferencē Latvijas Zinātṇu akadēmijā, 1998. gada 22. septembris, Rīga. [Online] Awailable at:Pieejams: https:/www.vestnesis.lv/ta/id/50896.

Celmiṇš, J., Lidostas Rīga komercdirektora vietnieks (1994). Lidosta Rīga: vakar, šodien, rìt. Neatkarīgā Cinna, Nr. 103, 05.05.1994.

${ }^{11}$ https://sputniknewslv.com/Latvia/20170116/3660349/celosana-akcijas-turismaagenturas.html.

12 http://travelnews.lv/?pub_id $=78683$. 
Croes, R., Ridderstaat, J., Bak, M., Zientara, P. (2021). Tourism specialization, economic growth, human development and transition economies: The case of Poland, Tourism Management.

Detotto, C., Giannoni, S., \& Goavec, C. (2021). Does good governance attract tourists? Tourism Management, Volume 82.

Dienas Bizness, 2002. gada 24. jūlijs "Pieprasījums pēc čarterreisiem audzis dubulti”

Gavurova, B., Suhanyi, L., Rigelsky, M. (2020). Tourist spending and productivity of economy in oecd countries - research on perspectives of sustainable tourism, Entrepreneurship and Sustainability Issues, 8(1), pp. 983-1000.

Global Ranking - Visa Passport Index (2018). Henley \& Partners. [Online] Awailable at: Pieejams: https://www.henleypassportindex.com/passport.

Gozgor, G., Demir, E., (2018). The Effects of Economic Policy Uncertainty on Outbound Travel Expenditures, Journal of Competitiveness, 10 (3), pp. 5-15.

G̣iga, I. (1993). VIA BALTICA - visā garumā arvien vairāk pasažieru. Neatkarīgā Cīṇa, Nr. 92, 15.05.1993.

Impro ceḷojumu katalogs (2014).

Indāns, I. (1994). Ārvalstu vēstniecību darba apjomi vasarā pieaug. Diena, Nr. 218, 25.08.1994.

Jurisons, E. (1995). Pēkšṇi ceḷojumi pa Eiropu. Lauku Avīze, Nr. 11, 07.02.1995.

Kalve, A. (1994). Uz Kentuki lauvas šaut. Diena, Nr. 16, 20.01.1994.

Kusiṇa, L. (1996). Lidmašĩna viena, bet ērtības neierobežotas. Ceḷotprieks, 1996. gada februāris.

Labklājības Ministrija. Minimālā mēneša darba alga pa gadiem. Pieejams: http://www. Im.gov.lv/upload/darba_tirgus/minimala_darba_alga/minimala_menesa_darba_ alga.pdf.

Laikraksts Laiks, Nr. 60 1991. gada 27. jūlijs. [Online] Awailable at: Pieejams: http:// periodika.Iv/periodika2-viewer/view/index-dev.html?lang=fr\#panel:pa| issue:/p_000_xlak1991n060|article:DIVL564|query:LATVIA\%20TOURS | issueType:P.

Latvijas aviolīnijas ir grūtā situācijā. Latvijas Jaunatne, Nr. 36, 26.02.1992.

Lin, V. S., Liu, A., Song, H. (2015). Modeling and Forecasting Chinese Outbound Tourism: An Econometric Approach, Journal of Travel and Tourism Marketing, 32 (1-2), pp. 34-49 (SCOPUS).

Mackevičs, A., Veško, D. (2010). Intervija: Tez Tour pielāgojis ceḷojumus pašreizējām finansiālajām iespējām, BalticTravelnews.com. [Online] Awailable at: Pieejams: http://travelnews.lv/index.php?m_id=18288\&i_id=5\&pub_id=57216.

Pelūde, A., Neimanis, E. (1994). Ar vīzām bez vīzēm uz ārzemēm Kā nokḷūt ārzemēs un kā tikt atpakal Latvijā. Diena, Nr. 218, 19.09.1994.

Rutkovska, A. (2013). Ko tūrisma intensitāte liecina par ekonomiku. [Online] Awailable at: Pieejams: https://www.makroekonomika.lv/ko-turisma-intensitate-liecina-parekonomiku.

Starptautiskā lidosta R̄̄ga (2010). Gadagrāmata. [Online] Awailable at: Pieejama: https://www.riga-airport.com/par-lidostu/gadagramata. 
Voika, I. (1993). Noslēgusies Himalaju ekspedīcija. Latvijas Jaunatne, Nr. 274, 09.12.1993.

Vucina, G. (1992). Latvijā darbojas nu jau četras aviosabiedrības. Diena, Nr. 212, 10.11.1992.

Zālītis, R. (1995). Impro aicina ceḷot un rūpējas par bērniem. Diena, Nr. 10, 12.01.1995. Zeltiṇa, G. (1994). Žurnālistei Inai Eglītei raksta "Arī Sprīdītis gāja pasaulē. Pacietība ir galvenais mērs", Neatkarīgā Cinna, Nr. 280, 02.12.1994.

PTAC pētījums (2018). "Latvijas iedz̄ivotāju zināšanas par savām patērētāju tiesībām un pieredze ar nekvalitatīvu vai nedrošu preču/ pakalpojumu iegādi”.

LR CSP datubāze. [Online] Awailable at:Pieejams: https://www.csb.gov.lv/lv/statistika/db.

Tleuberdinova, A., Shayekina, Z., Salauatova, D., Pratt, S., (2021). Macro-economic Factors Influencing Tourism Entrepreneurship: The Case of Kazakhstan, Journal of Entrepreneurship, Volume 30, Issue 1, pp. 179-209.

Tūrisms Latvijā. Statistikas datu krājums - periodisks izdevums 1997.-2020. g., R.: CSP. 
https://doi.org/10.22364/hssl.29.1.03

\title{
LATVIAN-NORWEGIAN ECONOMIC RELATIONS 1918-1940
}

\author{
Viesturs Pauls Karnups ${ }^{2}$ \\ Faculty of Business, Management and Economics, \\ University of Latvia, Riga, Latvia
}

\begin{abstract}
This article provides an overview of Latvian-Norwegian economic relations in the interwar period. In the interwar period, economic relations between Latvia and Norwegian were mainly confined to foreign trade, although there were some investments in Latvia from Norway as well. Latvia declared its independence in 1918, however normal trade with Norway did not commence until 1920 after the end of the Latvian War of Independence. It ended with the occupation of Norway in 1940. Latvia's foreign trade in relation to Norway was regulated by the 1924 Commercial and Navigation treaty. Latvia's main imports from Norway in the interwar period were herrings, cotton cloth, agricultural and industrial machinery, treated hides, various types of metals and metal products, animal fats and fish oils, drive-belts, stones and wire, whilst Latvia's main exports to Norway were butter, meat, plywood, pit-props and boards, thread, linoleum, pulpwood, gypsum, paints and paint products, as well as radios. In general, trade and thus economic relations were of marginal significance to both countries in the interwar period due mainly to similarities in their economic structures and geographical distance.
\end{abstract}

Keywords: Latvia, Norway, economic relations, interwar period

\section{Introduction}

Until 1920 relations in general between Latvia and Norway was minimal, partly because up until 1917 Latvia was part of Tsarist Russia and partly because it was only at the end of 1919 that the National government had stabilised following the fall of the German-backed putschist Niedra government and the defeat of the German-supported Russian adventurer Bermont-Avalov. ${ }^{3}$ On 30 January 1920, an armistice between Latvia and Soviet Russia was signed with effect from 1 February. The final Peace Treaty was signed on 11 August 1920. The Latvian Republic was still not

1 A version of this article was presented at the Baltic Connections Conference 2021, April 29-21 2021, online, University of Helsinki, Finland.

2 Contact: Viesturs Pauls Karnups; viesturs.karnups@lu.lv; Faculty of Business, Management and Economics, University of Latvia, Riga, LV-1050, Latvia.

3 Spekke A. (1951), pp. 350-355. 
recognised de iure by any European state with the exception of Soviet Russia which itself was not recognised by any other state. Nevertheless, by late 1919, Norway had established a consulate in Riga.

Latvia was recognised de iure by Western Europe on 26 January 1921. This collective act of recognition, was accepted by Latvia as conferring final and unreserved de iure recognition on the part of all the states represented on the Allied Supreme War Council, namely, Belgium, the British Empire, France, Italy, and Japan. In the wake of this decision the consul for Norway in Riga visited the Latvian Foreign Office on 05 February 1921 to extend Norway's de iure recognition. ${ }^{4}$ In the interwar period, Norway had consulates in Riga, Liepāja and Ventspils.

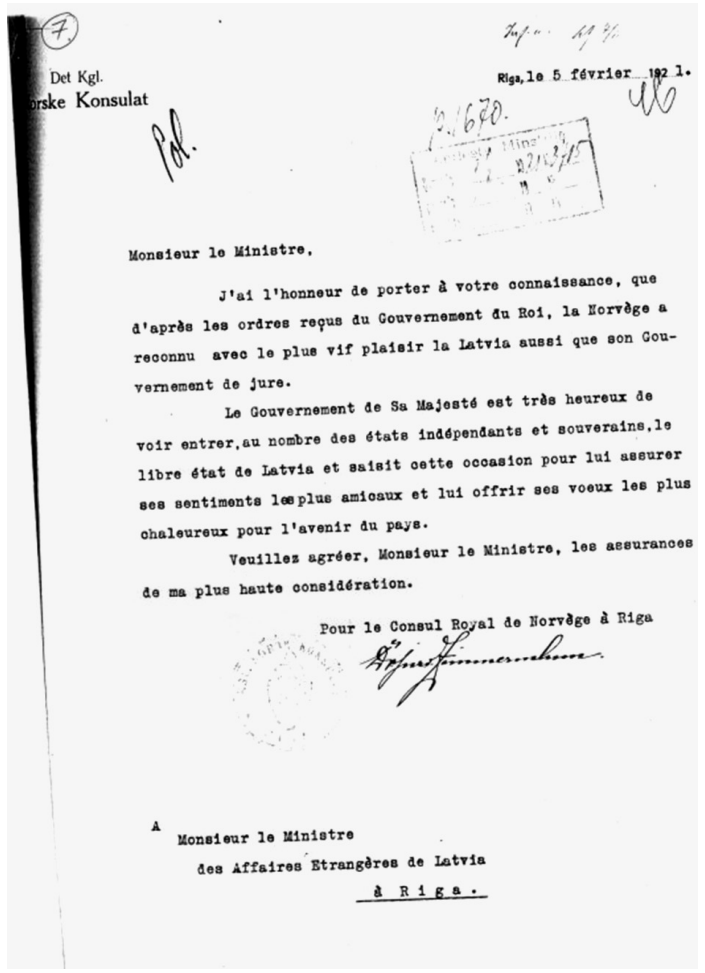

Figure 1. The note by the Consulate of Norway in Riga regarding the recognition of the State of Latvia and its government de iure, 05.02.1921

Source: https:/www.mfa.gov.lv/en/policy/baltic-sea-region/co-operation-among-the-baltic-andnordic-countries/found-in-the-archives/norway

4 LVVA, 2570. f., 3. apr., 1148., p. 46. 
Latvia had ten honorary consulates in Norway during the interwar period from Kristiansand in the south to Vardø in the north. The Generalconsulate of Latvia was in Oslo and throughout the interwar period, the general-consul was Arturs Vanags. From August 1919, he was appointed as the honorary consular agent for Latvia, and from May 1921, the honorary general-consul in Norway. From 1927, also an agricultural attaché to the Scandinavian countries. He worked very hard in fostering economic and cultural relations between Latvia and Norway. The activities of the General-consulate and the honorary consulates subordinate to him were suspended by the German invasion of Norway in April 1940.

Table 1. Selected economic indicators for Latvia and Norway in the interwar period

\begin{tabular}{|l|c|c|}
\hline & Latvia & Norway \\
\hline Population (millions) & $2(1939)$ & $2.9(1940)$ \\
\hline Share of urban population (\%) & $34.6(1935)$ & $28.5(1935)$ \\
\hline $\begin{array}{l}\text { GDP* per capita } \\
\begin{array}{l}\text { Average annual growth rate (GDP per capita) } \\
\text { 1920-1929 }\end{array}\end{array}$ & $4048(1938)$ & $4337(1938)$ \\
\hline $\begin{array}{l}\text { Average annual growth rates (GDP per capita) } \\
1929-1938\end{array}$ & 4.1 & 2.71 \\
\hline$\%$ share in GDP of agriculture and forestry & $39.2(1938)$ & 2.55 \\
\hline$\%$ share in GDP of industry & $20.5(1938)$ & $28(1939)$ \\
\hline
\end{tabular}

* GDP measured in 1990 International Geary-Khamis dollars

Sources: Darbiṇš, A. \& Vitin̦š, V. (1947); Broadberry. S. \& O’Rourke, K. H. (2016); The Northern Countries in the World Economy (1937); Mitchell, B.R (1978)

As can be seen from Table 1, despite a slightly larger population, Norway was less urbanised than Latvia in the interwar period. Nevertheless, although their economic structures were similar in many aspects (agriculture and forestry), Latvia had nearly 3 times larger \% share in GDP of agriculture and forestry than Norway. Norway also had a slightly larger $\%$ share in GDP of industry. It should be noted, that in 1939, industry and trade together with shipping represented over half (59\%) of Norway's GDP share..$^{5}$ Interestingly, Latvia's average annual growth rates both pre- and post the Great Depression were nearly twice that of Norway, whilst GDP per capita was only slightly higher in Norway. Nevertheless, Latvia was

5 Mitchell, B. R (1978), p. 430. 
classified by the League of Nations as a "less industrialised" country, whilst Norway was seen as an "industrialised" country. ${ }^{6}$

\section{Latvian-Norwegian Economic Relations 1919-1940}

Some Norwegian and Latvian trade was already been in existence prior to the Norwegian recognition of Latvia de iure. For example, in second half of 1919 (from 08 July to 31 December), Latvian exports to Norway totalled only 80 lats $^{7}$, but imports from Norway totalled 12931.8 lats. $^{8}$

In 1920, Norway was the first country to offer long-term credits to the infant Latvian State at a time when it had not been recognised de iure by Norway and when its financial resources were particularly low. The gesture of good will by the Norwegian government was based of course also on sound economic reasons. The Norwegian government was under pressure to clear its stocks of herrings purchased during and immediately subsequent to the First World War. Without large order sales in the near future, Statens Fiskecentral, in order to save on further upkeep and storage costs, would be forced to liquidate its old herring stocks by using them as feeding stuffs or handing them over to oil and fertiliser manufacturers. ${ }^{9}$ From the Latvian government's point of view the commodity credits were a godsend, especially when they were longterm (repayment by 01 January 1925) and could be secured with Treasury Bills instead of hard currency that was in short supply. However, the lure of quick profits turned an essentially bona fide commercial transaction into an object of a parliamentary inquiry and harsh criticism of the government (it became known as the "Herring Affair"). ${ }^{10}$ An expectation of selling excess barrels of herrings to Soviet Russia for a profit led to over-ordering, haste and waste for which, in the end, Latvia paid for dearly. Only the continuing needs of Soviet Russia allowed the Ministry of Supply to limit its losses and barter the herrings to Soviet Russia through the trade and exchange concessions on the Latvian-Soviet Russian border.

In the interwar years, Latvian and Norwegian economic relations was mainly confined to foreign trade and investment although other forms of economic relations such as tourism were also important.

6 Industrialisation and Foreign Trade (1945), pp. 26-27.

7 Latvian roubles in 1919-1922 have been converted to Latvian lats in accordance with the rate set by the State Statistical administration -1 lat $=50$ roubles.

8 Ekonomists, 1920, No. 3, p. 90-91.

9 'Norway in 1920' (1921), p. 19.

${ }^{10}$ For detailed account of the Herring Affair see Karnups (2004), pp. 222-228. 
Latvia's foreign trade in the interwar was based in large measure on a system of commercial and trade treaties. By 1929, Latvia had concluded commercial treaties with all important European states (except Spain) including a Commercial and Navigation Treaty between Latvia and Norway in 1924. They provided the regulatory framework within which were stated the obligations undertaken by Latvia in its foreign trade relations with its trading partners up to 1931. All these treaties contained the Most Favoured Nation (MFN) principle, as well as in practically all, the Baltic and Russian clause. The Baltic and Russian Clause stipulates that the priority rights and privileges, allowed to Estonia, Finland, Lithuania, and Russia, may not be made applicable to other contracting states by virtue of the most-favoured-nation principle.

Latvia began negotiations on a trade agreement with Norway in $1921 .^{11}$ In 1923, in the context of the negotiations on the trade agreement, there was an echo of the herring affair, when the Latvian envoy in Finland, Kārlis Zariňš, received a copy of the letter from his Norwegian counterpart, dated 24 March 1920, signed by F. Grosvalds. ${ }^{12}$ The letter to the Norwegian Ministry of Foreign Affairs stated that while the herring purchase agreement of 17 March 1920 was in force, Latvia granted Norway most favoured nation status. The Norwegian ambassador to Finland stated that, on the basis of this letter, there was nothing to rush with the conclusion of trade agreements, as Norway already had its most favoured nation status for some time. ${ }^{13} \mathrm{~K}$. Zarinš was not sure if the Ministry of Foreign Affairs of Latvia knew about the existence of such a letter. The Commercial and Navigation Treaty between Latvia and Norway was finally signed on 14 August 1924 and came into force on 10 June 1925. ${ }^{14}$ It contained the Baltic and Russian clause, as well as a reciprocal clause from the Norwegian side in relation to states bordering Norway [Sweden and Finland], Denmark and Iceland.

\section{Latvian-Norwegian Trade 1920-1940}

As noted previously, some Latvian-Norwegian trade had occurred in 1919. The value of Latvian imports from and exports to Norway can be seen in the Figure 2.

\footnotetext{
${ }^{11}$ LVVA, 2570. f., 13. apr., 131. 1., p. 3.

12 Ibid., p. 10.

13 Ibid., p. 9.

${ }^{14}$ Likumu un Ministru kabineta noteikumu krājums. 1925. gads. - Rīga: Kodifikācijas nodaḷas izdevums, 1925, pp. 192.-198.
} 


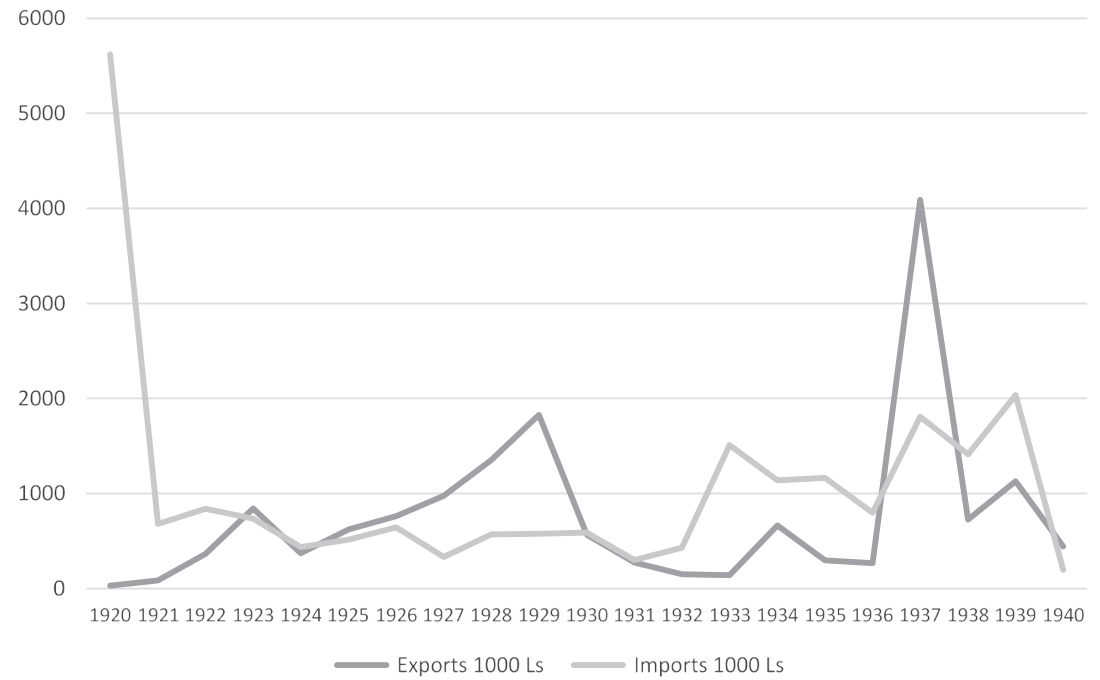

Figure 2. Latvia-Norwegian Imports and Exports 1920-1940

Sources: Latvijas Statistiskā gada grāmatas [Latvian Statistical Yearbooks]. 1921-1939; Mēneša Biḷetens Nr. 10, oktobris 1939 [Monthly Bulletin, No. 10, October 1939; Historisk Statistikk 1968. - Oslo: Statistisk Sentralbyrå, 1969.

As Figure 2 shows, from a high start imports decreased substantially in the interwar period. The signing of the trade agreement in 1924 did not stimulate imports and it was not until the 1930s that imports increased significantly reaching a peak in 1939. Exports, on the other hand, increased more slowly with a peak in 1929 with a value of nearly two million lats. Both imports and exports fell with Great Depression, although imports recovered fairly quickly, starting to rise from 1932 and reaching their peak in 1939. Exports on the other hand, continued at low level until the devaluation of the Lat in $1936 .{ }^{15}$ The sharp rise in exports to Norway in 1937 is usually explained by the short-term effect of the devaluation. Generally, exports exceeded imports in the 1920s, whilst imports exceeded exports (except for 1937) in the 1930s.

${ }^{15}$ See Karnups (2012) for a discussion of the effects of the 1936 Lat devaluation on Latvia's foreign trade. 


\section{Latvian Exports to Norway}

Latvia's main exports to Norway were Timber and timber products, Gypsum and gypsum products, Flax threads, Linoleum, Radios, Paints, inks and paint compounds, and Paper and paper products (See Table 2).

Table 2. Latvia's Main Exports to Norway (1921-1940)

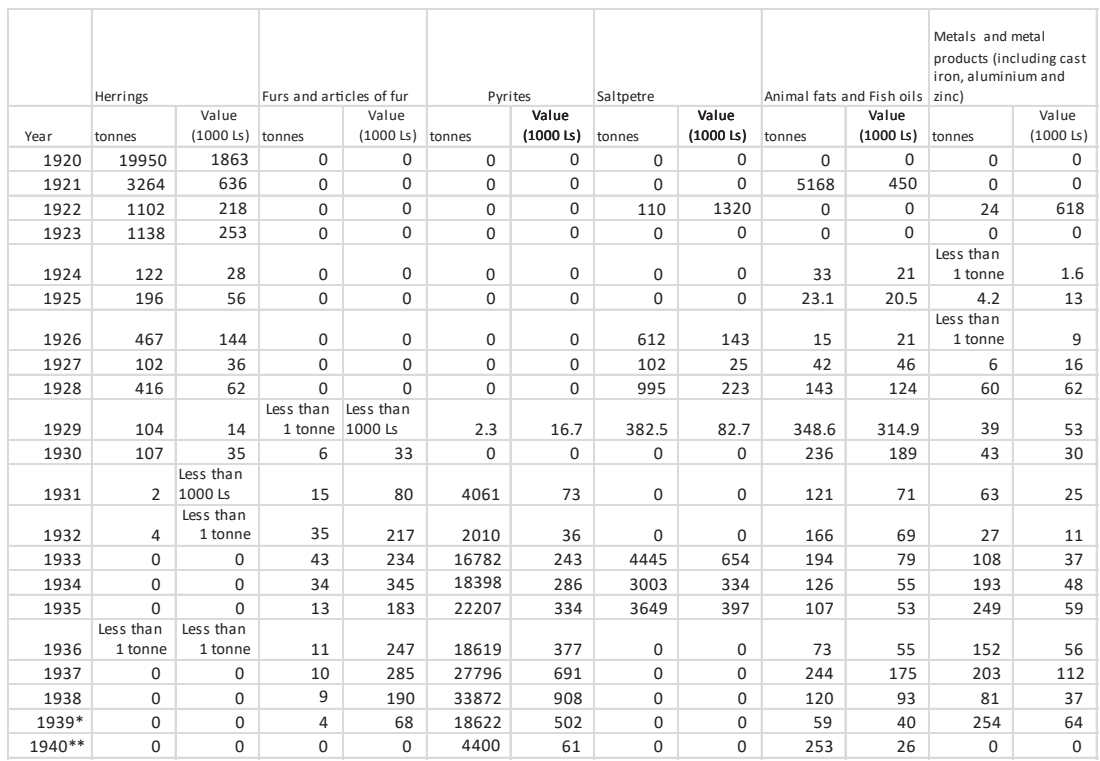

* January-August 1939 (with commencement of WWII, Latvia ceased publication of detailed foreign trade statistics)

*** January-August 1940 (Norwegian statistics)

Sources: Latvijas Statistiskā gada grāmatas [Latvian Statistical Yearbooks]. 1921-1939; Latvijas ārējā tirdzniecība un transits - 1924-1939. [Latvian Foreign Trade and Transit. 1924-1939.]; Mēneša Biḷetens Nr. 10, oktobris 1939 [Monthly Bulletin, No. 10, October 1939; Historisk Statistikk 1968. - Oslo: Statistisk Sentralbyrå, 1969.

Timber and timber products were a steady if fluctuating export product to Norway reaching a peak in 1929, with another large shipment in 1937. The largest export in terms of volume if not value was Gypsum and gypsum products, which only commenced in the 1930s and reached a peak of 96 thousand lats in 1937. Flax threads (also to minor extent flax) were a steady, but small part of exports as were Paper and paper products. Paints, inks, and paint compounds only commenced in the 1930s and were a small, but important part of exports. 
Linoleum was an important export to Norway in the 1920s. As noted in Chapter ..., the linoleum plant was closed in 1930 and the last shipment of linoleum to Norway was in the same year. Its place was to a certain extent taken up by the export of radios in the 1930s, the value of which exceeded that of the other export products reaching a peak of 405 thousand lats in 1938. Latvian-made radios were popular throughout the Nordic region.

Latvia also exported small quantities of rye, eggs, butter, meat and other food products, textiles, and electrical goods in the interwar period.

\section{Latvian Imports from Norway}

Latvia's main imports from Norway were Herrings, Furs and articles of fur, Pyrites, Metals and metal products, Saltpetre and Animal fats and Fish oils. The amounts and value of Latvia's main imports imported from Norway in the interwar period are shown in Table 3.

Table 3. Latvia's Main Imports from Norway (1920-1940)

\begin{tabular}{|c|c|c|c|c|c|c|c|c|c|c|c|c|}
\hline \multirow[b]{2}{*}{ Year } & \multicolumn{2}{|c|}{$\begin{array}{l}\text { Timber and timber } \\
\text { products }\end{array}$} & \multicolumn{2}{|c|}{$\begin{array}{l}\text { Gypsum and gypsum } \\
\text { products }\end{array}$} & \multicolumn{2}{|c|}{ Flax threads } & \multicolumn{2}{|l|}{ Linoleum } & \multicolumn{2}{|c|}{$\begin{array}{l}\text { Paints, inks and paint } \\
\text { compounds }\end{array}$} & \multicolumn{2}{|c|}{$\begin{array}{l}\text { Paper and paper } \\
\text { products }\end{array}$} \\
\hline & tonnes & $\begin{array}{l}\text { Value } \\
(1000 \text { Ls })\end{array}$ & tonnes & $\begin{array}{c}\text { Value } \\
(1000 \text { Ls })\end{array}$ & tonnes & $\begin{array}{l}\text { Value } \\
\text { (1000Ls) }\end{array}$ & tonnes & $\begin{array}{l}\text { Value } \\
(1000 \text { Ls })\end{array}$ & tonnes & $\begin{array}{l}\text { Value } \\
(1000 \text { Ls) }\end{array}$ & tonnes & $\begin{array}{l}\text { Value } \\
(1000 \text { Ls) }\end{array}$ \\
\hline 1921 & 7365 & 135 & 0 & 0 & 0 & 0 & 0 & 0 & 0 & 0 & 0 & 0 \\
\hline 1922 & 2079 & 217 & 0 & 0 & 0 & 0 & 0 & 0 & 0 & 0 & 0 & 0 \\
\hline 1923 & 8326 & 638 & 0 & 0 & 0 & 0 & 5 & 6 & 0 & 0 & $\begin{array}{l}\text { Less than } \\
1 \text { tonne }\end{array}$ & $\begin{array}{l}\text { Less than } \\
1000 \text { Ls }\end{array}$ \\
\hline 1924 & 550 & 43 & 0 & 0 & 0 & 0 & 6 & 8 & 0 & 0 & 0 & 0 \\
\hline 1925 & 2381 & 313 & 0 & 0 & 0 & 0 & 7 & 9 & 0 & 0 & 43 & 25 \\
\hline 1926 & 18 & 7 & 0 & 0 & 4 & 18 & 170 & 268 & 0 & 0 & 25 & 11 \\
\hline 1927 & 3388 & 232 & 0 & 0 & 37 & 168 & 255 & 447 & 0 & 0 & 37 & 168 \\
\hline 1928 & 17014 & 837 & 0 & 0 & 8 & 36 & 106 & 177 & 0 & 0 & 8 & 26 \\
\hline 1929 & 21270 & 1009 & 0 & 0 & 77 & 293 & 233 & 352 & 0 & 0 & 10 & 5 \\
\hline 1930 & 64 & 33 & 5125 & 39 & 61 & 225 & 109 & 162 & 0 & 0 & 61 & 225 \\
\hline 1931 & 0 & 0 & 3310 & 28 & 25 & 63 & 0 & 0 & 0 & 0 & 25 & 63 \\
\hline 1932 & 117 & 27 & 4515 & 33 & 31 & 76 & \multicolumn{2}{|c|}{ Radios } & 0 & 0 & 31 & 76 \\
\hline 1933 & 3190 & 51 & 5685 & 36 & 9 & 19 & 0 & 0 & 0 & 0 & 9 & 19 \\
\hline 1934 & 778 & 15 & 18396 & 95 & 15 & 28 & 0 & 0 & 108 & 42 & 15 & 28 \\
\hline 1935 & 0 & 0 & 5383 & 26 & 6 & 12 & 0 & 0 & 97 & 34 & 6 & 12 \\
\hline 1936 & 0 & 0 & 9151 & 53 & 69 & 123 & $\begin{array}{l}\text { Less than } \\
1 \text { tonne }\end{array}$ & 3 & 148 & 59 & 69 & 123 \\
\hline 1937 & 80155 & 3462 & 15425 & 96 & 11 & 29 & 24 & 251 & 137 & 96 & 77 & 24 \\
\hline 1938 & 0 & 0 & 12479 & 83 & 4 & 15 & 47 & 405 & 138 & 87 & 57 & 19 \\
\hline $1939^{*}$ & 0 & 0 & 6750 & 45 & 34 & 90 & 8 & 94 & 127 & 86 & 0 & 0 \\
\hline $1940 * *$ & 0 & 0 & 1130 & 47 & $\begin{array}{l}\text { Less than } \\
1 \text { tonne }\end{array}$ & $\begin{array}{l}\text { Less than } \\
1000 \text { Ls }\end{array}$ & $\begin{array}{l}\text { Less than } \\
1 \text { tonne }\end{array}$ & 2 & $\begin{array}{l}\text { Less than } \\
1 \text { tonne }\end{array}$ & 14 & $\begin{array}{l}\text { Less than } \\
1 \text { tonne }\end{array}$ & 6 \\
\hline
\end{tabular}

* January-August 1939 (with commencement of WWII, Latvia ceased publication of detailed foreign trade statistics)

*** January-August 1940 (Norwegian statistics)

Sources: Latvijas Statistiskā gada grāmatas [Latvian Statistical Yearbooks]. 1921-1939; Latvijas ārējā tirdzniecība un transits - 1924-1939. [Latvian Foreign Trade and Transit. 1924-1939.]; Mēneša Biḷetens Nr. 10, oktobris 1939 [Monthly Bulletin, No. 10, October 1939; Historisk Statistikk 1968. - Oslo: Statistisk Sentralbyrå, 1969.

In the 1920s, herrings were the most important and main import from Norway to Latvia. The largest volume and value of herrings was imported 
in 1920 as part of the Herring affair noted above. The impact of the Great Depression drastically reduced the import of herrings and this reduction was finalised with Latvia's new trade agreement with the United Kingdom in 1934. The agreement was based on a reciprocity (mutual obligations, compliance) principle. The agreement spelled out Latvia's obligation to import from the UK various commodities, in this case herrings from Scotland, because the British objective was to improve the negative balance of trade with Latvia. Thus, imports of herrings from Norway practically disappeared from Latvia's import structure.

Animal fats and fish oils were a steady, but small part of imports as were Metals and metal products (including cast iron, aluminium and zinc). The import of furs and articles of fur began in the 1930s and became a small, but steady part of imports. Saltpetre was an important import in the late 1920s and early 1930s, but disappeared as other sources of saltpetre were found (mainly Germany due the clearing agreement between the two countries). Latvia imported pyrites from Spain in large quantities in the late 1920s, but this was discontinued due to the lack of a trade agreement (and Spain's internal problems in the 1930s) and the product was imported from Norway with which Latvia had such an agreement. It was the largest import item both in terms of volume and value in the 1930s, reaching a peak of 33872 tonnes and 908 thousand lats in 1938.

During the interwar period Latvia also imported a whole range of Norwegian goods in various quantities including live animals (sheep), agricultural and industrial machinery, textiles and textile products, paving stones, and instruments, as well as small quantities of other goods.

\section{Norwegian investments in Latvia 1925-1939}

Foreign capital in Latvia was mainly invested in banking, industry, transport, and trade. By 1927, over $60 \%$ of the equity capital of all Latvian joint-stock banks ${ }^{16}$ was foreign owned, while foreign capital comprised $27.8 \%$ of aggregate capital in insurance, $33.9 \%$ in trade (commerce), $63.1 \%$ in transport and about 50\% in industry. ${ }^{17}$ Many investors hoped that from Latvia they would be able to expand in the huge Russian market. Figure 3 provides an overview of Norwegian investments in the interwar period.

\footnotetext{
${ }^{16}$ For a brief overview of banking in Latvia in the interwar period see Hiden (2000), pp. 133-149.

17 The Latvian Economist (1928), p. 24.
} 


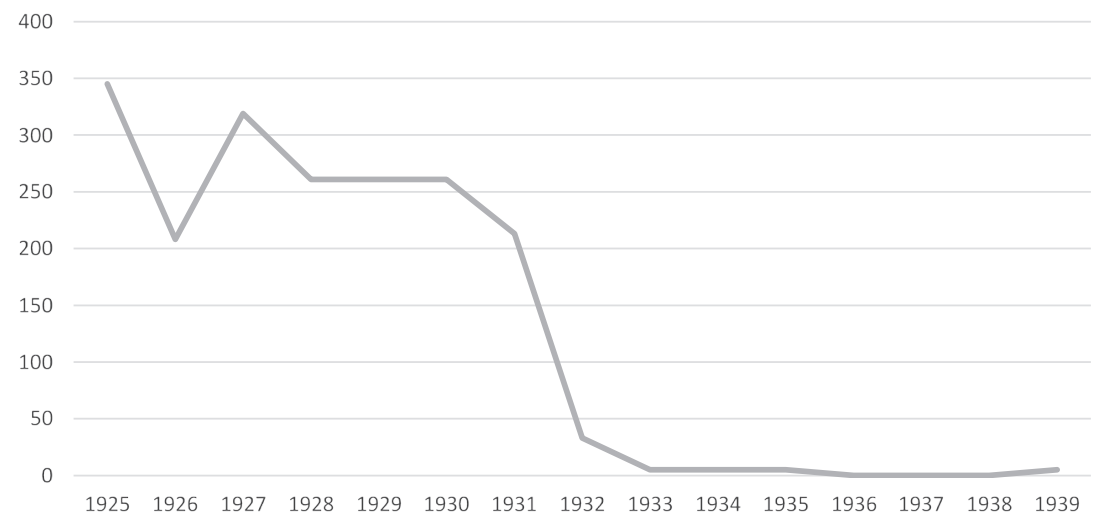

Figure 3. Norwegian investments in the Company Capital of Latvian Undertakings (as at 1 January). 1925-1939 (1000 lats)

Sources: Latvijas Statistiskā gada grāmata. 1929, 1939 [Latvian Statistical Yearbooks 1929, 1939]; Statistikas tabulas [Statistical Tables] 1940

The peak year for Norwegian investments in Latvia was 1925, when investments totalled 345000 lats. Norwegian investments were mainly in the timber industry sector (43.5\% of total Norwegian investments in 1925), followed by transport (20.9\%), and some other minor investments.

The onset of the Great Depression marked a dramatic reduction in the value of Norwegian investments in Latvia from 1930. Norway had withdrawn its capital from the timber industry by 1933 and only a small investment in transport (5000 lats) remained. From the peak in 1925, Norwegian investments were reduced to zero by 1936. Investment in transport returned in 1939 (again only 5000 lats).

An echo of this investment occurred post-war. Despite the fact that Norway never officially recognised the incorporation of Latvia into the USSR, they were not above submitting a claim for compensation to the USSR for nationalised Norwegian property in Latvia and the other Baltic States, for which they received $1 / 2$ million NOK compensation in $1959 .{ }^{18}$

${ }^{18}$ They did agree orally that the claim and subsequent agreement was not to be considered a de iure recognition of the incorporation of the Baltic States into the USSR after the USSR had protested against a written statement to that effect (see Kyn, P. (1998), p. 233.). 


\section{Latvia and Norway and the beginning of WWII ${ }^{19}$}

After September 1939, foreign trade became Latvia's weakest point. A great deal of what happened in foreign trade was beyond the control of Latvia and was a consequence of the war. ${ }^{20}$ The commencement of the war effectively closed the Baltic Sea region to British and allied shipping as it was clear that the Royal Navy would not enter the Baltic Sea to offer protection against German warships. In September 1939, the Admiralty closed both the Baltic and Mediterranean Seas to the British merchant marine. ${ }^{21}$ The British suggested that the Baltic States organise their foreign trade in their own ships to Sweden via the territorial waters of the Baltic States, Finland, and Sweden. Swedish and Norwegian railways could then take them to Norwegian ports on the Atlantic coast for transhipment to Britain. ${ }^{22}$

Despite many official announcements that trade with Britain had ceased (mainly to placate the Germans) some minor trade continued through the Norwegian ports. The Consul General of Latvia in Norway, A. Vanags, in reply to a letter from the Latvia Foreign Ministry on 2 January 1940 noted that if the bill of lading is made out for goods as transit goods through Norway then the Norwegians would not detain them. ${ }^{23}$ Swedish transit data for the period confirms that the preferred route for Latvian agricultural exports between September 1939 and April 1940 was to Swedish ports, by rail to Norwegian ports and thence to Britain. ${ }^{24}$ Imports came by the same route or directly to Swedish ports (especially Gothenburg) in neutral ships.

With the commencement of the German offensive in the West, all vestiges of trade with Britain disappeared. The rapid occupation of Denmark and Norway in April 1940 put paid to any thoughts of further utilising the Sweden-Norway transhipping route or even the often discussed, but seldom used route via the coastal waters of Sweden, Denmark, and Norway. On 17 June 1940, Latvia was occupied by the Soviet Union.

${ }^{19}$ For a detailed analysis of this period see Karnups, V. P. (2011).

20 For a comprehensive overview of Latvian foreign trade as a whole for 1939/1940, see Stranga A. "Latvijas ārējā tirdzniecība 30. gadu nogale" [Latvian Foreign Trade of the End of the 1930s] / Latvijas Vēsture Nos. 1993/4, 1994/1, 1994/3, 1995/1, 1995/2 and $1995 / 3$.

${ }^{21}$ LVVA, 2574. f., 4. apr., 7499. 1., p. 141.

${ }^{22}$ Andersons, E. (1984) p. 295.

${ }^{23}$ LVVA, 2575.F., 13. apr., 2. 1., p. 48.

${ }^{24}$ National Archive in Stockholm, Utrikesdepartementet, 1920 års dossier - system, H 2606, and National Archives in Arninge, Sweden, Statens handelskommission, 1939 års, statistiska avdelningen, vol. 25. 


\section{Conclusion}

In the interwar years, Latvian and Norwegian economic relations was mainly confined to foreign trade and investment although other forms of economic relations such as tourism were also important. Nevertheless, despite geographical proximity and the advantage of shorter sea routes than to Britain, the fact of similar major export products made significant inter-regional trade between Latvia and Norway unprofitable.

In 1929, when Latvian foreign trade reached its pre-Depression peak, Latvian exports to Norway made up $0.67 \%$ of total Latvian exports, and Norwegian imports made up $0.16 \%$ of total Latvian imports. However, in 1937, when Latvian foreign trade reached its post-Depression peak, exports to Norway were $1.6 \%$ of total Latvian exports, and imports from Norway were only $0.8 \%$ of total Latvian imports. One suspects that the figures from the point of view of Norway would be significantly less. In other words, trade and thus economic relations were of marginal significance to both countries in the interwar period.

It is interesting to note that in 2019, Latvian exports to Norway totalled 484.0 million EUR or $2.6 \%$ of total Latvian exports (mainly metals and metal products, food industry products, paper and paper products, timber, and timber products). Whilst imports from Norway totalled 111.4 million EUR or $0.6 \%$ of total Latvian imports (mainly mineral products, animal husbandry products, timber and timber products, machinery and electrical goods, and metals and metal products). At the end of 2019, total Norwegian FDI in Latvia was 458 million EUR, whilst total Latvian FDI in Norway was 14 million EUR. There were some 258 Norwegian companies registered in Latvia in 2019 (service, retail, manufacturing, and other industries) with a total invested equity capital of 326.3 million EUR. ${ }^{25}$

\section{REFERENCES}

'Norway in 1920' (1921), Norwegian Trade Review, No. 2,Trade Intelligence Bureau of Norway.

Andersons, E. (1984), Latvijas Vēsture 1920-1940. Ārpolitika II [History of Latvia 1920-1940. Foreign Affairs Vol. 11] - Stockholm: Daugava.

Broadberry, S. \& O'Rourke, K. H. (2016), The Cambridge Economic History of Modern Europe, Vol. 2: 1870 to the Present, Cambridge: Cambridge University Press.

Darbiṇš, A. \& Vìtiňš, V. (1947), Latvija: Statistisks pārskats [Latvia: A Statistical Overview], Germany: P. Mantinieka \& E. Ķiploka Apgadi.

${ }^{25}$ Data from LIAA [Latvian Investment and Development Agency], http://eksports.liaa. gov.lv/files/liaa_export/attachments/2020.03_LV_Norvegija_ekon_sad.pdf [Accessed 23.06.2020]. 
Finanču un kredita statistika 1939. g [Finance and Credit Statistics] (1939), Rīga: Valsts statistiskā pārvalde.

Historisk Statistikk 1968 (1969), Oslo: Statistisk Sentralbyrå.

Industrialisation and Foreign Trade (1945), Geneva: League of Nations (Ser.L.o.N.P. 1945.II.A.10).

Karnups, V. P., (2004), Latvian and Norwegian Economic Relations - the Herring Affair 1920, in International Conference Proceedings 'Enlargement of the European Union in the Baltic Sea Region: Social and Economic Challenges and Opportunities, Rìga: University of Latvia.

Karnups, V. P. (2011), Latvian Economic Links to Great Britain via Scandinavia 1939/40, in Humanities and Social Sciences Latvia, Vol. 19, Issue 1, (Summer-Autumn 2011), pp. 4-28.

Karnups, V. P. (2012), The 1936 Devaluation of the Lat and its Effect on Latvian Foreign Trade, in Humanities and Social Sciences Latvia, Vol. 20, Issue 1 (Winter-Spring 2012), pp. 49-62.

Kyn, P. (1998), Aspects of Recognition. Denmark's Relations to the Baltic States and Non-Recognition 1940-1991. / Hovi, K. (ed.) Relations between the Nordic Countries and the Baltic States in the XX Century. / Turku: University of Turku, 212.-255. Ipp.

Latvijas ārējā tirdzniecība un tranzits - 1924-1939. [Latvian Foreign Trade and Transit. 1924-1939.] Rīga: Valsts Statistiskā Pārvalde.

Latvijas Statistiskā gada grāmatas [Latvian Statistical Yearbooks]. 1921-1939. - Rīga: Valsts Statistiskā Pārvalde.

LVVA, Latvijas Valsts Vēstures arhīvs [Latvian State Historical Archives].

Mēneša Biḷetens Nr. 10, oktobris 1939 [Monthly Bulletin, No. 10, October 1939].

Mitchell, B. R. (1978), European Historical Statistics 1750-1970, London: Macmillan. Spekke, A. (1951), History of Latvia. An Outline, Stockholm: M.Goppers (Zelta Ābele). Statistikas tabulas [Statistical Tables] - Rīga: Latvijas PSR Tautsaimniecības Statistikas pārvalde, 1940.

Stranga, A. "Latvijas ārējā tirdzniecība 30. gadu nogale" [Latvian Foreign Trade of the End of the 1930s], in Latvijas Vēsture, 1993/4, 1994/1, 1994/3, 1995/1, 1995/2 and $1995 / 3$.

The Latvian Economist (1928), Rīga: Ministry of Finance.

The Northern Countries in the World Economy, (1937), Finland: Delegations for the Promotion of Economic Co-operation Between the Northern Countries. 
https://doi.org/10.22364/hssl.29.1.04

\title{
THE ROLE OF EXPENDITURE ON RESEARCH AND DEVELOPMENT (R\&D) IN PROMOTING ECONOMIC GROWTH AND COMPETITIVENESS
}

\section{Sandra Jekabsone ${ }^{1}$}

Faculty of Business, Management and Economics, University of Latvia, Riga, Latvia

\section{Ilze Sproǵe}

Faculty of Business, Management and Economics, University of Latvia, Riga, Latvia

\section{Solvita Kristone}

Faculty of Business, Management and Economics, University of Latvia, Riga, Latvia

\begin{abstract}
Development of science and research is fundamental for economic growth, as well as the competitiveness of a country. Taking into account the potential decrease of EU funds financing and the limited amount of Latvian national financing, it is necessary to ensure that the efficiency of the use of financing is maintained and raised further. The aim of the study is to evaluate the impact of the EU funds funding activities of 2007-2013 and 2014-2020 on science, research and innovation support activities of Latvian research institutions, as well as the sustainability of the results obtained within the support activities, taking into account the measures planned to support research, development and innovation during the programming period of EU funds 2021-2027.

The results of the research show that expenditure in research and development $(R \& D)$ in Latvia is small and dependent on European Structural Funds (currently R\&D investments are mainly attracted by EU funds), which is not a sustainable solution for $\mathrm{R} \& \mathrm{D}$ development, considering that this financing and its availability are periodic and in the future. This requires consistent long-term public and private (business) $\mathrm{R} \& \mathrm{D}$ investment.
\end{abstract}

Keywords: Latvian scientific institutions (SI), research and development (R\&D), innovation, competitiveness.

1 Contact: Sandra Jekabsone; sandra.jekabsone@lu.lv; Faculty of Business, Management and Economics, University of Latvia, Riga, LV-1050, Latvia. 


\section{Introduction}

Developments in science, technology and innovation are major drivers of change in modern societies. R\&D is one category of spending that develops and drives new technologies. From the perspective of competitiveness, private sector firms are prone to focus their $R \& D$ on "applied" projects and many government-sponsored technological advances have been instrumental in driving economic growth and rising living standards (Priede, 2013). Unfortunately the dynamics of competitiveness indicators show that the model of the Latvian economy has not changed and the benefits of low cost competitive advantage still remains. In order to ensure the development of the Latvian science system, to improve the quality and competitiveness of science, as well as to plan investments within the EU funds programming period 2021-2027, it is important to evaluate the efficiency of investments made so far in certain Latvian scientific institutions.

The aim of the study is to evaluate the impact of the EU funds funding activities of 2007-2013 and 2014-2020 on science, research and innovation support activities of Latvian research institutions, as well as the sustainability of the results obtained within the support activities, taking into account the measures planned to support research, development and innovation during the programming period of EU funds 2021-2027.

To achieve the aim of the research the following tasks were determined:

1) to look at the amount of EU funding in the last two programming periods to support science, research and innovation;

2) to evaluate its impact on the functioning of Latvian scientific institutions (HEI); 3) to look at the sustainability of the results obtained within the support activities.

The article analyses the impact of ten EU-funded activities on the key characteristics of the Latvian science and innovation system - human resources, collaborative networks, internationalisation of science, collaboration with business, research infrastructure, quality of research and its effectiveness.

Scientific methods used in the research: analysis of scientific literature, empirical analysis, grouping, comparison and decomposition of data.

Theoretical and methodological basis of the study is specialised economic literature and foreign scientific research papers, including studies by economists of IMF, OECD and European Commission, Legislation of the Republic of Latvia, as well as EUROSTAT and CSB statistical data. 


\section{Theoretical background}

Economic growth, productivity and its causal relationships have for years served as a basis for discussion among economists. Many authors emphasise importance of research and innovation in economics growth (for example, Lopez-Rodriguez \& Martinez-Lopez, 2017 etc.). Today's understanding of the key drivers of economic growth dates back to at least 1911, when Schumpeter argued that economic growth depends on innovation through competition between firms (Schumpeter, 1982). Innovation and the subsequent technological progress in economic growth models have become increasingly important over time. In the neoclassical or Solov model of economic growth, showed that economic growth in the long run depends on the development of technologies that allow more efficient use of labour and capital, increasing their productivity (Solov, 1956). Unfortunately, in Solov model, it does not provide an explanation for technological progress, prompting many economists to ask additional questions. Lucas, Romers and others complemented the neoclassical model with investment in $R \& D(R \& D)$, in other words, the accumulation of knowledge and human capital as a determinant of technological progress, helping to better understand observed differences in growth between countries (Romers, 1990).

According to one of the most significant research work in their field (Koe and Helpman, 1995), there are several channels through which R\&D investment increases labour productivity. Firstly, by enabling the creation of new products and services by making more effective use of existing capital. Second, it makes it easier to adopt more advanced technologies used in other countries, thus improving the quality of capital. Thirdly, through direct learning and self-development of new technologies and indirectly through the import of products and services using the latest technologies. Similarly, Griffith notes that investment in R\&D has two roles - to promote new innovation and to encourage imitation of other innovations (Griffith, 2002). Imitation is important to promote the so-called income convergence process in countries that are not innovation leaders and ranked lower in the world in terms of income. By actively investing in $R \& D$, one gains knowledge that can be used to understand and apply breakthroughs and advanced technologies. In addition, the farther away a country is from the forefront of innovation, the higher the productivity growth through R\&D investment. Conversely, as a country moves closer to the advanced economies, the return on each euro invested in $R \& D$ is gradually decreasing (the effect of falling marginal yield). 


\section{Research results and discussion}

Productivity growth has fallen over the past two decades, especially since the 2008 global financial crisis. This trend, combined with low or declining multi-factor productivity growth in several countries and sectors, has raised concerns about the ability of research and innovation activities to support economic growth and social wellbeing. Scholars continue to debate the reasons for the slowdown. Some point to slower rates of innovation, which is the root of productivity. Others point to the historical time lag between innovation and its impacts on productivity (OECD, 2018).

In such a situation ensuring economic growth in the world, including Latvia, is even more acute. Challenges related to stimulating productivity, mainly through:

- human capital and technological progress,

- making more effective use of the opportunities offered, and

- investment in research and development.

This applies equally to the private and public sectors. One needs to create a coordinated (including a strong internal one) monitoring systems of strategic public assets, in particular non - financial assets coherence and complementarity of objectives; a more efficient business environment and wider public good.

A key challenge in boosting productivity will be the ability of a country to find effective solutions (on resource management and systematisation) with respect to the subsequent national information system integration, by making e-services more widely available, not only making them more user-friendly, but also allowing a significant proportion of public sector employment to be redirected to other economies industries.

The Commission for Sustainable Development, agreed in 2014 on the issue and in-depth research in four thematic directions were identified as the main bottlenecks in Latvia in the context of economic competitiveness:

- offsetting the quantitative decline in the number of people by the quality of human resources increase;

- closer links between science and business;

- creating a fair business environment; and

- efficient and sustainable use of natural resources and public assets.

Investment in Research and Development (R\&D) fosters new innovation and fosters the innovation of others, thereby increasing overall productivity. By actively investing in $R \& D$, one gains knowledge that can be used to understand and apply breakthroughs and advanced technologies. Investing in $R \& D$ thus contributes to the growth of knowledge, which contributes to competitiveness and added value. In addition, the farther away a country is from the forefront of innovation, the higher the productivity 
growth through $R \& D$ investment. Latvia is in the penultimate position among the EU countries in terms of R\&D financing against GDP. Low R\&D investment may have a negative impact on Latvia's long-term growth, limiting opportunities to develop knowledge and technology-intensive industries and achieve higher productivity (see Figure 1).

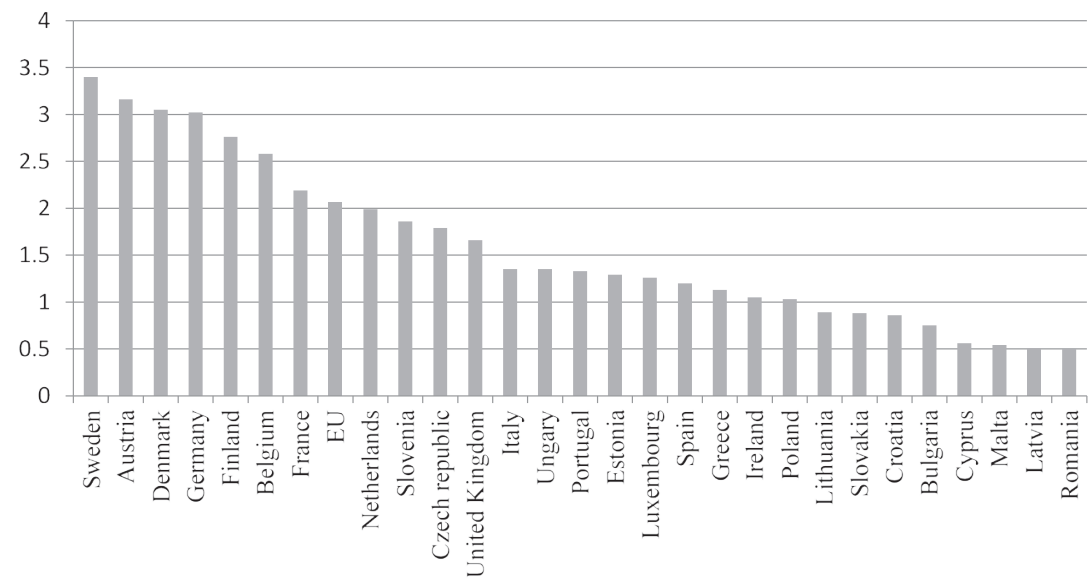

Figure 1. R\&D expenditure (\% n GDP) in EU Member States in 2018

Source: Author's conclusions are based on CSB databases

Latvia's total R\&D expenditure in 2018 was 186.2 million EUR (CSB database, 2020). Research organisations account for almost $50 \%$ of total investment, while entrepreneurs make up just under 25\% (46.3 million EUR). In other OECD countries, firms have resumed their R\&D investment since the financial crisis, fuelled by restored profitability and the increasingly generous R\&D fiscal incentives offered by many governments (OECD, 2018). Enterprises in Latvia, compared to those in other EU Member States, are characterised by their lack of innovation perspective, small size, low added value/complexity, high resource intensity and lack of integration into global value chains (Szydłowsk, 2019).

Expenditure in $R \& D$ in Latvia is small and dependent on European Structural Funds (currently R\&D investments are mainly attracted by EU funds), which is not a sustainable solution for $R \& D$ development, considering that this financing and its availability are periodic and in the future. This requires consistent long-term public and private (business) $R \& D$ investment. Without further substantial increases in $R \& D$ investment, it will not be possible to provide the economic knowledge needed for 
faster growth, human resources, technological development progress and business incentives to invest in R\&D and innovation. Government support is essential to promote basic research, and to provide incentives and appropriate conditions for effective science-industry relationships. In addition, it is crucial that public investment in $R \& D$ is channelled through public budgets and not just EU funds. Latvia is one of the largest recipients of EU funds in relation to its GDP and relies heavily on the EU budget to finance public investment and policies support to innovation and skills development (Szydłowsk, 2019).

In more detail, the main source of $R \& D$ funding in 2018 was European Commission funding (65.5 million EUR, or 35\% of total R\&D expenditure). Most of the EU funds are spent on $R \& D$ in universities and research institutions. The second most important source of funding in 2018 was the research base and development funding from the state budget (32.9 million EUR, or $18 \%$ of total R\&D expenditure). The third source of higher R\&D expenditure was self-financing by companies (30.9 million EUR, or $17 \%$ of total $R \& D$ expenditure)

An important insight into the development of the R\&D system is also provided by the analysis of the results between of different investment programs. It allows for an in-depth analysis of $R \& D$ performance within each RIS3 area, as well as identifying sector specificities and different needs for developing $R \& D$ capacity in each area (see Figure 2).

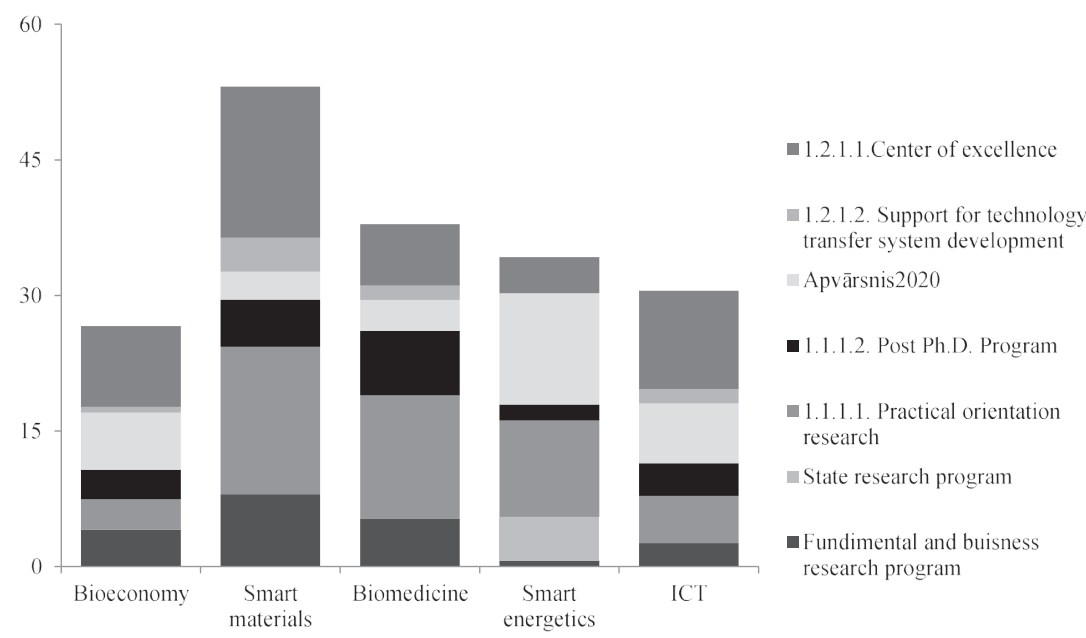

Figure 2. Financing R\&D broken down by source in Latvia 2014-2018 (million EUR) Source: Author's conclusions are based on EUROSTAT databases 
Overall, as shown in Figure 2, most financial resources are invested in smart materials. In turn, for the development of smart energetics spent on all national research programs as well as most of the Horizon 2020 funds.

\section{Conclusions, proposals, recommendations}

The 2014-2020 financial instruments, while generally contributing to the development of research and innovation capacity of scientific institutions and enterprises, have not provided a sufficiently integrated approach to linking research and technological development and, consequently, developing innovation capacity.

The current high dependence on structural funds may not be sustainable in the longer term, so Latvia should seek a better balance between national and European funding.

The new period should be shaped by defining more capacious and mutually integrated instruments, as well as more specific objectives and clear and measurable indicators of the results to be achieved. Identified thematic sub-areas in $R \& D$ projects should be taken into account in the planning and definition of strategic ecosystems.

In the design of programs, it is necessary to work on the reduction of the administrative burden where activities aimed at reducing the administrative burden on researchers and higher education projects cofinanced by EU funds are already underway.

There is also an identified need for better knowledge transfer, which would imply the need to develop targeted university-based knowledge transfer activities with a view to establishing functional platforms for transferring knowledge and technology to the public, including entrepreneurs (implementation of extension services).

\section{REFERENCES}

Central Statistical Bureau (CSB) of Latvia. (2020). Statistic Database. [Online] Available at: https://www.csb.gov.lv/lv/statistika/db [Accessed 20.102.2020].

Cross-Sectoral Coordination Centre. (2012). National Development Plan. Available: http:// www.pkc.gov.lv/sites/default/files/inline-files/NDP2020\%20English\%20Final 1. pdf. [Accessed 16.11.2019].

David Coe, Elhanan Helpman. (1995). International R\&D spillovers. European Economic Review. 39 (5), pp. 859-887.

Eiropas Komisija. Komisijas dienestu darba dokuments 2019. gada ziṇojums par Latviju. [Online] Available at: https://ec.europa.eu/info/sites/info/files/file_import/ 2019-european-semester-country-report-latvia_lv.pdf [Accessed 16.11.2019].

Eiropas Komisija. Pētniecība un inovācija [Online] Available at: https:/europa.eu/ european-union/sites/europaeu/files/research_lv.pdf [Accessed 16.11.2019]. 
European Commission. (2010). Europe 2020 strategy. Available at: https://ec.europa. eu/info/business-economy-euro/economic-and-fiscal-policy-coordination/eueconomic-governance-monitoring-prevention-correction/european-semester/ framework/europe-2020-strategy_en. [Accessed 16.11.2019].

Eurostat (2020). Statistic Database. [Online] Available at: http://ec.europa.eu/eurostat/ data/database [Accessed 20.102.2020].

Griffith, R., Redding, S. and Reenen, J. (2004). Mapping the Two Faces of R\&D: Productivity Growth in a Panel of OECD Industries. Review of Economics and Statistics. 86 (4), pp. 883-895.

Jesiḷevska, S., Šḳiltere, D. Inovācijas Latvijā. Realitāte un izaicinājumi. [Online] Available at: http://www.lza.lv/LZA_VestisA/72_4/5_Svetlana\%20Jesilevska_Daina_Skiltere. pdf [Accessed 16.11.2019].

Latvijas nacionālā reformu programma "Eiropa 2020" stratēğijas īstenošanai. Progresa ziṇojums 2019 [Online] Available at: https:/ec.europa.eu/info/sites/info/ files/2019-european-semester-national-reform-programme-latvia-lv.pdf [Accessed 16.11.2019].

OECD Science, Technology and Innovation Outlook 2018 (2018), OECD Publishing, Paris.

Priede, J., Pereira, E. (2013). Innovation as a key factor in the international competitiveness of the European Union, European Integration Studies. 2013 (No. 7), pp. 212-221.

Romer, Paul M. (1990). Endogenous Technological Change. Journal of Political Economy. 98 (2), pp. S71-S102.

Schumpeter, Joseph A. (1982). The Theory of Economic Development: An Inquiry into Profits, Capital, Credit, Interest, and the Business Cycle. $10^{\text {th }}$ ed. London: Transaction Publishers. p. 224.

Solow, Robert M. (1956). A Contribution to the Theory of Economic Growth. The Quarterly Journal of Economics. 70 (1), pp. 65-94.

Szydłowsk, K., Zeps, V., Reklaitis, Z. (2019). Proposal of revenue sharing operational model and its implementation into the innovation ecosystem of Latvia which could be implemented within the framework of 2021-2027 Planning period, September 1, 2019, Available at: https://em.gov.lv/files/attachments/Revenue\%20 sharing\%20operational\%20model\%20\%20Latvia_Deliverable\%20FINAL_2509_ Deliverable.pdf [Accessed 20.02.2020]. 


\title{
STRUCTURAL ANALYSIS OF INWARD FOREIGN DIRECT INVESTMENT IN LATVIA
}

\author{
Aleksejs Jurša ${ }^{1}$ \\ Mg. oec. \\ Faculty of Business, Management and Economics, University of Latvia
}

\begin{abstract}
The aim of this article is to investigate the activity of foreign direct investors in Latvia and find out what is the main source of financing for foreign investors new investments or reinvested earnings. In order to achieve the set goal and test the hypothesis, the methodology of Sixth Edition of the International Monetary Fund's Balance of Payments and International Investment Position Manual was used to define the types of foreign direct investment. This methodology was adapted to Latvian data. At the request of the author, Ltd Lursoft IT selected business data on all registered companies with foreign capital in Latvia since 2005 and aggregate data were used in the analysis. Foreign direct investment in Latvia flows mainly in the form of reinvested earnings, due to the profit earned from operating activities in Latvia. While new investments or greenfield investments in equity is lower compared to the amount of reinvested earnings. The results of the study reflect the business results of foreign direct investors in Latvia, as well as their actions in relation to the earned profit from operating activities. These results could be used by the Ministry of Economics of the Republic of Latvia and the Investment and Development Agency of Latvia to improve Latvia's investment environment and implement a more effective investment attraction strategy.
\end{abstract}

Keywords: Latvia; Foreign Direct Investment; Greenfield Investment; Brownfield Investment; Investment Climate

\section{Introduction}

In today's world of globalisation and high-tech technology, the growth of the country's economics is largely linked to the rapid introduction of modern, state-of-the-art production tools and technologies. Therefore, many countries nowadays, especially those undergoing economic transition, face a dire need to activate investment operations to increase competitiveness, modernise existing production structures and create new products, which is especially important in today's saturated market and rapidly changing conditions. Foreign direct investment (FDI) is a type of

1 Contact: Aleksejs Jurša; aleksej.jursa@gmail.com; Faculty of Business, Management and Economics, University of Latvia, Riga, LV-1050, Latvia. 
foreign investment aimed at establishing a new, independent company or expand an existing business through merger or takeover. Today, these investments have become one of the most important aspects of the development of international companies. FDI has also been linked to a number of economically beneficial developments. They are a source of new technologies and innovations, as well as a source of new jobs and an improvements in infrastructure. Thus, FDI is an important financial instrument with a significant role in the development of economics, especially in countries where the local capital is limited. Such investments are subject to a variety of difficulties and opportunities and, therefore, FDI-related research will continue to be relevant and important in the future.

Keeping in mind the unsuccessful approach leading up to 2008 (or before Latvia's economy was hit by recession), prudent bank crediting policy prevents companies from obtaining the necessary flow of money for investments. The existing approach of the banks in issuing loans is much more careful. On the other hand, other types of financial instruments are limited; risk capital is very poorly developed in the Latvian market, but the issuance of bonds is relatively expensive. Prudent commercial banking policy is not the only reason for weak local investment activity. Based on a study by Stockholm School of Economics in Riga on the shadow economy in the Baltic States, in Latvia, the shadow economy in 2019 was $23.9 \%$ of GDP which is a high number. The largest share of the shadow economy in Latvia is accounted for by envelope wages and non-declared income, respectively $44.1 \%$ and $32.0 \%$ of the total shadow economy in Latvia (Stockholm School of Economics, 2020). It is also important to note that out of all companies that submitted annual reports to Lursoft IT Ltd in 2019 (109.5 thousand companies) only 66 thousand had an annual turnover up to 12 million euro. In turn, only $56.8 \%$ of these companies have positive equity and positive profits. Consequently, it can be concluded that the range of potential companies to which commercial banks can issue loans to is limited. Thus, it must be concluded that the faster investment development is hindered by both demand and supply factors. In the light of low investment activity, it is very difficult to increase productivity and reduce unemployment on a national scale. Until then, foreign direct investment can supplement local capital, thus solving existing problems and "building" a competitive economy in the long run.

The aim of this article is to evaluate the activity of foreign direct investors in Latvia, describing the economic indicators of companies for the last 15 years. Since the restoration of Latvia's independence, Latvia has attracted almost 16 billion euro of foreign direct investment. This corresponds to $52.3 \%$ of Latvia 's nominal GDP in 2019. There have been no studies on whether this significant inflow of financial resources was invested in the creation of new companies or the so-called "greenfield" investments 
were made or in the takeover of existing companies. Therefore, the main hypothesis of the research is to find out whether the current investment environment in Latvia is favourable for acquisitions of local companies by foreign investors, but not for setting up new businesses. The results showed that foreign direct investment in Latvia flows mainly in the form of reinvested earnings, due to the profit earned from operating activities in Latvia. New or greenfield investments in equity form are lower part of the total incoming FDI, which indicates that there is bottleneck in attractin new FDI. The annual reports of FDI enterprises were used for data processing.

\section{Literature review}

The initial studies in the field of FDI were conducted in the $19^{\text {th }}$ century, but these combined general notions incorporating the spheres of policy, economics and history. Overall, there are two approaches to studying investment roots, that is, approaches by F. Hayek and J. M. Keynes. The approach by F. Hayek (1941) relies on the fact that investments are viewed as moving to a state of equilibrium, because the optimum amount of investments depends on how fast something should be done (Hayek, 1941). Whereas capitalists are more interested in what would be the optimal amount of investment for a specific period of time. According to the theory by J. M. Keynes, the concept of optimal investment is linked not to "optimal adaptation" but to "optimal behaviour". In essence, Keynes's theory omits the issue of discussion about fluctuating accumulated capital, until much later it was brought to light by growth theorists (Keynes, 1936). Modern Neo-Keynesian and Post-Keynesian scholars sought to incorporate accumulated capital into Keynes' theory in order to obtain a "more complete" theory of macroeconomics.

Over the past 70 years, many researchers have tried to explain the phenomenon of FDI, while failing to crystallise a single, generally accepted theory of FDI. The Product life-cycle theory developed by R. Vernon was based on US investment. In general, this theory explains commodity exports and incoming FDI in Western Europe from the US between 1950 and 1970 (Vernon, 1966). This theory shows the change in the amount and geography of FDI depending on the product life cycle, from the invention of the product, to the export, to the establishment of manufacturing companies in the target country.

The theory of internationalisation is based on an explanation of the development of transnational companies and their motivation to perform FDI (Coase, 1937). Internalization theory goes beyond concentrating on transaction cost economizing to recognize a variety of strategic and managerial issues involved in internationalization, and to focus on managing the innovation process in its entirety (Buckley and Casson, 1976). The theory 
of internationalisation, suggests how the joint management of different production processes in different places can increase the demand for goods (Buckley and Casson, 2009). Transnational corporations with subsidiaries in several parts of the world but weak co-operation are less competitive than transnational corporations, which are able to integrate each subsidiary with a certain function in the overall production chain (Casson, 2000).

Taking into account the reality and complexity of multinational enterprises, especially from emerging economies, including both their successes and, in some cases, their lacklustre economic performance, a new internationalisation theory has developed over the last twenty years. The emphasis shifted from explaining the parameters that would stimulate firms to expand across borders, and investigating entry mode choice, to the multinational enterprises internal organization and their network capabilities (Verbeke and Kano, 2015). Globalization has modified the 'ecosystem' in which firms exist: globalization allows accelerated internationalization and new opportunities for domestic firms to become multinational enterprises (Narula, 2012). New theory focuses on managing interdependencies between economic actors located in different countries, and draws attention to the role of complementary resources of foreign actors that the multinational enterprises may require in order to enable the exploitation of its own firm-specific advantages (Hennart, 2009). In contrast to conventional, mainstream internalisation theory, the new internalisation theory focuses on the dynamics of international governance, whereby value creation hinges on successful knowledge recombination and governance choices are assumed to change over time (Verbeke and Kano, 2012). The theory of internationalisation was also widely commented on by J. Danning. Later, this theory became the basis for his eclectic paradigm.

The eclectic paradigm provides an explanation on how to rationally use resources and organise operations. It combines and integrates ownershipspecific $(\mathrm{O})$, location specific (L) and internalisation (I) factors in articulating the benefits of international production. The paradigm is intertwined with the theory of international trade $(\mathrm{L})$ from the macroeconomic point of view and theories of enterprise development from a microeconomic point of view (O and I) (Dunning, 1988). All three variables are important in determining the size and strategy of FDI. In general, the eclectic paradigm provides a broader view compared to other theories, explaining the necessity of FDI. The theory explains the causes of a firm's international expansion, arguing that the geographic extent ant the industrial element of foreign productions of multinational enterprises are determined by the interaction between three interdependent variables (Dunning, 2001). Over the last 30 years since the introduction of this theory the business environment has changed significantly, however the OLI model is still largely relevant. The eclectic paradigm has been extensively used to explain the growth 
of multinational enterprises in various industries and types of activity. However, the three variables (OLI) have been contested on the context of economic globalisation (Ribau et al., 2015). The eclectic paradigm, like other theories of FDI, has some limitations, however. First, the paradigm does not explicitly delineate the ongoing, evolving process of international production. FDI itself is a dynamic process in which resource commitment and production scale are changing over time. Second, the conventional wisdom seems inadequate in illuminating how geographically dispersed international production should be appropriately coordinated and integrated (Shenkar, 2007). To a large extent, the above range of questions can be extended to other theories too.

It can be concluded that there is no single theoretical explanation of the nature, flow volume and motivation of FDI. Each theory offers its own motivating and influencing FDI factors. Each investment project is individual, so none of the theories explain all the possible influencing factors, but gives an idea of general theoretical explanations.

An important issue in analysing FDI is the investment climate. Most of the explanations lead to the common conclusion that the investment climate is political, legal and institutional environment affecting the functioning of the market and risks associated with starting, operating, and closing a business (World Bank Group, 2015). The issue of the investment environment is focused on institutions and policies that affect the productivity of accumulated investments and the willingness to invest over a long period of time. Assessing the investment environment at the global level is a strategic issue, assessing the benefits and potential risks of specific investments in a particular country (Kahraman, 2011). Looking more closely at the investment environment, the author concludes that the factors that attract FDI largely have a common objective - to reduce costs through the economic advantages of another country, thus increasing profits. A larger market for product consumption contributes to cost reduction and improve resource efficiency. Therefore, a large market creates the opportunity to increase profit. Low labour costs are not always commensurate with high productivity and science-intensive technologies, but they have a significant impact on attracting FDI. Another important factor is exchange rate fluctuations and the stability of the tax policy of the recipient country, which directly affects the investor's profit.

There are different classifications of foreign investments in modern academic literature. Foreign investment can be divided into two large groups, namely portfolio investment and direct investment. Portfolio investment is the acquisition of a foreign company securities with the aim of increasing the value of the initial capital, as well as receiving dividends. While, the main purpose of foreign direct investment is to acquire a qualifying holding in a foreign company in order to participate 
in the management of the company and in the process of making strategic decisions (Pike and Neale, 2006).

Based on IMF's Balance of Payments and International Investment Position Manual, foreign direct investment is a category of cross-border investment associated with a resident in one economy having control or a significant degree of influence on the management of an enterprise that is resident in another economy. Direct investment implies a long-term relationship between a direct investor and direct investment enterprise. Immediate direct investment relationships arises when a direct investor directly owns equity that entitles it to 10 percent or more of the voting power in the direct investment enterprise (International Monetary Fund, 2009). The components of direct investment are equity and debt instruments.

Equity is a financial asset that is a claim on the residual value of a corporation, after the claims of all creditors have been met. It incorporates listed shares and other equity. The acquisition of the historic investment and new investments in a direct investment enterprise are included. Reinvested earnings are a part of the enterprise's profit or loss that belongs to the direct investor in proportion to its holding and remains at the disposal of the direct investment enterprise and are reported under direct investment separately from equity. While debt instruments are trade, borrowing and lending transactions conducted between direct investors and direct investment enterprises (Bank of Latvia, 2020).

Depending on the amount of foreign direct investment in a given company, the foreign investor's motivation and purpose may be different. FDI can be made to start a completely new business abroad, commonly referred to as a greenfield investment, as well as in the full or partial acquisition of an existing business or in the form of a merger or takeover. FDI can be in three forms.

The first form is greenfield investment. Greenfield investments imply the creation of new subsidiaries in the host economies. Due to the reason that greenfield investments are made in new assets, it has a more favourable impact on economic growth than the other two types of FDI capital inflows. For the same reason, much more time is needed for greenfield investments projects implementation. This type of FDI investment is mostly targeted to less competitive markets and more frequently in developing economies. One of the difficulties in the measurement of greenfield investments is the time element, i.e. for how long a direct investment should be considered as greenfield investment. There are assumptions that an investment will cease to be classified as greenfield 4 to 5 years after the initial investment. However, there are no agreed standards on this and other related items (Bertrand, 2004).

The second form is extension of capacity. This type of FDI does not create a new economic activity, but develop already an existing one. It 
is an investment in previously established direct investment enterprises in the form of an increase in share capital or reinvested earnings. The extension of capacity of direct investment enterprises are at times confused with greenfield investments, while in both cases the underlying concept relates to the creation of new or additional capital stocks (Bertrand, 2004).

The third form is mergers and acquisitions. Mergers arise when two or more companies agree to combine into a single operation. While acquisitions involve the purchase of one company by another company. Mergers and acquisitions data are not identified as standard components within FDI. Nonetheless, there may be interest in such data because the nature of mergers and acquisitions may differ from other FDI, for example, they may not provide any new financing for the firms involved, but rather represent a change in investors (International Monetary Fund, 2009). The extension of capacity and mergers and acquisitions FDI is classified as brown field investments.

\section{Research methodology}

Given that there are no statistics on the establishment of new companies with foreign capital in Latvia (greenfield investments), as well as separate investments of capital increase and mergers and acquisitions (brownfield investment), there is a lack of data to answer the question, whether the current investment environment in Latvia is more favourable for foreign investors to buy local companies or establish new ones.

Based on the current $6^{\text {th }}$ edition of the IMF's Balance of Payments and International Investment Position Manual FDI definition (International Monetary Fund, 2009) and the theory discussed above, the author defined greenfield and brownfield investments as follows. The amount of share capital of a new company was considered to be a greenfield investment. First, when a foreign resident establishes a completely new company in Latvia and all $100 \%$ of the company's shares are owned by a foreign investor. In this case, the amount of share capital is greenfield investment. Secondly, when a foreign resident establishes a completely new company in Latvia together with a Latvian resident, but on the condition that the foreign investor owns at least $10 \%$ of the company's shares. In the second case, only the part of the share capital that belongs to the foreign resident is considered as FDI. While, brownfield investments were considered to be capital increase investments. Capital increase investments can be identified when a foreign resident, natural or legal person, invests in a company registered and operating in Latvia, provided that at least $10 \%$ of the shares of a company registered in Latvia that were previously owned by a Latvian resident were acquired. To 
paraphrase the above, the company's shares are sold and the ownership of the shares is changed. It is important to note that in this case no new economic activity is created. In the theory section, another type of incoming FDI was noted - merger and acquisition investments. Regarding this type of investment, due to the limited data, it is difficult to determine the situation when a company with foreign capital merges with a Latvian capital company and forms a new company. Thus, merger and acquisition investments are not analysed in this study. Based on this methodology, Lursoft IT Ltd specially selected the necessary data at the request of the author. Further analysis is based on data prepared by Lursoft IT Ltd. for period from 2005-2019 and Bank of Latvia data on foreign direct investment.

\section{Research results}

Foreign direct investment plays a significant role in the growth of Latvia's economy, but there is a noticeable degree of cyclicality in the intensity of the flows. The inflow of FDI in Latvia rapidly intensified after accession to the EU (see Figure 1). This was a positive signal for foreign investors, as by convincingly meeting all the Maastricht criteria, the Latvian state confirmed its readiness to integrate into a unified European economic system. It also confirmed its economic balanced development, as Latvia's performance in meeting the Maastricht criteria was well below the critical value.

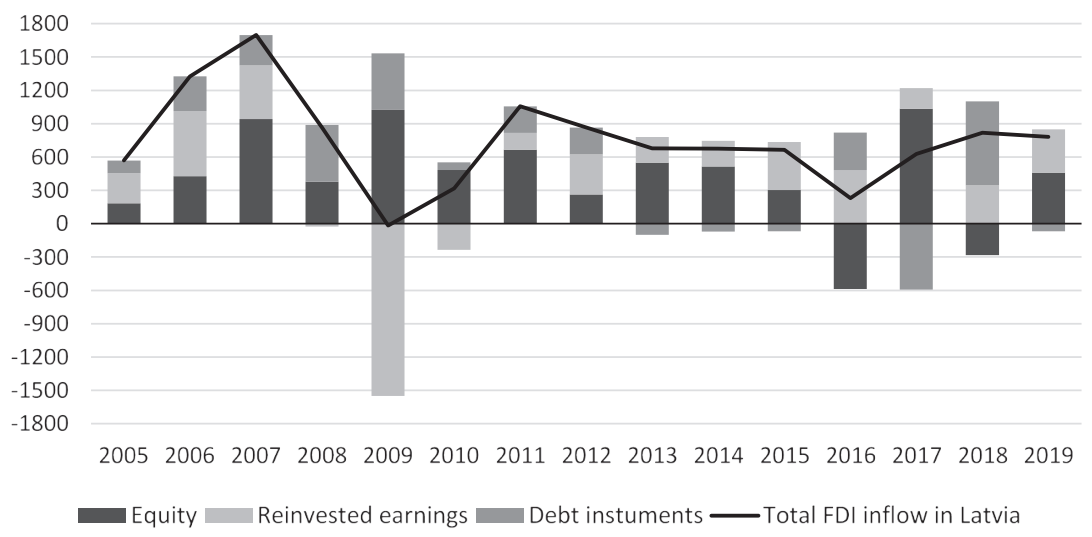

Figure 1. Net flows of foreign direct investment in Latvia, milion euro Source: author's compilation based on Bank of Latvia data

Since the restoration of Latvia's independence, Latvia has attracted 15,925 million euros of foreign direct investment. This corresponds to $52.3 \%$ of Latvia 's nominal GDP in 2019. Almost $80 \%$ of the accumulated 
FDIs were invested in the share capital of companies and reinvested in the development of the company, in other words, they were no-debt flows. This means that most of the incoming FDIs in Latvia were invested in the company's stock, capital shares, intellectual and real estate, thus promoting the growth of the Latvian economy and infrastructure development.

The amount of accumulated FDI in the form of debt instruments in 2019 was $20 \%$. Investments in debt instruments are reflected in the relationship between the direct investors and direct investment enterprises, which is affected by mutual acquisitions and disposals of debt securities issued by direct investors and direct investment enterprises. As soon as a "parent" or foreign investor company issues a loan to a "subsidiary", incoming and accumulated FDI increases. However, by repaying the loan to the "parent" company, the amount of FDI decreases. From an economic point of view, this is to be welcomed, as in this case the company is likely to expand or modernise its operations. However, loans need to be repaid and loan repayments mean an outflow of foreign direct investment. Accumulated FDI in the form of debt instruments has increased significantly from 584 million in 2000 to 3,239 million euro in 2019. However, the share of debt instruments in total accumulated FDI has gradually declined.

Until 2008 (years of rapid economic growth), the dominant flows were equity and reinvested earnings; other capital, which is loans among direct investors, were not the most significant. With the onset of the global economic and financial crisis, the flow of FDI decreased significantly, including in Latvia. Between 2008 and 2010, a large number of foreign-owned companies suffered losses. At the peak of the Latvian economic downturn in 2009, FDI losses amounted to 1,549 million euros. Thus, the inflow of FDI in that year was negative and amounted to -16 million euros.

After the economic crisis, FDI inflows were positive but modest. For example, the average inflow of FDI during the period from 2010 to 2013 was 729 million euros while the average flow before the economic crisis from 2005 to 2008 was 1,114 million euro. The situation was later exacerbated by the escalation of the military conflict between Russia and Ukraine. Increased political tensions in the region is one of the main negative factor that worsened the investment climate in all Baltic countries in 2014. In recent years, the inflow of FDI has fluctuated from 230 million euros in 2016 to 819 million euros in 2018. In 2019, the amount of FDI was 781 million which is broadly in line with the average investment dynamics over the last decade. In 2019, the total inflow of FDI was divided between equity investments (460 million euros), reinvested earnings (388 million euros), while the amount of debt instruments was negative (-67 million euros). 
Repatriation of profits to the investor's country of residence is considered in the scientific literature as a negative factor of FDI, therefore it is important to assess the amount of profits that remained in Latvia and were invested in the company's development and the share of dividends paid to foreign investors. Reinvested earnings are those parts of the enterprise's profits or losses which, according to the shareholding, belong to the direct investor. Thus, even if no new foreign direct investment enters Latvia, the amount of FDI may still change at the time of profit distribution. The company's operating profit increases FDI, but decreases it in the event of a loss or dividend payment. Figure 2 shows that the amount of dividends paid to direct investors has been stable even during the economic crisis period: 2009-2010.

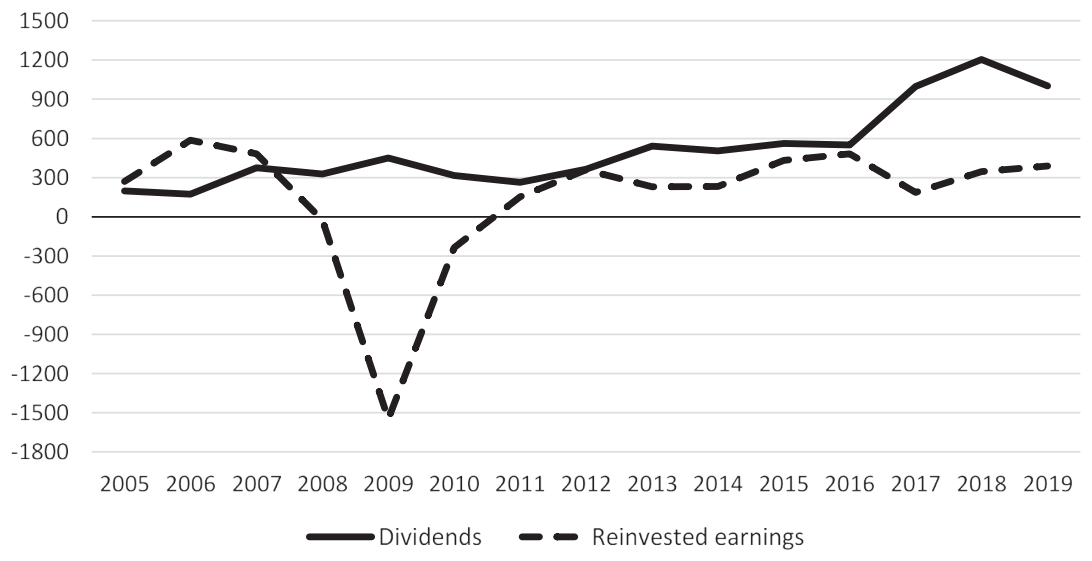

Figure 2. Amount of reinvested earnings of foreign direct investors and amount of dividends paid to foreign direct investors, million euro

Source: author's compilation based on Bank of Latvia data

Foreign direct investors received 1,074 million euros in dividends from 2005 to 2008, while the amount of incoming FDI in this period was 4,455 million euros. This means that for every euro invested, an average of 25 cents was paid out to direct investors in the form of dividends. However, from 2011 to 2014, this proportion changed significantly. During this period, 3,275 million euros of FDI flowed into Latvia, while the amount of dividends paid to direct investors amounted to 1,671 million euros, which means that approximately 51 cents of each foreign euro were returned to investors. In the period from 2015 to 2019, this proportion continued to increase in favour of dividend payments, and out of each euro invested, an average of 1.38 euro was paid to foreign investors in dividends. 
The growing amount of dividend payments is related to the amount of accumulated FDI. The amount of accumulated FDI in 2004 was 3.3 billion euros, in 2008 it was 8.1 billion euros, in 2014 it was 12.1 billion euros, and in 2019 - 15.9 billion euros. Undoubtedly, the invested capital cannot bring a profit immediately, but a higher accumulated capital also increases the actual profit, thus the amount of dividends also increases.

The payment of the large amount of dividends in recent years was also stimulated by the tax reform, which entered into force on 1 January 2018. The number of dividends paid to foreign direct investors in 2018 reached an all-time high (1,204 million euros). This amount of dividends is more than twice as high as in 2016, when the amount was 550 million euros. It should be noted that a significant increase in the amount of dividends paid was recorded before the tax reform in 2017, when 997 million euros were paid in dividends to direct investors. Such a rapid increase in the amount of dividends paid can be explained by the fact that discussions on tax reform were started already in 2016, but at the beginning of 2017 the main directions of tax reform were known. Tax reform aimed to increase interest rates on dividends paid from $15 \%$ to $20 \%$. It can be assumed that companies wanted to minimise their expenses by paying $15 \%$ tax on profits instead of the $20 \%$ rate that would be after 2018. The amount of dividends paid in 2019 decreased compared to the previous year, but was still at a high level and amounted to 1,001 million euros. In general, it should be noted that a year before and two years after the introduction of the tax reform, the amount of dividends paid to direct investors has increased significantly. In the period from 2018 to 2019, the average amount of dividends paid to foreign investors was 1,103 million euros per year, while the average amount of dividends in the five years prior to the introduction of the tax reform was 631 million euros per year.

The significantly higher amount of dividends paid since 2017 was also determined by the significantly higher amount of foreign-related corporate profits in this period. With the gradual improvement of the economic situation, the profits of foreign investors have been steadily increasing, from EUR 80 million in 2010 to EUR 1549 million in 2018 and EUR 1389 million in 2019. The change in the procedure for payment of corporate income tax had a positive effect on the amount of profit of foreign investor companies, but the record-high profit in 2018-2019 was largely determined by the favourable economic development in general.

The increase in the share of dividends in profit distribution also indicates that the amount of dividends paid has increased since 2017. In $2017,84 \%$ of the profit was paid in dividends and $16 \%$ was reinvested in the development of the company. In 2018, this proportion was $78 \%$ against $22 \%$, but in 2019 it was $72 \%$ and $28 \%$. In the period from 2012 to 2016 , or on average over five years, this proportion was $60 \%$ and $40 \%$, respectively. 
However, it should be taken into account that dividends can also be paid for the previous period, thus in this case it is not possible to precisely determine the direct impact of the change in the CIT payment procedure on the dividend payment.

In 2019, 21,228 companies with foreign capital were registered in Latvia. However, only $59 \%$ (or 12,435 of the total number) were engaged in economic activity. Most of the companies registered in Latvia with foreign capital, are fully owned by foreign residents. At the end of 2019, 74.5\% of economically active enterprises in Latvia with foreign capital were fully subsidised by foreign investors. $16.9 \%$ of cases, foreign investors held $50 \%$ or more of the company's capital shares, but less than $100 \%$. In only $8.6 \%$ of cases, these were Latvian and foreign joint ventures, where the share of foreign investor shares ranged from 10 to $50 \%$. Detailed statistics on the share of foreign direct investors' share capital and the aggregated business indicators of these enterprises (breakdown by years) are presented in Table 1 .

Table 1. FDI enterprises data in Latvia. Distribution of foreign direct investors in Latvia by share of equity and aggregated business indicators of these enterprises in 2005 and 2019

\begin{tabular}{|c|c|c|c|c|}
\hline \multirow{2}{*}{$\begin{array}{c}\text { Aggregated business indicators } \\
\text { of FDI enterprises }\end{array}$} & \multicolumn{4}{|c|}{ Distribution of foreign direct investors by share of equity } \\
\hline & $=<10 \%>50 \%$ & $=<50 \%>70 \%$ & $=<70 \%>100 \%$ & $100 \%$ \\
\hline \multicolumn{5}{|l|}{2005} \\
\hline Number of enterprises & 1678 & 1861 & 1087 & 8264 \\
\hline $\begin{array}{l}\text { Number of economically } \\
\text { active enterprises }\end{array}$ & 1201 & 1262 & 731 & 5210 \\
\hline $\begin{array}{l}\text { Number of economically } \\
\text { active enterprises with FDI } \\
\text { out of the total number of } \\
\text { enterprises with FDI, \% }\end{array}$ & $14.3 \%$ & $15.0 \%$ & $8.7 \%$ & $62.0 \%$ \\
\hline Turnover, EUR million & 2847 & 1375 & 2110 & 11187 \\
\hline Profit, EUR million & 375 & 109 & 93 & 291 \\
\hline \multicolumn{5}{|l|}{2019} \\
\hline Number of enterprises & 1381 & 1839 & 984 & 17024 \\
\hline $\begin{array}{l}\text { Number of economically } \\
\text { active enterprises }\end{array}$ & 1071 & 1375 & 726 & 9263 \\
\hline $\begin{array}{l}\text { Number of economically } \\
\text { active enterprises with FDI } \\
\text { out of the total number of } \\
\text { enterprises with FDI, \% }\end{array}$ & $8.6 \%$ & $11.1 \%$ & $5.8 \%$ & $74.5 \%$ \\
\hline Turnover, EUR million & 1351 & 1610 & 1850 & 21730 \\
\hline Profit, EUR million & 95 & 123 & 111 & 1029 \\
\hline
\end{tabular}

Source: author's calculations based on SIA "LURSOFT IT" data 
In the last fifteen years the dominance of foreign investors in companies registered in Latvia with foreign capital increased because in 2005, for example, the share of companies fully owned by foreign residents was $62.0 \%$. Thus, it can be concluded that foreign residents are increasingly choosing a corporate governance model where they have full control over the company. On the other hand, the management of companies together with a Latvian resident is not considered to be an attractive company management model.

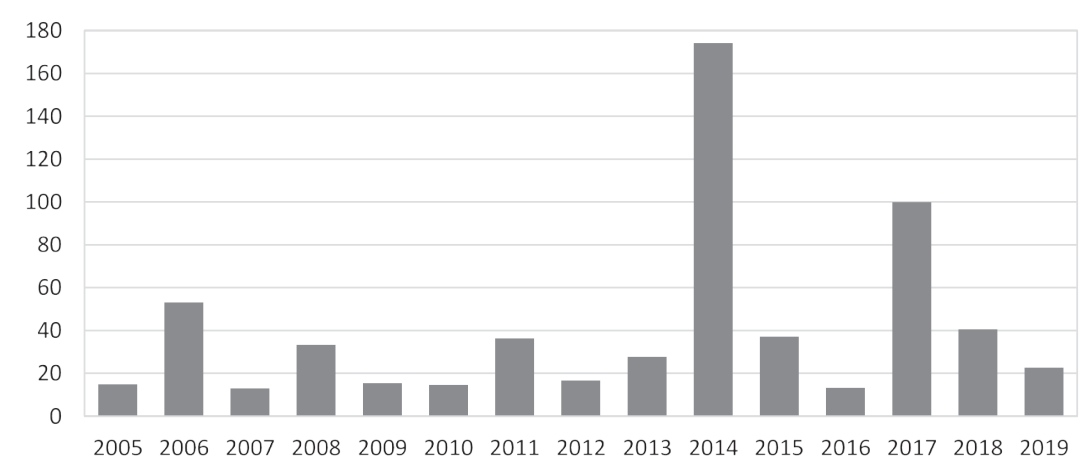

Figure 3. Inflow of greenfield investments in Latvia, million euro

Source: author's calculations based on SIA "LURSOFT IT" data

Regarding greenfield investments, Figure 3 shows the amount of foreign direct investors' investments in newly established companies in Latvia by years. In 2019, the amount of investments of foreign direct investors in companies established in 2019 was only 22.7 million euro. The volume of this type of investment was also weak in the previous years, thus it can be concluded that the amount of investments in foreign capital of a company established by a foreign investor in Latvia is insignificant compared to the amount of reinvested earnings. If the time factor is applied to greenfield investments and it is assumed that the amount of reinvested earnings within four or five years from the establishment of the company is also greenfield investments (if the company has made a profit during this period), then the total amount of greenfield investments is clearly higher. In the theoretical section, it was already been noted that one of the difficulties in analysing greenfield investments is the time factor, namely how long foreign direct investment should be considered as greenfield investments. It is assumed that these may be four or five years after the establishment of the company, but there is no common methodology of this aspect. Given that there is no common understanding among scientists about 
the time factor, the author classifies incoming greenfield investments as an investment in the share capital in the year of formation of the company. The small amount of greenfield investments in the reflected period is due to the fact that most of the largest foreign investors have been operating in Latvia for a long time, therefore the amount of greenfield investments of individual companies must be sought in the year of establishment of the company which might be in the 1990s.

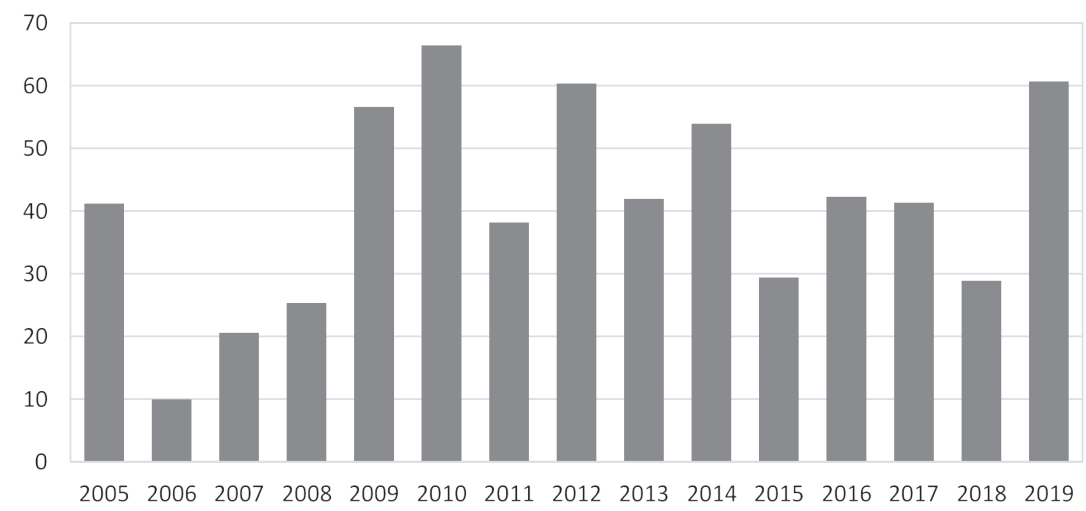

Figure. 4. Extension of capacity investments inflow in Latvia, million euro Source: author's calculations based on SIA "LURSOFT IT" data

Brownfield investments were considered to be capital increase investments. As can be seen in Figure 4, the amount of foreign direct investment with the aim of acquiring at least $10 \%$ or more from a company owned by a Latvian resident is quite volatile. In this way, investments became especially popular among foreign investors from 2009. Most likely, this is due to the fact that Latvian companies in difficulty during the crisis opted to choose to sell part or all of their shares to foreign residents, seeing no other opportunity for the company's development. On the one hand, this is to be seen in a negative light, as this type of FDI does not create new economic activity. If a foreign investor has acquired a controlling interest in the company, that is, $50 \%$ plus 1 share in the capital and more, further decisions on the development of the company, including the distribution of profits, will be made abroad. On the other hand, this type of investment also has a positive effect. First, the company and jobs are preserved. Secondly, a resident of Latvia retains capital which he/she can invest in setting up a new business. However, there is no doubt that incoming foreign direct investment, which is invested in existing companies, is less productive and less beneficial to economic development than greenfield 
investment. It should be noted that attributing the share of incoming FDI that went to the repurchase of domestic companies against FDIs in share capital, it can be concluded that this type of investment relative to total FDI in share capital has increased over the last fifteen years.

The financial crisis of 2008-2010 had a negative impact on economic activity in Latvia, thus the indicators of corporate earnings significantly deteriorated. Figure 5 shows that in 2008, companies that were wholly or partly owned by foreign direct investors suffered increased losses, reaching 600 million euros. That is more than the previous four years combined. In 2000 , the amount of losses was even higher and amounted to 672 million euros. From 2010 to 2014, the amount of losses gradually decreased. However, the number of companies that had losses in the reporting year has increased on the contrary (from 4874 companies in 2009 to 5224 companies in 2014). In 2017, the amount of losses in the reporting year reached 695 million euros, but the number of companies operating at a loss increased to 8287. Such results for 2017 and 2018-2019 (as the amount of losses was also significant in those years) can be explained as follows. Assessing the above results, the amount of profit of foreign direct investors (in recent years, foreign investors generally had a record amount of profit), it can be concluded that competition for market shares between foreign companies and local companies, as well as in the attraction of new consumers in Latvia is very high. Thus, there is a relatively large number of companies with foreign capital that operate at a loss in Latvia, do not withstand competition and are unable to successfully exist in the market.

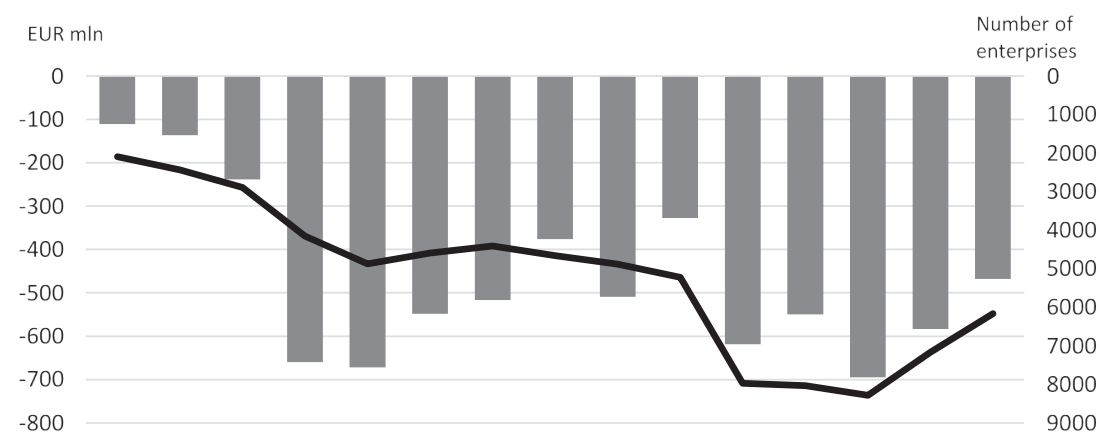

200520062007200820092010201120122013201420152016201720182019 The amount of loss, million euro Number of enterprises (right-hand scale)

Figure 5. Number of FDI enterprises operating at a loss and the amount of their losses in million euro

Source: author's calculations based on SIA "LURSOFT IT" data 
If a company with foreign capital is liquidated or the shares of a foreign resident are repurchased by Latvian residents, it means an outflow of foreign direct investment from the country. Figure 6 shows the number of companies and the amount of company shares in millions of euros that were sold to Latvian residents or liquidated. If in the early 2000s the outflow of FDI from Latvian-registered companies was small and related to legal factors, namely the protection of investors' rights and the fulfilment of contractual obligations, then in 2008-2010 the determining factor was the overall economic downslide. Starting from 2014, the investment environment both in Latvia and the other Baltic States was negatively affected by the deterioration of the geopolitical situation in the Eastern European region. Russia's illegal annexation of Crimea, EU-US sanctions against Russia and Russia's embargo on food imports from the EU and the US have destabilised the political and economic situation in the region.

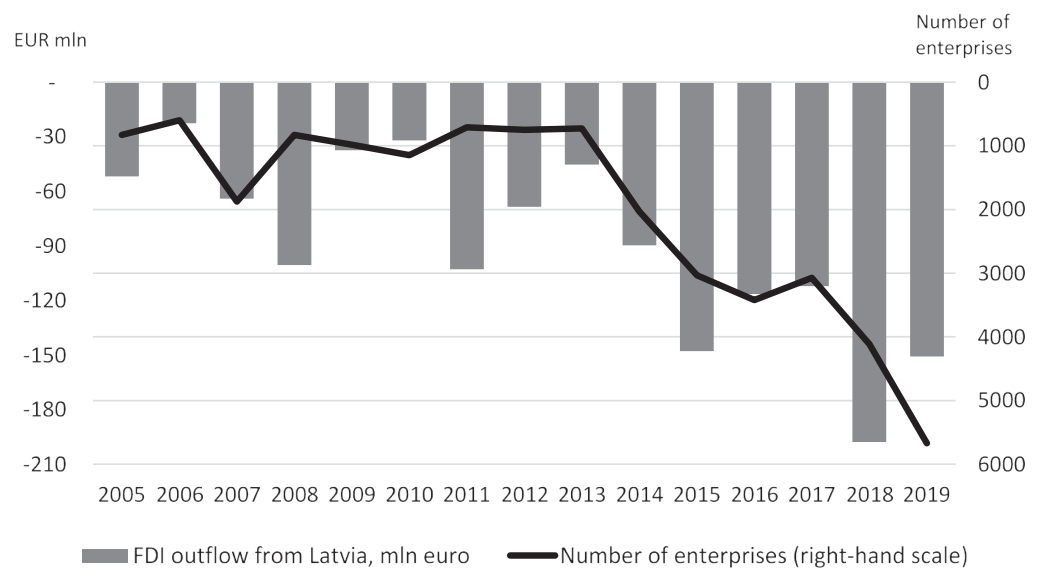

Figure 6. Outflows of FDI from Latvia in million euro and the number of FDI companies that reduced their share of equity

Source: author's calculations based on SIA "LURSOFT IT" data

In recent years, the largest outflow of FDI from Latvia has been recorded. Thus, in 2018, the amount of outflowing FDI from Latvia amounted to 198 million euros, but in 2019 - 151 million euros. The decision to reduce the share capital or liquidate the company in 2019 was made by a record number of foreign direct investors - 5,669 companies. The author has already pointed out that in recent years, despite the fact that foreign direct investors in Latvia generally worked at a profit, both the amount of losses and the number of companies operating at a loss increased at the same 
time. Consequently, the growing outflow of foreign direct investment from Latvia in recent years can be explained by a deterioration in profitability. Strong competition, rising labour costs that outpace productivity growth, a shortage of skilled labour and an aging population that narrows potential consumption in the medium and long term are the main reasons why foreign investors decide to leave the Latvian market.

In general, it can be concluded that volume of greenfield and brownfield investment is rather steady. However, the level of FDI in new projects is lower compared to the amount of reinvested earnings, due to the profit earned from operating activities in Latvia. The hypothesis of research is rejected. Investment environment in Latvia is favourable for FDI.

\section{Conclusions}

Foreign investors are diverse, and each has its own specific interests. Financial and strategic investors will be interested in completely or partially repurchasing an existing company or bank in order to increase the profit. Risk capital companies and investors invest in information and communications sectors and technological start-ups. Other foreign investors want to buy an existing company that already has a production process and supply chains in place to sell its products on the domestic market or export to other countries. Thus, in order to increase the amount of "green-field" investments and encourage foreign investors to reinvest more in the development of companies from the profits earned in Latvia, it is necessary to solve several structural problems.

Increasingly, it is not just countries that compete with each other to attract investment, but cities too; for example, when it comes to setting up some shared service centres or business process outsourcing centres. In this area, Riga often has to compete with Prague and other cities in Eastern Europe. The author notes that the range of available support mechanisms offered to entrepreneurs, including foreign investors, is wide, but the main ones are tax incentives. For example, special economic zones also exist in other European countries with favourable tax regimes. To attract more FDI, tax support mechanisms alone are not enough. As $55.0 \%$ of Latvia's economically active population lives in Riga and Riga Region, it cannot be expected that, with the exception of the Riga region, other regions of Latvia will succeed in attracting FDI, especially to high-tech sectors.

In order to improve the investment environment in the Republic of Latvia and increase the inflow of "green-field" investments, it is necessary to reduce several obstacles. First, the size of the shadow economy needs to be reduced, as this will not only make economic and business processes more transparent, but will also increase tax revenues, thus increasing 
the economic flexibility needed to implement structural reforms. Secondly, structural unemployment needs to be reduced through targeted labour market and education system reforms and measures to promote innovation. Third, comprehensive reforms in the education and court system, speeding up court proceedings and legal improvements in the field of insolvency need to be pursued. Energy policy is also one of the topical issues on the agenda of entrepreneurs, as the disproportionately high payment burden of the mandatory procurement component on manufacturing companies does not promote the inflow of new foreign investment into Latvia's manufacturing industry, where FDIs are very important.

\section{REFERENCES}

Annual bulletin Latvia's Balance of Payments. Bank of Latvia. (2020). Retrieved 25 October 2020, from: https://datnes.latvijasbanka.lv/lmb/LMB_2019.pdf.

Balance of Payments and International Investment Position Manual. International Monetary Fund. (2009). Retrieved 10 November 2020, from: https:/www.imf.org/external/ pubs/ft/bop/2007/pdf/bpm6.pdf.

Bank of Latvia, (2020). Balance of Payments (BOP), International Investment Position (IIP) and International Trade in Services (ITS). Available at: https://statdb.bank.lv/lb/ Data/200 [Accessed 20.11.2020.].

Bertrand, A. (2004). Mergers and acquisitions, greenfield and extension of capacity. Direct Investment Technical Group. Retrieved 10 October 2020, from: https://www. imf.org/external/np/sta/bop/pdf/diteg42829.pdf.

Buckley, P. J., Casson, M. (2009). Internalisation Theory of the Multinational Enterprise: A Review of the Progress of a Research Agenda after 30 year, Journal of International Business Studies, 40(9), 1563-1580.

Buckley, P. J., Casson, M. (1976). The Future of the Multinational Enterprise, Palgrave Macmilian UK.

Casson, M. (2000). Enterprise and leadership: Studies on firms, networks and institutions. Cheltenham: Edward Elgar.

Dunning, J., Lundan, S. (2008). Multinational Enterprises and The Global Economy. Edward Elgar Publishing Limited, UK.

Dunning, J. (2001). The eclectic (OLI) paradigm of international production: past, present and future, International Journal of the Economics of Business, 8(2), 173-190.

Dunning, J. (1988). The eclectic paradigm of international production: A restatement and some possible extensions, Journal of International Business Studies, 19(1), 1-31.

Fahy, J., Shipley, D., Neale, C. (1998). Motives and experience of international joint venture partners in Hungary, Journal of Business \& Industrial Marketing, 13(2), 155-165.

Hayek, F. (1941). The Pure Theory of Capital. The Ludwig von Misses Institute. Alabama. Retrieved 12 October 2020, from: https://cdn.mises.org/Pure\%20Theory\%20of\%20 Capital_4.pdf 
Hennart, J. F. (2009). Down with MNE-centric Theories! Market Entry and Expansion as the Bundling of MNE and Local Assets, Journal of International Business Studies, 40(9), 1432-1454.

Hill, C. W. L. (2007). International Business: Competing in The Global Marketplace. Irwin - McGraw-Hill, New York.

Investment Climate Reforms. An Independent Evaluation of World Bank Group Support to Reforms of Business Regulations. World Bank Group. (2015). Retrieved 28 October 2020, from: https:/ieg.worldbank.org/sites/default/files/Data/Evaluation/files/investment_climate_final.pdf.

Javorcik, B. S. (2004). Does Foreign Direct Investment Increase the Productivity of Domestic Firms? In Search of Spillovers through Backward Linkages, The American Economic Review, 94(3), 605-627.

Johnson, A. (2006). The Effect of FDI inflows on Host Country Economic Growth. Working Paper Series in Economics and Institutions of Innovation, 58.

Kahraman, C. (2011). Investment decision making under fuzziness, Journal of Enterprise Information Management, 24(2), 126-129.

Keynes, J. M. (1936). The General Theory of Employment, Interest and Money. Centre for Comparative and International Studies. Retrieved 2 October 2020, from: https:// www.files.ethz.ch/isn/125515/1366_KeynesTheoryofEmployment.pdf.

Narula, R. (2012). Do We Need Different Framework to Explain Infant MNEs from Developing Countries? Global Strategy Journal, 2(3), 188-204.

Oxelheim, L. (1993). The Global Race for Foreign Direct Investment: Prospects For The Future. Springer-Verlag Berlin Heidelberg.

Pike, R., Neale, B. (2006). Corporate Finance and Investment. Pearson Education Limited, England.

Ribau, C., Raposo. M., Moreira. A. (2015). Internationalisation of the firm theories: A schematic synthesis, Int. J. Business and Globalisation, 15(4), 528-554.

Shadow Economy Index for the Baltic Countries. Stockholm School of Economics. (2020). Retrieved 12 November 2020, from: https://www.sseriga.edu/shadow-economyindex-baltic-countries.

Shenkar, O. (2007). Foreign Direct Investment Theory and Application. Retrieved 15 October 2020, from: http://www.sagepub.com/sites/default/files/upm-binaries/ 18594_Chapter_3.pdf.

Verbeke, A., Kano, L. (2012). An Internalization Theory Rationale for MNE Regional Strategy, Multinational Business Review, 20(20), 135-152.

Verbeke, A., Kano, L. (2015). The New Internalization Theory and Multinational Enterprises from Emerging Economies: A Business History Perspective, The Business History Review, 89(3), 415-445.

Vernon, R. (1966). International investment and international trade in the product cycle, Quarterly Journal of Economics, 80(2), 190-207. 
https://oi.org/10.22364/hssl.29.1.06

\title{
ENERGY NEEDS OF THE AGRICULTURAL SECTOR AND THE POTENTIAL FOR ADDRESSING THEM
}

\author{
Inna Honcharuk ${ }^{1}$ \\ Vinnytsia National Agrarian University
}

\begin{abstract}
Agriculture has been considered as one of the priority countries' sectors in our research; the share of agriculture in the GDP of the world leading countries was investigated. The theoretical and practical aspects of the development of non-waste agricultural production are described. The author substantiates the actuality and potential of the introduction of waste-free technology that brings advantages for the enterprises and for the state too.

It is evaluated the assessment of international experience, which is the ability of agricultural waste to produce alternative energy sources. The theoretically available production potential of biogas and bioethanol from biomass of plant and animal origin has been calculated.

The immediate prospect of energy autonomy of agro-industrial production should be based on efficient production and use of biomass. It will help Ukraine to lower dependence on import of energy carriers, will shut down its transformation to raw appendage, will enable to recycle inside a scale resource, having gained thus of hundred thousand of work stations, growth of incomes of citizens and state budget. Production of biofuel at the given stage of development of the state acts as one of the basic accelerants of new global trends in agribusiness industry of Ukraine which will promote its stable development.
\end{abstract}

Keywords: autonomous energy management, agricultural production's waste, biofuels, Ukraine, EU.

\section{Introduction}

Climate change is one of the major problems of global development with potentially serious threats to the global economy and international security as a result of rising risks related to energy security, food and drinking water, the sustainable existence of ecosystems, risks to human health and life.

1 Contact Inna Honcharuk; dnistervnau2017@gmail.com; Vice-Rector for Scientific and Innovative Activities of Vinnytsia National Agrarian University, Sonyachna str. 3, Vinnytsia, Ukraine, 21008. 
Climate change has become one of the thorniest issues of the world economy and policy in the context of developing strategies for reducing greenhouse gas emissions and the gradual transition to low carbon development of all sectors of the economy and components of human life.

Renewable energy sources, combined with energy efficiency improvements, are the most powerful tool in decarbonising national and global economies.

The use of renewable energy has many potential benefits, including reducing greenhouse gas emissions, diversifying energy supplies, and decreasing the dependence on fossil fuel markets (particularly, oil and gas). The growth of renewable energy sources can also stimulate employment in the EU by creating jobs in new "green" technologies and ensuring energy autonomy in the agricultural sector through the use of agricultural waste for biofuels.

\section{Literature Review}

Nowadays, a number of studies of Ukrainian and foreign scientists are devoted to these issues, and a wide range of issues related to the influence of the use of the crop and livestock industry' waste for improving the AgroIndustrial Complex's efficiency and replenishing the energy balance of the country have been considered.

Among the scientists who have paid considerable attention to research on this subject, one can mention Angheluta, S. P., Burlacu, S., Diaconu, A., \& Curea, C. S. (2019), Fei Li, Shengkui Cheng, Huilu Yu, Dewei Yang (2016), Honcharuk, I. V., Tomashuk, I. V. (2017)., Kaletnik, G. M., Goncharuk, T. V. (2013), Kaletnik, G. (2018)., Lybæk, R., Christensen, T. B., \& Kjær, T. (2013), Trypolska, H. S., Diachuk, O. A., Podolets, R. Z., Chepeliev, M. H. (2016) and others.

There are several reasons for the current economic and social need for biofuel production and consumption in Ukraine, according to Kaletnik, G. (2018), starting from energy security considerations, diversifying national production, supporting innovation and ending with the economic and social efficiency of biofuel market development on the basis of high motivation for agrarian sector growth, positive social shift in rural employment growth and environmental security thanks to renewable energy sources.

As it has been noted by Angheluta, S. P., Burlacu, S., Diaconu, A., \& Curea, C. S. (2019), sustainable development can be achieved through the use of technologies which conserve the environment. One of these technologies is the production of energy from renewable energy sources, reduces the use of fossil fuels and affects the process of reducing greenhouse gas emissions into the atmosphere. 
The global livestock industry is growing, generating a large amount of waste. having reviewed waste from different viewpoints, Fei Li, Shengkui Cheng, Huilu Yu, Dewei Yang (2016), indicate that waste can be either important anaerobic fermentation materials for biogas production, or if they enter the environment without proper processing, be serious sources of soil and water systems contamination. Considering that in developing countries, the need for energy is a major threat to sustainable development and livelihoods, the production of renewable energy is essential.

Taking into account the modern theoretical research viewpoints, ideas and recommendations of these scientists, we should note that this topic is the subject to study and needs further scientific research.

\section{Material and methods}

Monographic, calculation, mathematical and statistical.

The calculation method is widely used in forecasting and planning the production and economic processes of development of the livestock industry. It involves developing several options for solving particular economic problems, evaluating them, and then choosing the best one. This method involves many techniques which ensure the relative accuracy of economic forecasts and targets for energy balance calculations.

The monographic method is used for a comprehensive and in-depth study of single phenomena, processes and the identification of causal relationships of their development. It is indispensable in the detailed study of individual observations of livestock waste.

The mathematical and statistical method uses rational methods of systematisation, processing and analysis of statistical observations data of mass phenomena in order to establish characteristic statistical patterns, use for scientific and practical conclusions and is based on the probabilistic nature of these phenomena.

\section{Results of research}

According to Eurostat, the share of renewable energy sources in the total energy balance of the EU member states has almost doubled since 2004 to 2018. In 2018, almost half (54.6\%) of energy in gross final energy consumption in Sweden was generated from renewable sources, Finland - 41.2\%, Latvia - 40.3\%, Denmark - 36.1\% and Austria - 33.4\%. The EU member states with the lowest share of renewable energy in the energy balance are the Netherlands (7.4\%), Malta (8.0\%), Luxembourg $(9.1 \%)$ and Belgium $(9.4 \%)$. By 2020 , the EU has aimed to reach $20 \%$ of gross 
final consumption of energy from renewable sources, and some countries have already crossed that line.

This positive development of alternative energy in the EU member states was driven by legally binding targets for increasing the share of renewable energy adopted by Directive 2009/28/EU on the promotion of the use of energy from renewable sources and the adoption of The Climate Change Plans to reduce carbon dioxide emissions.

According to the State Statistics Service of Ukraine, the share of energy supply from renewable sources in Ukraine in 2018 is only $4.6 \%$ (including hydropower $-1 \%$, biofuels and waste $-3.4 \%$, wind and solar $-0.2 \%$, and according to the Energy Strategy 2035, it should reach 8\% in 2020 (Figure 1). (Eurostat, State Statistics Service of Ukraine, 2018).

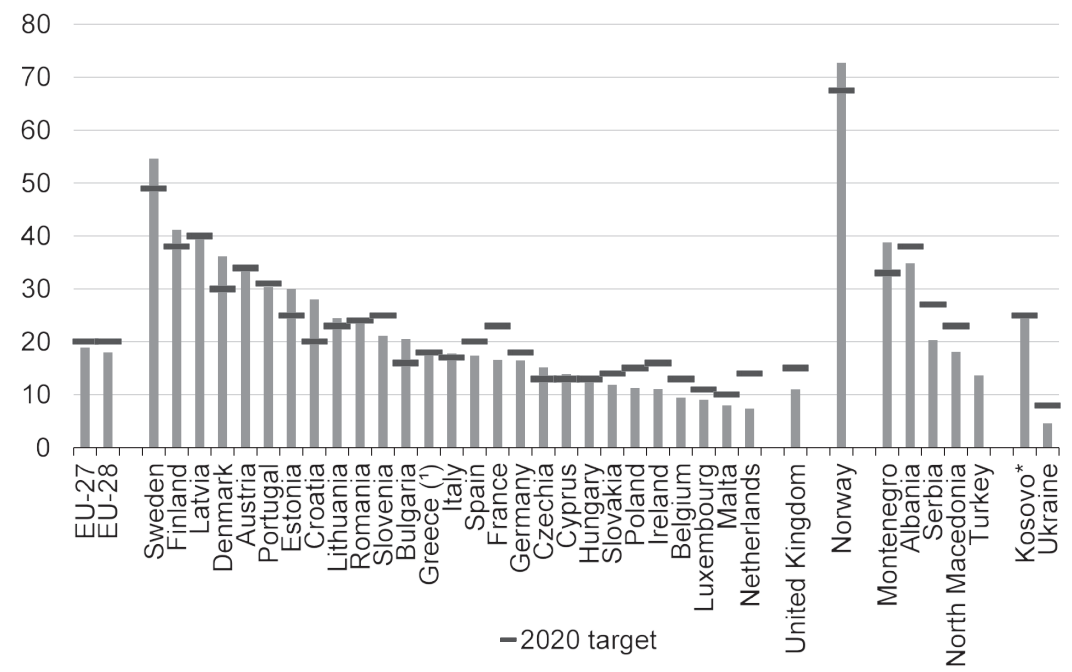

Figure 1. Share of energy from renewable sources, 2018

(\% of gross final energy consumption)

* This designation is without prejudice to positions on status, and is in line with UNSCR 1244/1999 and the ICJ Opinion on the Kosovo declaration of independence.

Source: Eurostat, State Statistics Service of Ukraine

Ukraine has considerable natural potential to make a "green" transition in all sectors of the economy, which remains untapped.

Agriculture occupies a small share in the final energy consumption structure (in 2018, as a whole, in the EU member states it was 2.68\%, in Ukraine - 1.695\%) (Figure 2) (Eurostat, State Statistics Service of Ukraine, 2018). However, this sector has sufficient potential to improve energy 
efficiency and transition to renewable energy sources and to assist other sectors of the economy through:

- increasing energy and resource efficiency of agricultural products and foodstuffs production;

- reducing the consumption of carbon intensive energy sources and maximising the use of renewable energy sources for switching the agro-industrial sector to full self-sufficiency in energy resources;

- rising the sustainable production of biomass, biofuels and other renewable energy sources to support the implementation of the "green" transition in other sectors of the economy.
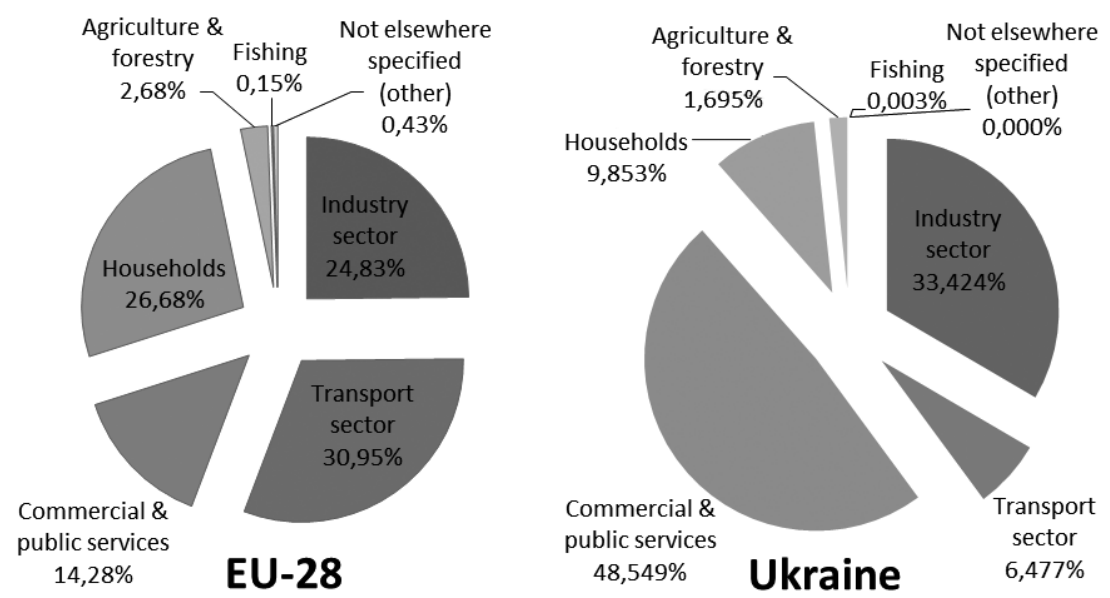

Figure 2. Share of final energy consumption by economic sectors, 2018 (\% of gross final energy consumption) Source: Eurostat, State Statistics Service of Ukraine

The EU agriculture and forestry play a significant role in the renewable energy supply. Renewable energy production from agriculture and forestry in the EU-27 reached 98.4 million tonnes of oil equivalent in 2010, accounting for $11.9 \%$ of total primary energy production and $59 \%$ of total renewable energy production. $60 \%$ of renewable energy from primary biomass sources in agriculture consists of biofuels (48\% from biodiesel energy crops and $12.2 \%$ from ethanol energy crops) and (39.8\% from agricultural biogas).

The contribution of agriculture to total primary energy production and to total renewable energy production increased by 1.8 percentage points between 2004 and 2010 (from $0.3 \%$ to $2.1 \%$ ) and by 8.4 percentage points (from $2.2 \%$ to $10.6 \%$ ), respectively. 
According to assessments of Directorate-General for Agriculture and Rural Development, in 2011, 6.1 million hectares of agricultural land in the EU-27, equivalent to $3.4 \%$ of the total agricultural land, was directly targeted at biomass production and energy production. The total area under cultivation of biomass and energy crops continues to increase in the EU-27.

Especially, in the agricultural sector, renewable energy production is very unevenly distributed across countries, with Germany (51\%) and France (13\%) producing $64 \%$ of all renewable energy in the EU-27 agricultural sector in 2010. The share of the agricultural sector in the production of total renewable energy, however, is the highest in Belgium (30.8\%). It is the lowest in Estonia $(0.3 \%)$. In the forest sector, differences between member states in the renewable energy production are less express. Germany (15.1\%), France (13\%), Sweden (12.3\%), Finland (9.5\%) and Poland (7.3\%) contributed $57 \%$ to the total EU renewable energy production in the EU-27 in 2010. The absolute contribution of forestry to total energy production is particularly high in Estonia $(97 \%)$, Latvia $(81.9 \%)$, Lithuania (76.5\%), Portugal (46.3\%), Finland (44.6\%), Luxembourg (40\%), Austria (35.7\%) and Sweden (30\%), while below the EU-27 average is in the United Kingdom (1\%) and the Netherlands (1.5\%).

According to the United Nations Economic Commission for Europe (UNECE), on average the share of agriculture in the GDP of the EU member states is 2 to $5 \%$, while in Ukraine, agriculture accounts for more than $12 \%$ of GDP and the dynamics of statistical data, shows that the AIC is gradually reaching the top (United Nations Economic Commission for Europe, 2019).

In 2018, according to the Food and Agriculture Organization, the gross harvest of basic crops accounts for more than $50 \%$ of the gross corn harvest by EU Member States, more than $43 \%$ for potatoes, and about $18 \%$ for wheat. Ukraine also has significant potential for livestock production. Despite the decline in livestock, the Ukrainian agricultural sector in 2018 holds more than 3530 thousand head of cattle, 6109 thousand head of pigs, 1309 thousand head of sheep and goats, a slight growth demonstrates poultry (over 203 million birds) (Table 1) (The Food and Agriculture Organization, 2018).

While conducting agricultural production, a large number of byproducts and agricultural wastes are formed which can be used to produce biofuels. These include all forms of plant material that can be used to produce energy: wood, grass and crops, forestry and livestock waste, as well as household and industrial waste not always of plant origin, but characterised by the same principles of their utilisation. 
Table 1. Key indicators of agro-industrial complex of Ukraine and EU in 2018

\begin{tabular}{|l|c|c|c|c|}
\hline Agricultural crops & Unit of measurement & Ukraine & \% to the EU & $\begin{array}{c}\text { the European } \\
\text { Union }\end{array}$ \\
\hline Gross harvest of basic agricultural crops: & \multicolumn{5}{|l|}{} \\
\hline wheat & thousand tons & 24652.84 & 17.86 & 138049.23 \\
\hline maize & thousand tons & 35801.05 & 51.73 & 69207.04 \\
\hline barley & thousand tons & 7349.14 & 13.02 & 56465.51 \\
\hline rye & thousand tons & 393.78 & 6.29 & 6263.53 \\
\hline sugar beet & thousand tons & 13967.70 & 11.68 & 119579.91 \\
\hline potatoes & thousand tons & 22503.97 & 43.07 & 52253.11 \\
\hline sorghum & thousand tons & 193.98 & 23.56 & 823.42 \\
\hline Livestock of farm animals: & thousand heads & 3530.800 & 3.99 & 88453.217 \\
\hline cattle & thousand heads & 6109.00 & 4.06 & 150321.266 \\
\hline pigs & thousand heads & 1309.300 & 1.18 & 111191.796 \\
\hline Sheep and Goats &
\end{tabular}

Source: The table created by the author according to the data of The Food and Agriculture Organization (FAO)

It should be noted that there is no unanimity among domestic and foreign scientists regarding the definition of "waste". In an economic encyclopaedia, waste is defined as a part of production that has been generated in the process of production, use or processing of agricultural raw materials and in long-term storage damages the environment.

"All objects of entrepreneurial activity are consumers of natural resources and conditions, producing in addition to the really necessary products and services, specific products - wastes", - I. H. Hrechanovska writes. "Wastes are an inevitable consequence of production, which are included in the cost of goods and themselves become a commodity, that is, a specific product of production, as they are involved in the structure of the system of production, consumption, accumulation", - said S. H. Shuntova.

From the viewpoint of V. I. Kerzhakov and O. M. Derykolenko, with the development of scientific and technological progress, the number of substances called "waste" will decrease, as technologies emerge, the raw material for which wastes generated earlier. In this case, it is secondary material resources. A similar position has been expressed by O. A. Novikov and H. A. Makhovykov, emphasising that waste is secondary material resources or secondary raw materials, and which, as a result of the process of restoration of consumer value, are transformed into a new object of 
work capable of addressing the needs of the new production process as much as possible.

It is necessary to agree with N. Korniakova that the concept of "waste" is multi-specific and can be considered on the basis of different approaches. In particular, given their physical properties, waste can be defined as any, mainly solids, substances, materials, or objects created in the course of human activity. In terms of economic characteristics, waste is a resource for other types of production. With regard to environmental properties, waste is considered to be a factor in the negative impact on the environment in the process of their formation, use or management. Depending on the quantitative and qualitative quantities of waste and their composition, such an impact can be defined as dangerous (Andreichenko, A. V., 2017).

Different definitions of waste category are contained in the regulations of Ukraine. In the Law of Ukraine "On Waste" (1998), waste means any substances, materials and objects that have been generated in the process of production or consumption, as well as goods (products) that have completely or partially lost their consumer properties and do not have subsequent use at the place of their formation or discovery and from which their owner disposes, intends or should be disposed of by disposal or disposal.

Considering the classification of wastes in agriculture, the author emphasises that the agro-industrial complex is an inter-sectoral complex that combines agriculture, industries providing agriculture with means of production, and industries for processing agricultural products.

A significant part of agricultural waste (more than $80 \%$ ) is made up of agricultural waste, plant and animal husbandry. By-products of agricultural production according to the "Waste Classifier" (DK 005-1996) (group 01) include:

- wastes from cereals production, vegetables and horticultural products;

- wastes from animal husbandry and livestock production;

- wastes from the production of mixed farm products;

- waste from rendering services in plant and animal husbandry;

- services specialised in the management of waste of agricultural production provided at the place of generation of waste.

The National Waste Management Strategy in Ukraine until 2030 states that traditionally agricultural waste in Ukraine is divided into animal husbandry, crop waste and agrochemical waste.

The agricultural production wastes involve: organic crop wastes; organic livestock and poultry waste; bio-waste (animal and poultry carcasses); residual amounts of fertilisers, chemicals and biologicals for plant protection, veterinary preparations. 
According to the Law of Ukraine "On State Support for Agriculture of Ukraine" (paragraph 2.15) of 2004, waste from the production of agricultural products (goods) also relates to agricultural products (goods).

This list includes:

- organic fertilisers and mixtures of organic and mineral fertilisers (if the proportion of organic fertilisers is more than $50 \%$ of the total weight of such mixtures);

- all biofuels and energy obtained from the processing of agricultural products (goods) and their wastes (biogas, biodiesel, ethanol, solid biofuels - if their production uses more than $50 \%$ of agricultural production (its wastes) of the total amount of electricity used, steam hot water, etc.).

Considering Ukraine's commitment to adopt EU technical standards and rules in a 10-year transition period, with regard to agro-industry, it is necessary to consider the classification of agricultural waste in the EU.

It is worth noting that the EU does not have separate legislation on agricultural waste. European Waste Catalogue has been developed for all EU Member States, in which agricultural waste is included in Chapter 2, Chapter 0201:

- 02 Waste from agriculture, horticulture, hunting, fishing and aquaculture primary production, preparation and processing;

- 0201 Primary production wastes;

- 020101 Sludge after washing and cleaning;

- 020102 Animal tissue waste;

- 020103 Waste from plant tissues;

- 020104 Plastic waste (except packaging);

- 020105 Waste of agrochemistry;

- 020106 Animal faeces, urine and pus (including spoiled straw);

- 020107 Waste from forest use;

- 020199 Other wastes.

Ukraine's legislation governing agricultural waste is expected to be brought into line with EU legislation by 2025.

From the author's point of view, it is advisable to classify agrarian and industrial complex waste according to the characteristics shown in Table 2 .

Today, agricultural waste, although a valuable raw material, is not always used. Agricultural enterprises do not plan indicators which would characterise their work on processing them into biofuels, increasing soil fertility, fertilising, especially organic. Therefore, there is a need for sound waste management.

Despite the range of environmental policies and programming adopted in Ukraine, waste management has not been properly reflected, despite the fact that waste can cause significant damage to public health and the environment. 
Table 2. Classification of agricultural wastes

\begin{tabular}{|c|c|}
\hline $\begin{array}{l}\text { According to sources } \\
\text { of origin }\end{array}$ & $\begin{array}{l}\text { - wastes from main industries; } \\
\text { - wastes from auxiliary industries; } \\
\text { - wastes from subsidiary industries }\end{array}$ \\
\hline $\begin{array}{l}\text { According to sources } \\
\text { of formation }\end{array}$ & $\begin{array}{l}\text { - plant: not the grain fraction of the crop (straw, stems), waste } \\
\text { of grain and seeds; buds of leaves of root tubers; } \\
\text { - animal: excrement of animals, waste of slaughterhouses; } \\
\text { - chemical }\end{array}$ \\
\hline $\begin{array}{l}\text { According to } \\
\text { the aggregate } \\
\text { condition }\end{array}$ & $\begin{array}{l}\text { - } \text { solid; } \\
\text { - rare; } \\
\text { - pasty; } \\
\text { - gaseous } \\
\end{array}$ \\
\hline $\begin{array}{l}\text { According to material } \\
\text { intensity }\end{array}$ & $\begin{array}{l}\text { - large tonnage; } \\
\text { - light tonnage }\end{array}$ \\
\hline $\begin{array}{l}\text { According to } \\
\text { the degree of } \\
\text { environmental impact }\end{array}$ & $\begin{array}{l}\text { - safe; } \\
\text { - dangerous (contain harmful substances having dangerous } \\
\text { properties) }\end{array}$ \\
\hline $\begin{array}{l}\text { According to } \\
\text { the method of disposal }\end{array}$ & $\begin{array}{l}\text { - on one's own; } \\
\text { - with the help of processing enterprises }\end{array}$ \\
\hline $\begin{array}{l}\text { According to } \\
\text { the further use }\end{array}$ & $\begin{array}{l}\text { - as fertilisers - secondary raw materials of agricultural } \\
\text { production that are used or can be used for the production } \\
\text { of organic fertilisers and restoration of soil fertility (manure } \\
\text { and animal manure, non-commercial part of the crop yield, } \\
\text { etc.); } \\
\text { - for food production through industrial processing; } \\
\text { - as forage; } \\
\text { - as fuel - biomass that is specially grown for energy needs (oil } \\
\text { and sugar-containing crops, algae, energy crops, etc.). }\end{array}$ \\
\hline $\begin{array}{l}\text { According to } \\
\text { processing methods }\end{array}$ & $\begin{array}{l}\text { - biological method; } \\
\text { - thermal method; } \\
\text { - mechanical method; } \\
\text { - chemical method }\end{array}$ \\
\hline
\end{tabular}

Source: The table created by the author according to the data of Andreichenko, (2017), Zamula, I. V., Bondarchuk V. V. (2013), Zarichanska, Ye. V. (2008).

Vegetable and animal wastes, mixed food waste; animal excrement, urine, pus occupy the main share in conducting economic activities of agricultural enterprises.

Waste utilisation is the predominant type of animal excrement, with this method eliminating twice as much waste as with the production of animal waste / mixed foods. Incineration is the most common way of dealing with vegetable waste, i.e. 418.7 thousand tons was burned for energy in 2018. The disposal of the three main types of agricultural waste is currently under-practiced in Ukraine (Table 3). 
Table 3. Generation and management of I-IV waste classes by categories of materials in agriculture of Ukraine in 2018 , thousand tons

\begin{tabular}{|l|c|c|c|c|}
\hline \multicolumn{1}{|c|}{ Indicator } & Created & Recycled & Burnt & $\begin{array}{c}\text { Removed to specially } \\
\text { designated places or objects }\end{array}$ \\
\hline $\begin{array}{l}\text { Animal waste and mixed } \\
\text { food waste }\end{array}$ & 607.5 & 295.3 & 9.4 & 1.7 \\
\hline Waste of plant origin & 7829.3 & 2638.2 & 418.7 & 154.0 \\
\hline $\begin{array}{l}\text { Animal excrement, urine } \\
\text { and pus }\end{array}$ & 3233.8 & 2300.6 & - & 72.0 \\
\hline
\end{tabular}

Source: table created by the author according to the State Statistics Service of Ukraine

Waste can be processed by biological, thermal, mechanical or chemical methods, depending on their characteristics and properties. For this purpose, it is advisable for the enterprise to conduct waste analysis by the methods of their processing, as well as on the grounds that it will occur at the expense of own or involved forces.

Biomass and agricultural waste used for energy purposes must be produced in accordance with sustainable development criteria. Such criteria include the prevention of negative environmental impacts, the promotion of the economic development of the region, the conservation of biological diversity, and the like.

Processing of by-products of crop and livestock products on biofuels would reduce the use of purchased energy resources, whose prices are constantly rising.

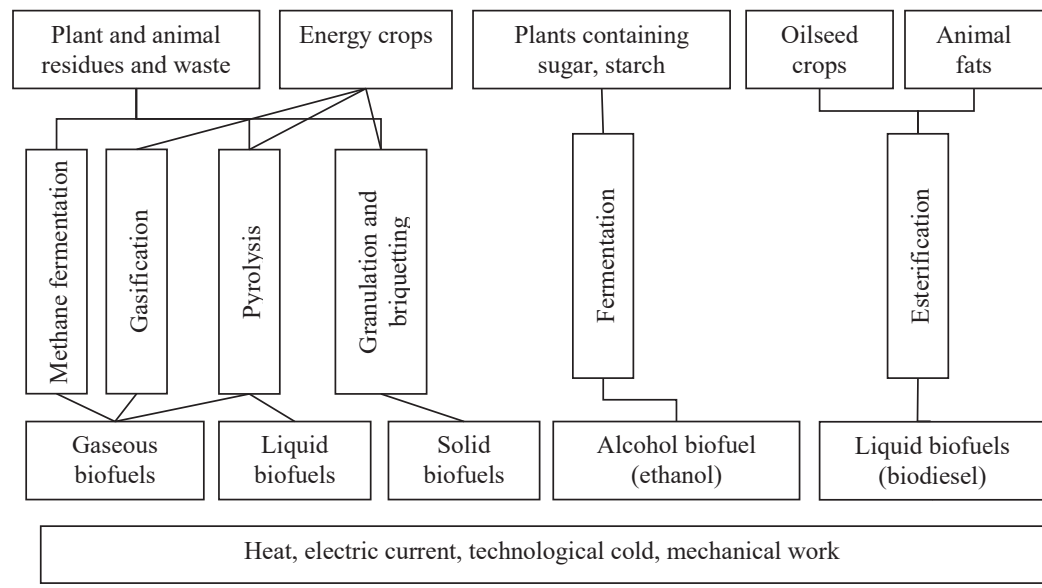

Figure 3. Scheme of the use of agricultural biomass for energy needs Source: The figure created by the author according to the Kaletnik, G. M., Goncharuk, T. V. (2013) 
According to the Law of Ukraine "On Alternative Fuels" №1391-XIV of 14.01.2000 biological fuels (biofuels) - solid, liquid and gaseous fuels made from biodegradable raw materials (biomass), which can be used as fuel or a component of other types fuel. Biofuels in Ukraine are classified as follows: liquid (ethanol, methanol, biodiesel), solid (wood, briquettes, fuel pellets, wood chips, straw, husks) and gaseous (biogas, hydrogen).

A block diagram of the use of agricultural biomass for energy needs is presented in Figure 3.

The utilisation of biomass and agricultural waste potential is one of the factors for the sustainable development of society, as well as the food, energy and environmental security of the state.

It is estimated that the biomass and waste production potential of the EU member states in 2020 may amount to 41048 million tons in agriculture, 74770 million tons of forestry, and 16901 million tons of waste. (Table 4).

Table 4. Assessment of biomass supply and waste from different sectors (million tons, \%), 2006-2020, EU-27

\begin{tabular}{|l|c|c|c|c|}
\hline \multirow{2}{*}{} & \multicolumn{4}{|c|}{ Biomass supply } \\
\cline { 2 - 5 } & \multicolumn{2}{|c|}{2015} & \multicolumn{2}{c|}{2020} \\
\cline { 2 - 5 } & Mtoe & $\%$ & Mtoe & $\%$ \\
\hline Agriculture & 28359 & 26.2 & 41048 & 30.9 \\
\hline Forestry & 67454 & 62.2 & 74770 & 56.4 \\
\hline Waste & 12627 & 11.6 & 16901 & 12.7 \\
\hline Total & 108440 & 100.0 & 132720 & 100.0 \\
\hline
\end{tabular}

Source: DG Agriculture and Rural Development / DG Energy - National Renewable Energy Action plans (NREAPs)

According to scientists' assessments, the total biomass potential available for bioenergy in Ukraine is 89950 thousand tons, and the used ones are 10466 thousand tons, or $11.6 \%$.

There are already several hundred enterprises operating in Ukraine for the production of pellets, briquettes, thousands of small, medium and large boilers for wood waste, firewood, chips, granules, more than 200 boilers and generators on bale straw, sunflower husk, corn stalks and others. raw materials. Plantations of energy willow (nearly 5 thousand hectares), miscanthus (about 2 thousand hectares) are cultivated (Roik, M. V, Ganzhenko, O. M., Tymoshchuk, V. L., 2014).

Biogas production potential is 20 billion $\mathrm{m}^{3}$ per year due to the use of livestock and biomass waste from bioenergy crop residues (Tables 6 and 7).

It should be noted that in the last 3-4 years in Ukraine in the field of bioenergy began to recover. A number of bioenergy, first of all, biogas 
projects of the European level have been implemented, in particular, in the companies - "Astarta", "Goodwelli Ukraine", "Ekoprod", "Rokytne", "Slavuta", "Nyva", "Dniprovska", "Hnidavskyi Sugar Factory" and others. The large agricultural enterprise "Myronivskyi Khliboproduct" is building a powerful $20 \mathrm{MW}$ biogas complex near Ladyzhyn of Vinnytsia region.

Table 6. Potential for biogas production from livestock wastes in Ukraine in 2018

\begin{tabular}{|c|c|c|c|c|c|c|c|c|}
\hline \multirow[t]{2}{*}{ Indicator } & \multirow{2}{*}{$\begin{array}{l}\text { Livestock, } \\
\text { million } \\
\text { animals }\end{array}$} & \multirow{2}{*}{$\begin{array}{c}\text { Manure } \\
\text { or litter } \\
\text { output, } \\
\text { m³ }^{3} / \\
\text { animal / } \\
\text { place / } \\
\text { year }\end{array}$} & \multicolumn{2}{|c|}{$\begin{array}{l}\text { Biogas output, } \mathrm{Nm}^{3} \text { / } \\
\text { t of substrate }\end{array}$} & \multirow{2}{*}{$\begin{array}{c}\text { Methane } \\
\text { content, } \\
\%\end{array}$} & \multicolumn{2}{|c|}{$\begin{array}{c}\text { Biogas } \\
\text { output, } \\
\mathrm{Nm}^{3} / \\
\text { year }\end{array}$} & \multirow{2}{*}{$\begin{array}{c}\begin{array}{c}\text { Bio- } \\
\text { methane } \\
\text { output, } \\
\mathrm{Nm}^{3} \text { / } \\
\text { year }\end{array} \\
\text { min }\end{array}$} \\
\hline & & & $\begin{array}{l}\text { Meas- } \\
\text { urement } \\
\text { range* }^{*}\end{array}$ & Average & & $\min$ & $\max$ & \\
\hline Cattle & 3.5 & $7.5-21.0$ & $20-30$ & 25 & 60 & 525 & 2205 & 315 \\
\hline Pigs & 6.2 & $1.2-6.0$ & $20-35$ & 28 & 65 & 148.8 & 1302 & 96.7 \\
\hline Poultry & 204.8 & $\begin{array}{c}7.5(\mathrm{x} 100 \\
\text { animal } \\
\text { place per } \\
\text { year) }\end{array}$ & $130-270$ & 140 & 64 & 1997 & 4147 & 1278.1 \\
\hline
\end{tabular}

Source: the table is formed by the author according to the data of the State Statistics Service and own calculations and own calculations

For biogas, corn silage, sugar beet pulp, animal manure, poultry manure, etc. are used. Without violating food security, the domestic agroindustrial complex can use part of the acreage for biomass production for biofuel production. The potential for biogas and bioethanol production from energy crops was calculated based on the acreage utilisation for their crops in 2018.

Table 7. Potential output of biogas and biomethane from bioenergetic plants in Ukraine in 2018

\begin{tabular}{|l|c|c|c|c|c|c|}
\hline $\begin{array}{c}\text { Agricultural } \\
\text { crops }\end{array}$ & $\begin{array}{c}\text { Potential } \\
\text { of sown } \\
\text { area, } \\
\text { million ha }\end{array}$ & $\begin{array}{c}\text { Yield } \\
\text { capacity, } \\
\mathbf{t} / \mathbf{h a}\end{array}$ & $\begin{array}{c}\text { Biogas } \\
\text { output, } \\
\mathbf{m}^{\mathbf{3}} / \mathbf{t}\end{array}$ & $\begin{array}{c}\text { Biomethane } \\
\text { output, } \\
\mathbf{m}^{3} / \mathbf{t}\end{array}$ & $\begin{array}{c}\text { Biogas } \\
\text { output, } \\
\text { billion } \\
\mathbf{m}^{3} / \text { year }\end{array}$ & $\begin{array}{c}\text { Bio-methane } \\
\text { output, } \\
\text { billion } \\
\mathbf{m}^{\mathbf{3}} / \text { year }\end{array}$ \\
\hline Corn for silage & 4.5 & 80 & 16.0 & 8.5 & 72 & 38.25 \\
\hline Sugar beets & 0.2 & 50.8 & 10.9 & 6.0 & 2.18 & 1.2 \\
\hline Sugar Sorghum & 0.04 & 4.6 & 17.6 & 8.8 & 0.7 & 0.35 \\
\hline Total & 4.74 & & & & 44.88 & 39.8 \\
\hline
\end{tabular}

Source: the table is formed by the author according to the data of the State Statistics Service and own calculations 
A number of sugar mills produce molasses bioethanol and pulp biogas, as well as organic solvents, feed additives, organic bard fertilisers, microbiological preparations and other products. (Marchenko, V. M., Kit, A. V., 2018).

Table 8. Ethanol production potential of different raw materials in Ukraine in 2018

\begin{tabular}{|l|c|c|c|c|c|}
\hline $\begin{array}{c}\text { Crop (raw } \\
\text { material) }\end{array}$ & $\begin{array}{c}\text { Sown areas, } \\
\text { thousand } \\
\text { hectares }\end{array}$ & $\begin{array}{c}\text { Yield, } \\
\text { centner } / \mathbf{k g}\end{array}$ & $\begin{array}{c}\text { Output of } \\
\text { ethanol from } \\
\mathbf{1} \text { ton of raw } \\
\text { material, } \mathbf{~}\end{array}$ & $\begin{array}{c}\text { Ethanol yield } \\
\text { per } \mathbf{1} \text { ha, } \mathbf{~} / \text { ha }\end{array}$ & $\begin{array}{c}\text { Ethanol } \\
\text { production } \\
\text { potential per } \\
\text { year, ppm }\end{array}$ \\
\hline sugar beets & 276 & 508.5 & 100 & 5085 & 1.2 \\
\hline corn (grain) & 4579.7 & 78.4 & 416 & 3261 & 12.8 \\
\hline wheat & 6614.0 & 37.3 & 395 & 1473 & 8.3 \\
\hline barley & 2492.2 & 29.6 & 370 & 1095 & 2.3 \\
\hline potato & 1319 & 324 & 114 & 3694 & 4.1 \\
\hline rye & 148.7 & 26.6 & 340 & 904 & 0.1 \\
\hline
\end{tabular}

Source: the table is formed by the author according to the data of the State Statistics Service and own calculations

Nowadays the renewable energy market is developing rapidly and is an element of modern, waste-free manufacturing in the industry as a whole, and of the agro-industrial complex in particular. For businesses that have agricultural or food waste, it is possible to reduce the amount of costs in the article "Fuel and electricity for technological purposes", which can significantly reduce the cost of all products manufactured at the enterprise. (Kulakovska, T. A., Shekera, S. S., 2012).

In 2018, Ukrainian agricultural enterprises purchased oil products and energy materials in the amount of 109.3 thousand tons gasoline, 1,445 thousand tons diesel fuel, 4,2 thousand tons fuel oil, 261.9 thousand tons oils and oils, 57.6 thousand tons coal, 298.9 million $\mathrm{m} 3$ of natural gas. In spite of the fact that the volume of purchased fuel and lubricants by agricultural enterprises by years differs in volume by a small amount, however, the total cost of purchased fuel and lubricants and other energy resources increases significantly annually.

This is due to the fact that despite periodic significant drops in oil prices, sometimes even 1.5-2 times, oil traders not only do not proportionally reduce the price, keep it high and even increase it (Figure 4).

According to the State Statistics Service of Ukraine, the price of gasoline in 2018 has almost doubled (in 2018 by UAH 9548,3 / t, compared to 2015); a similar trend is observed for diesel fuel (increased in 2018 compared to 2015 by $88892,9 \mathrm{UAH} / \mathrm{t}$ ), natural gas (price increased by $2596,3 \mathrm{UAH} /$ thousand $\mathrm{m} 3$ ) and other types of energy resources (Table 9). 


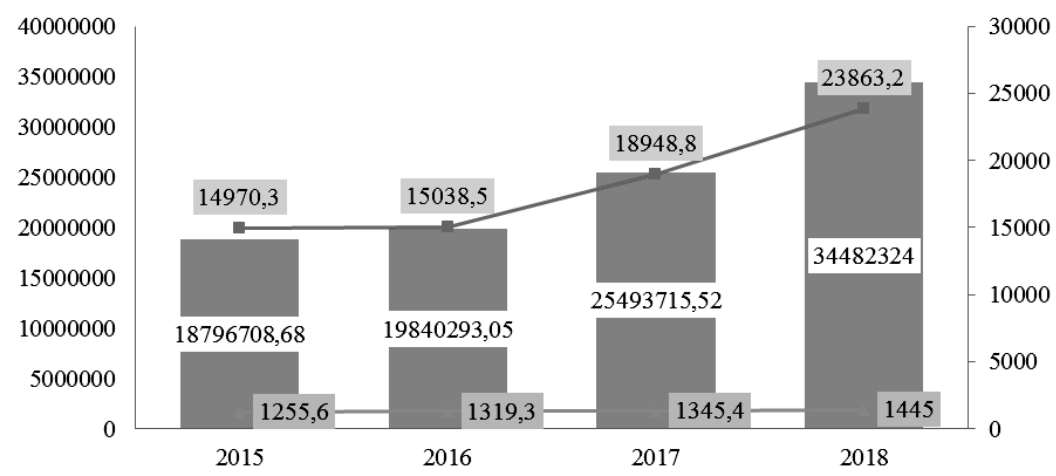

Costs for the purchase, thousand UAH $\rightarrow$-Price, $\mathrm{UAH} / \mathrm{t}$

- Volume of the purchase, thousand tons

Figure 4. Costs for the purchase of diesel fuel in Ukraine Source: State Statistics Service of Ukraine

Table 9. Purchase of petroleum products and energy materials by the agricultural enterprises of Ukraine for 2015-2018

\begin{tabular}{|c|c|c|c|c|c|c|}
\hline Indicator & $\begin{array}{c}\text { Unit of } \\
\text { measurement }\end{array}$ & 2015 & 2016 & 2017 & 2018 & $\begin{array}{c}\text { Deviation, } \\
+/-\end{array}$ \\
\hline \multicolumn{7}{|c|}{ Volume } \\
\hline Gasoline & thousand tons & 132.8 & 130.3 & 125.3 & 109.3 & -23.5 \\
\hline Diesel & thousand tons & 1255.6 & 1319.3 & 1345.4 & 1445.0 & 189.4 \\
\hline Fuel oil & thousand tons & 1.8 & 2.0 & 2.9 & 4.2 & 2.4 \\
\hline Oils & thousand centres & 221.7 & 240.5 & 233.9 & 261.9 & 40.2 \\
\hline Coal & thousand tons & 60.6 & 65.0 & 74.5 & 57.6 & -3 \\
\hline Natural gas & million $\mathrm{m}^{3}$ & 285.0 & 338.4 & 330.1 & 298.9 & 13.9 \\
\hline \multicolumn{7}{|c|}{ Price } \\
\hline Gasoline & hrn/t & 17575.5 & 18601.9 & 22750.0 & 27123.8 & 9548.3 \\
\hline Diesel & hrn/t & 14970.3 & 15038.5 & 18948.8 & 23863.2 & 8892.9 \\
\hline Fuel oil & hrn/t & 9310.8 & 10633.0 & 13347.4 & 15962.8 & 6652 \\
\hline Oils & hrn/c & 3468.2 & 3543.1 & 3984.3 & 3991.5 & 523.3 \\
\hline Coal & hrn/t & 1424.5 & 1870.4 & 2526.2 & 3088.7 & 1664.2 \\
\hline Natural gas & hrn/t rpH/th. $\mathrm{m}^{3}$ & 6764.7 & 6670.2 & 7496.1 & 9361.0 & 2596.3 \\
\hline
\end{tabular}

Source: table created by the author according to the State Statistics Service of Ukraine

In the structure of direct costs for the production of agricultural products of all types of the agrarian sector's economic entities, the purchase of petroleum products and energy materials is $10,8 \%$ in the cost structure; 
for small farms, the purchase of fuel and lubricants is even more $-14,9 \%$ (Table 10).

Table 10.Cost structure of agricultural production (services) in all enterprises in $2018^{1}$

\begin{tabular}{|c|c|c|c|c|}
\hline \multirow[b]{2}{*}{ Types of costs } & \multicolumn{2}{|c|}{ All enterprises ${ }^{2}$} & \multicolumn{2}{|c|}{ Including private farms } \\
\hline & $\begin{array}{l}\text { Million } \\
\text { UAN }\end{array}$ & $\begin{array}{c}\% \text { to } \\
\text { the total } \\
\text { costs }\end{array}$ & $\begin{array}{c}\text { Million } \\
\text { UAN }\end{array}$ & $\begin{array}{l}\% \text { to } \\
\text { the total } \\
\text { costs }\end{array}$ \\
\hline Costs - total & 442993.4 & 100.0 & 68397.4 & 100.0 \\
\hline Direct costs - total & 247997.2 & 56.0 & 41524.8 & 60.7 \\
\hline \multicolumn{5}{|l|}{ including } \\
\hline seeds and planting materials & 35963.5 & 8.1 & 7585.1 & 11.1 \\
\hline fodder & 52036.9 & 11.7 & 2434.2 & 3.6 \\
\hline including purchased fodder & 22866.8 & 5.2 & 1195.8 & 1.7 \\
\hline other agricultural products & 6496.8 & 1.5 & 330.9 & 0.5 \\
\hline inorganic fertilisers & 57695.7 & 13.0 & 13150.0 & 19.2 \\
\hline oil products & 39035.6 & 8.8 & 9362.3 & 13.7 \\
\hline electric power & 3920.3 & 0.9 & 424.4 & 0.6 \\
\hline fuel & 4898.6 & 1.1 & 385.2 & 0.6 \\
\hline $\begin{array}{l}\text { spare parts. repair and construction } \\
\text { materials to repair }\end{array}$ & 21335.5 & 4.8 & 4266.8 & 6.2 \\
\hline Labour costs & 25234.4 & 5.7 & 3467.8 & 5.1 \\
\hline Other direct costs - total & 95016.8 & 21.4 & 15597.1 & 22.8 \\
\hline \multicolumn{5}{|l|}{ including } \\
\hline deductions on the social purposes & 5533.7 & 1.2 & 803.1 & 1.2 \\
\hline \multicolumn{5}{|l|}{ rent payments for } \\
\hline land shares (stocks) & 43952.0 & 9.9 & 7308.6 & 10.7 \\
\hline property shares & 429.5 & 0.1 & 63.6 & 0.1 \\
\hline depreciation of fixed assets & 25752.9 & 5.8 & 5566.8 & 8.1 \\
\hline Indirect costs - total & 74745.0 & 16.9 & 7807.7 & 11.4 \\
\hline \multicolumn{5}{|l|}{ including } \\
\hline $\begin{array}{l}\text { payment of services and job of other } \\
\text { organizations }\end{array}$ & 34233.5 & 7.7 & 4082.0 & 6.0 \\
\hline
\end{tabular}

${ }^{1}$ Data exclude the temporarily occupied territory of the Autonomous Republic of Crimea, the city of Sevastopol and a part of temporarily occupied territories in the Donetsk and Luhansk regions

2 Information is compiled by enterprises with the main economic activity "Growing of nonperennial crops", "Growing of perennial crops", "Plant propagation", "Animal production", "Mixed farming", "Support activities to agriculture and post-harvest crop activities" and "Processing and preserving of poultry meat" (codes 01.1-01.6 and 10.12 by NACE Rev. 2 2006). 
Costs for the purchase of fuel and lubricants in agricultural production are increasing every year and this leads to an increase in the cost of manufactured agricultural products.

Having analysed the above estimates of existing biomass and waste potential, the increase in biofuel production from agricultural waste will solve the problem of purchasing expensive fossil fuels by replacing them with biofuels. This will increase the competitiveness of domestic agricultural products by reducing the cost of production of agricultural products. Such waste-free technologies contribute to the sustainable development of society and provide energy autonomy for the agricultural sector.

Due to the difficult economic situation of Ukraine, caused by both internal and external problems, it is difficult to realise the very fast pace of bioenergy development. There remain many unresolved and complex problems in Ukrainian bioenergy. There is practically no clear strategy for the development of bioenergy at the state level, there is a strong opposition in the country from the leading energy companies and their lobby for the use of biological fuels, especially bioethanol and biogas, which are competitive for them. The volume of public and private investment in bioenergy, especially in the scientific and technical sphere, is still insufficient. The economic problems of bioenergy, especially incentive measures for the construction and further development of bioenergy facilities, remain virtually unsolved.

\section{Conclusions and Proposals}

In order to implement autonomous energy management of the agrarian sector and reduce the energy dependence of other sectors of the Ukrainian economy, it is necessary to take a number of measures and introduce a state policy on:

- harmonisation of legislative and regulatory acts of Ukraine with EU legislation on the promotion of the use of energy produced from renewable sources;

- promoting the development of economic activities aimed at reducing methane emissions from animal husbandry by installing biogas reactors, as well as from other primary products of the agroindustrial complex;

- expansion of sustainable biomass production for energy supply, which will increase the volume of biomass from agriculture and forestry (timber, agricultural waste and agricultural products, energy crops) for heat and electricity production and replacement of fossil fuels; 
- development and implementation of biomass conversion technologies by increasing the rate of development of the latest biomass conversion technologies and developing the market for such technologies for biofuels production and so on.

\section{REFERENCES}

1. Eurostat. Available at: https://ec.europa.eu/eurostat.

2. Official site of the State Statistics Service of Ukraine. Statistical information. Available at: http://www.ukrstat.gov.ua/.

3. The Food and Agriculture Organization (FAO). Available at: http://www.fao.org/faostat/ru/\# compare.

4. Andreichenko, A. V. (2017). Waste typology in agriculture: domestic and European experience. Economic Space, 124: 67-76.

5. Zamula, I. V., Bondarchuk V. V. (2013). Agricultural Waste Accounting: An Ecological Vector. Problems of Theory and Methodology of Accounting, Control and Analysis, 3 (27): 85-96.

6. Zarichanska, Ye. V. (2008). Clarification of the main classification characteristics of waste in the economic system. Proceedings of the IV Scientific-Practical Conference: 567-571. Available at: http://ea.donntu.edu.ua:8080/jspui/handle/ $123456789 / 9566$.

7. DG Agriculture and Rural Development / DG Energy - National Renewable Energy Action plans (NREAPs). Available at: https://ec.europa.eu/energy/topics/renewable-energy/national-renewable-energy-action-plans-2020_en?redir $=1$.

8. Kaletnik, G. M. (2018). Diversification of production of biofuel - as the basis of maintenance of food, power, economic and environmental safety of Ukraine. Bulletin of Agricultural Science, №11(788): 169-176. Available at: https:/doi. org/10.31073/agrovisnyk201811-21.

9. Roik, M. V, Ganzhenko, O. M., Tymoshchuk, V. L. (2014). The concept of biogas production from bioenergy plants in Ukraine. Bioenergy, 2. Available at: file:///C:/ Users/user/Downloads/Bioen_2014_2_2\%20(1).pdf.

10. Marchenko, V. M., Kit, A. V. (2018). Analysis of production potential of bioethanol from sugar beet in Ukraine. Agrosvit. Available at: http://www.agrosvit.info/ pdf/22_2018/5.pdf.

11. Kulakovska, T. A., Shekera, S. S. (2012). Analysis of the Ukrainian market of biological fuel from wastes of agricultural and industrial enterprises. Cereal products and compound forage,

12. State Classifier of Ukraine. Waste Classifier DK 005-96. Available at: http://plast. vn.ua/DK005-96.html.

13. Government of Ukraine (2004). The Law of Ukraine «Про державну підтримку сільського господарства України». (On State Support for Agriculture of Ukraine.) Information of the Verkhovna Rada of Ukraine, 49: 527. Available at: https://zakon.rada.gov.ua/laws/show/1877-15. 
14. Government of Ukraine (1998). The Law of Ukraine «(On Wastes) Про відходи». Information of the Verkhovna Rada of Ukraine, 36-37: 242. Available at: https:// zakon.rada.gov.ua/laws/show/ru/187/98-\%D0\%B2\%D1\%80.

15. Європейський каталог відходів. Available at: https://www.sustainabilityexchange.ac.uk/the_european_waste_catalogue_ewc.

16. Government of Ukraine (2000). The Law of Ukraine «Про альтернативні види палива» (On alternative fuels). Information of the Verkhovna Rada of Ukraine, 12: 94. Available at: https://zakon.rada.gov.ua/laws/show/1391-14.

17. Government of Ukraine (2017). Національна стратегія відходами в Україні до 2030 року. (Ukrainian National Waste Management Strategy until 2030) Available at: https://zakon.rada.gov.ua/laws/show/820-2017-\%D1\%80.

18. Kaletnik, G. M., Goncharuk, T. V. (2013). Innovative support for the development of the biofuel industry: world and national experience. Business Inform, 9: 155-160. Available at: http://www.irbis-nbuv.gov.ua/cgi-bin/irbis_nbuv/cgiirbis 64.exe?I21DBN $=$ LINK\&P21DBN $=$ UJRN \&Z21ID $=\& S 21 R E F=10 \& S 21 \mathrm{CNR}=20 \overline{8}$ $\mathrm{S} 21 \mathrm{STN}=1 \& \mathrm{~S} 21 \mathrm{FMT}=\mathrm{ASP} \_$meta $\& C 21 \mathrm{COM}=\mathrm{S} \& 2 \_\mathrm{S} 21 \mathrm{P} 03=\mathrm{FILA}=\& 2 \_\mathrm{S} 21 \mathrm{STR}=$ binf_2013_9_26.

19. Honcharuk, I. V., Tomashuk, I. V. (2017). Influence of ecological and economic factor on peculiarities of organizational and economic mechanism of utilization of the resource potential of rural territories. Economy. Finances. Management: topical issues of science and practice, 4: 52-62. Available at: http://repository.vsau.org/ getfile.php/15770.pdf.

21. Angheluta, S. P., Burlacu, S., Diaconu, A., \& Curea, C. S. (2019). The Energy from Renewable Sources in the European Union: Achieving the Goals. European Journal of Sustainable Development, 8(5): 57-65. https://doi.org/10.14207/ejsd.2019.v8n5p57.

22. Lybæk, R., Christensen, T. B., \& Kjær, T. (2013). Enhancing the Transition Capability of Danish Biomass Technology By Applying a Futures Study Backcasting Methodology on the Biogas Sector. European Journal of Sustainable Development, 2(4): 37-50. https://doi.org/10.14207/ejsd.2013.v2n4p37.

23. Fei Li, Shengkui Cheng, Huilu Yu, Dewei Yang (2016). Waste from livestock and poultry breeding and its potential assessment of biogas energy in rural China. Journal of Cleaner Production, 126: 451-460. https://doi.org/10.1016/j. jclepro.2016.02.104.

24. Trypolska, H. S., Diachuk, O. A., Podolets, R. Z., Chepeliev, M. H. (2016). Biogas projects in Ukraine: prospects, consequences and regulatory policy. Economics and forecasting, 2: 111-134. https://doi.org/10.15407/eip2018.02.111. 


\title{
AGILE APPROACH VERSUS CLASSICAL APPROACH IN PROJECT MANAGEMENT WITH REGARD TO LEADERSHIP CHANGE
}

\section{Nurgul Janowski ${ }^{1}$}

Faculty of Business, Management and Economics, University of Latvia, Riga, Latvia

\begin{abstract}
Agility is a term which is modern and present nowadays in all levels and areas of companies. The increasingly changing situation on the market and the fundamental uncertainty forces companies to be more flexible and this flexibility cannot be covered only by classical existing approach. Therefore, this article results from the need to introduce a new approach and to compare it with the existing classical approach.

This article gives a definition for agility, discusses different scientific theories about agility and describes why agile approach is necessary in companies and where the differences between the previous classic approach and the agile approach is. The change has to be supported by leadership and for this reason in this article are introduced leadership types that support the agile change in the company.
\end{abstract}

Keywords: agility, leadership, change, classic approach, project management, comparison

\section{Introduction}

The world is getting faster, and more complex and traditional practices can no longer compete in companies. Shifting economic forces, accelerated urbanisation, technological breakthroughs therefore present today's companies with unprecedented challenges.

The increasing speed at which markets, products, technologies and subsequently also business models change, means that a company's ability to change becomes a critical success factor. A constantly changing market situation and the accompanying trend towards digitalization demand companies a high degree of flexibility to continuously adapt and optimise their strategy and its implementation.

1 Contact: Nurgul Janowski; nurgul.janowski@gmx.de; University of Latvia, Kunigundenstr. 28, Munich, 80802, Germany. 
When it comes to becoming a more agile company, it is above all company leaders that are crucial. A leader needs a lot of courage and foresight to start a change early enough. A change that questions the existing classical approach and deals with new business models based on agility and thus to remain successful in the medium and long term.

Leadership is a very important part for agility in companies and plays the main role in its implementation and cares also for the sustainability. In addition, leadership means not only limiting oneself to the methodological and business topics, but initiating the necessary cultural change with a changed mindset and being open to the challenges that arise.

Traditional organisations are not designed for the dynamic development of the changing economy today. The following study shows the direct connection between agility and success: agile companies achieve aboveaverage margins up to five times more often and grow faster than their competitors. Over $40 \%$ of all agile companies are top performers, only $24 \%$ develop below average. In the case of rather sluggish organisations, on the other hand, the risk of being at the bottom is increased: more than half of the rigid organisations develop below average. Only $18 \%$ of them are above average success ${ }^{2}$.

The purpose of this article is to give a definition of agility, to introduce different theories about agility and related leadership, as well as to do a comparison between the agile approach and the classical approach. In the comparison will be considered the changing role of the leadership.

\section{Definition of Agility}

Agility became popular in the early 1990s through publications on production strategies in the $21^{\text {st }}$ century ${ }^{3}$. The popularity of agility in the decade increased primarily due to its use in $\mathrm{IT}^{4}$. What has been new since the beginning of the 2000s is the bundling of different methods within frameworks ${ }^{5}$.

${ }^{2}$ Roghé F., Scholz S., Schudey A.: Organisation im 21. Jahrhundert. Eine Studie identifiziert sechs Erfolgsfaktoren. Zeitschrift Führung und Organisation. www.wisonet.de. 04/2017 (86. Jg.) p. 244-249.

${ }^{3}$ Förster, K., \& Wendler, R.: Theorien und Konzepte zu Agilität in Organisationen. Dresdner Beiträge zur Wirtschaftsinformatik, 63(12), 1, 2012.

${ }^{4}$ Mergel, I.: Agile Innovation management in government: A research agenda. Government Information Quarterly, 33(3), 2016, p. 518.

${ }^{5}$ Williams, L., \& Cockburn, A.: Agile Software Development: It's about Feedback and Change. Computer, 36(6), 39-43, 2003, p. 40. 
According to Highsmith the term "agile" is intended to express the idea that the management and steering of projects and processes must be dynamic and flexible and that it must also be possible to implement requirements and react to changes in turbulent and rapidly changing market conditions 6 .

According to Termer and Nissen, movement in the context of agility means that a person's position in relation to his or her environment changes over time. Agility means creating this flexibility out of one's own drive, usually even before a situation or an event makes this mobility necessary ${ }^{7}$. Agility requires a high level of communication in a network of individuals. For this reason, Appelo also attributes a high degree of networking and flexibility and trust are based on the relationship and communication between individuals.

Agility requires a high level of communication in a network of individuals. For this reason, Appelo also attributes a high degree of networking and flexibility and trust are based on the relationship and communication between individuals ${ }^{8}$.

Short, iterative development cycles should create added value for customers. The implementation is self-organised, which is also described as the core of agility ${ }^{9}$. Agility requires a constant speed of work and the proactive integration of the customer into the development process in order to react quickly to changing framework conditions ${ }^{10}$.

Teams work synchronously on a common goal and achieve its sub-goals through incremental product deliveries. Agility requires a high degree of team discipline which is driven indirectly by team members ${ }^{11}$.

Agility is also described as "radical employee orientation"12. Some elements (customer loyalty) are not a new phenomenon, but rather

${ }^{6}$ Highsmith, J. A.: Agile project management; creating innovative products; 1 . Auflage; Addison-Wesley Longman; Amsterdam; 2004; p. 16.

${ }^{7}$ Termer F., Nissen V.: Zum Begriff der Agilität - Betrachtungen und Implikation ausetymologischer Perspektive, 2014.

${ }^{8}$ Williams, L., \& Cockburn, A.: Agile Software Development: It's about Feedback and Change. Computer, 36(6), 39-43, 2003.

${ }^{9}$ Förster, K., \& Wendler, R.: Theorien und Konzepte zu Agilität in Organisationen. Dresdner Beiträge zur Wirtschaftsinformatik, 63(12), 1, 2012, p. 20.

${ }^{10}$ Dingsøyr, T., \& Lassenius, C.: Emerging themes in agile software development: Introduction to the special section on continuous value delivery. Information and Software Technology, 2012, p. 1214.

${ }^{11}$ Siakas, K. V., \& Siakas, R.: The Agile Professional Culture: A Source of Agile Quality. Software Process Improvement and Practice, 12, 2012, p. 607.

${ }^{12}$ Häusling, A., Rutz, B., Oimann, K., \& Oebbeke, B.: Agil anpassen! Personalmagazin, 2014, p. 18. 
an evolution of best practices that have been continually adapted and improved ${ }^{13}$. The previous focus on automation and standardisation increases the effectiveness of an organisation, but prevents innovations that are not guided by machines in the form ${ }^{14}$.

The paradox in the classic way of thinking is the natural, inherent uncertainty in processes, which cannot be compensated by even more advance planning. Robust planning necessary for this is only possible if all knowledge is available in advance. However, this does not correspond to reality.

It is clear to note that the definition is not yet clear, and one cannot yet say what is agile. It is also unclear which framework for agility really fits the definition of agile companies ${ }^{15}$.

The foundation is therefore the four agile values and 12 agile principles of the agile manifesto. The Agile Manifesto was written by 17 software developers. In addition, there are agile methods that primarily come from software development, but are increasingly being used as a management method, such as Scrum ${ }^{16}$. Rigby, Sutherland and Takeuchi state, almost 20 years after the Agile Manifesto, that agility has brought about a revolutionary change in software development ${ }^{17}$.

The continuous expansion within IT, as well as in other industrial sectors demonstrates the interest in shortened reaction times. This requires the adaptation of agile methods to the new requirements. This is increasingly leading to a growing acceptance of agility as a management concept.

From the application level agile principles are transferred for example to the development and production of physical parts in automotive engineering ${ }^{18}$. Besides product development, agile processes can also be implemented in sales, marketing, strategic planning, and logistics. Less

${ }^{13}$ Miller, G. G.: TOOLS '01 Proceedings of the $39^{\text {th }}$ International Conference and Exhibition on Technology of Object-Oriented Languages and Systems: The Characteristics of Agile Software Processes (pp. 385-387). Washington, DC, 2001, p. 387.

${ }^{14}$ Stoffel, M. 2016: Leadership 4.0 - Unternehmen brauchen ein neues "Betriebssystem". In von C. Au (Ed.), Wirksame und nachhaltige Führungsansätze (pp. 205-222), Wiesbaden: Springer.

${ }^{15}$ Förster, K., \& Wendler, R.: Theorien und Konzepte zu Agilität in Organisationen. Dresdner Beiträge zur Wirtschaftsinformatik, 2012, p. 7.

${ }^{16}$ Alegría and Bastarrica (2006, pp. 5-10); Häusling and Wiegand (2012, p. 19) Häusling, A., \& Wiegand, S. (2012). Agil dank Scrum. Personalmagazin, 06, 18-20.

${ }^{17}$ Rigby, D. K., Sutherland, J., \& Takeuchi, H. (2016). Embracing Agile. Harvard Business Review.

${ }^{18}$ Erretkamps, H., \& Oswald, A.: Der agile Produktentstehungsprozess - mehr als ein Prozess. In R. Wagner, \& N. Grau (Eds.), Basiswissen Projektmanagement - Prozesse und Vorgehensmodelle, Düsseldorf: Sypmposion, 2014, pp. 1-31. 
obvious is the use of agile processes in plant maintenance, sales and controlling. ${ }^{19}$

The following illustration (Figure 1) shows the order of the terms "Agile Value", "Agile Principal" and "Agile Method". It is important to notice that by starting with agile values, from invisible to the visible level and work with agile methods like Scrum, one of the agile methods. But to work effective in agile content it is needed to internalise the agile values and principles.

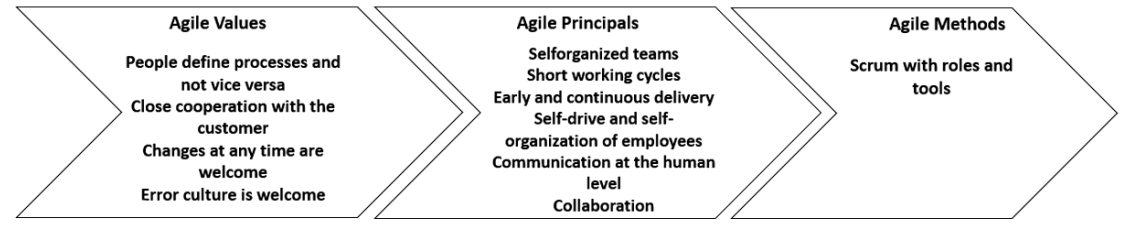

Figure 1. Agile scaling based on the existing characteristics in companies Source: Author's illustration

In summary it can be said that agility originates from the digital world and is understood in between as a cross-industry solution approach for a VUCA (V-volatility, U-uncertainty, C-complexity, A-ambiguity) environment. By transferring it to other application areas, agility has established itself as a management concept with a basic strategic understanding.

Agile companies work with a state that is both stable and flexible. Stability is created by frameworks for agile leadership, organisation, strategic goal setting and work. These enable the systematic, flexible handling of dynamic external requirements. Maximum adaptability with optimal stability is the declared maximum goal of agile enterprises.

Agility is not an end in itself - rather, it is about interacting more flexibly and at shorter intervals with the complex company environment. This interaction ultimately leads to better services and products for customers, and thus to market-changing offers. Rather, agility should increase the adaptability of the company and increase internal effectiveness and efficiency. Ideally, this is achieved by working agile and according to agile methods at all levels of the company.

\section{Agile approach versus classical approach}

Due to globalisation and internationalisation, the companies are facing pressures to be competitive in the market. The companies started to engage

${ }^{19}$ Rigby, D. K., Sutherland, J., \& Takeuchi, H.: Embracing Agile [Supplemental material]. Harvard Business Review. Retrieved from https://hbr.org/2016/05/embracing-agile, 2016. 
in project-based activities to solve this problem by reducing the uncertainty and to deliver product on time to the market ${ }^{20}$.This concept, in the context of an organisation, will allow to increase the flexibility, velocity, leanness, learning and response to change ${ }^{21}$.

Projects are formed to solve tasks that can be processed within the line. These are usually tasks that have to be processed only once or only rarely. When planning a project, the goals and the necessary resources are defined, and it is also crucial to create the framework conditions for the project organisation and the corresponding processes. Before a project can be started, the setting of objectives should be clear and the task should be defined, naturally adapted to the market requirements and the environment. Project management has the focus to follow the accomplishment of plans. The important and the main way is based on what is done on time and within budget. For this reason, tracing project plan is also the main task of project management.

According to Moran, agile project management is defines as "discipline that copes adaptively with rapid change through feedback learning loops that iteratively create and incrementally deliver value" 22 .

Agile project management approaches are becoming more common and popular in projects ${ }^{23}$, but it is not enterprise goal to reorganise the organisational structure. For this reason, there are existing hierarchical organisational structures und agile project structure side by side ${ }^{24}$. This leads to difficulties, as the structures strive for control and obedience rather than networking and communication. The challenge is to continue to promote agile projects despite the existing organisational structures and to bring them to a successful conclusion. The agile values and principles provide the framework for agile working. But they do not yet help to set up a concrete project management.

The continues improvement process is an important aspect. Because agility is a characteristic for a living system to meet constantly

${ }^{20}$ Raymond, L., \& Bergeron, F.: Project management information systems: An empirical study of their impact on project managers and project success. International Journal of Project Management, 26(2), 213-220. https://doi.org/10.1016/j.ijproman.2007.06.002; 2008.

${ }^{21}$ Campanelli, A. S., \& Parreiras, F. S.: Agile methods tailoring - A systematic literature review. Journal of Systems and Software, 110, 85-100, 2015, p. 86.

${ }^{22}$ Moran, A.: Agile Project Management. In: Managing Agile. Springer, Cham., 2015.

${ }^{23}$ Perlak, J.: Characteristics of self-organizing teams in agile project management: A case study, acta universitatis Nicolai copernici, 2019. p. 19-27.

${ }^{24}$ Lenges, M., Kloppenborg, T., Forte, F.: Identifying Key Agile Behaviors That Enhance Traditional Project Management Methodology, Journal of Strategic and Sustainability Vol. 13(2) 2018, p. 23. 
changing market conditions ${ }^{25}$. Organisation becomes a living organism. Characteristics of such lived agility are customer orientation and employee orientation, agility, ability to react and change and resilience ${ }^{26}$.

The use of highly qualified people brings not only technical, but also organisational psychological topics to projects, which are already considered and applied in the agile approach with the defined values and methods. The project manager, a generalist and team developer, can no longer give clear instructions in detail, but acts more as a coordinator of specialists and is responsible for cooperation and communication and hands over responsibilities for planning and ensuring factors to the people who work in the project. Instead of looking for errors in the employees or their qualifications, the agile approach looks at the environment and influencing factors and tries to install changes to the process and structure.

In agile project management, commitment to the team, the project object and the environment is a key success factor. The success and connection generally correlate with the attitude and the job satisfaction of the team members with whom he or she is compared to the project, the team and the environment ${ }^{27}$. Agile project management is based on empirical process and can by defined as a never-ending learning process ${ }^{28}$.

According to Sutherland and Ahmad traditional project management methods are noniterative, sequential, phased, and plan-driven ${ }^{29}$. But author like Joslin \& Müller assumes that it is hierarchical in structure in-addition to these characteristics. Furthermore, traditional project management theorists believe that it is a standardized process since a lot of planning is involved which makes it predictable ${ }^{30}$.

The waterfall method follows a clearly defined time frame, budget, scope which represents three dimensions of the iron triangle. The merits that are put forward for the waterfall model include its simplicity and ease of scheduling in laying out steps for development.

${ }^{25}$ Onag, G.: Agile project management goes beyond software development. Computerworld Hong Kong; Newton 2017, p. 1-3.

${ }^{26}$ Fernandez, D. J., \& Fernandez, J. D.: Agile project management - Agilism versus traditional approaches. Journal of Computer Information Systems, 49(2), 2008.

${ }^{27}$ El-Wakeel, F..: Further Demystification of agile Project Management, Technology Work Book, Strategy Finance/August 2019, p. 79.

${ }^{28}$ Measey, P.: Agile Foundations : Principles, Practices and Frameworks. (Radstad, Ed.). Swindon, SN2 1FA, UK: BCS Learning \& Development Ltd., 2015.

${ }^{29}$ Sutherland, J., \& Ahmad, N.: How a Traditional Project Manager Transforms to Scrum: PMBOK vs. Scrum, (Salt Lake City). https://34slpa7u66f159hfp1fhl9aur1-wpengine. netdna-ssl.com/wp-content/uploads/2014/05/PMBOK-vs.-Scrum-Agile2011.pdf, 2011.

${ }^{30}$ Joslin, R., \& Müller, R.: Relationships between a project management methodology and project success in different project governance contexts. International Journal of Project Management, 33(6), 1377-1392, 2015. 
Formal and informal networks come alongside the hierarchical organisational structure. The networks ensure faster decisions and flexible provision of resources, while the hierarchical structures ensure the necessary stability and implementation standards ${ }^{31}$.

Internal communication provides special communication platforms to promote quick coordination and decision-making within the framework of informal exchange relationship.

When putting together members of a group, the form of collaboration is still important when developing agile teams. Coagulating members conduct their activities relatively independently.

Agile project management is based on self-organised and self-learning teams or individuals. This requires a good network from each team member in the medium term, in which they can acquire and validate their required knowledge and information. In addition to the current situation and cultural influences, the actions of a team member also depend on the values they have and are correlated with each other ${ }^{32}$.

This type of teams will be characterised by having a fast decisionmaking process, high motivational levels due to the sense of autonomy and increased levels of initiative and continuous improvement ${ }^{33}$.

However, there are some factors that can demotivate team members, such as the increased level of stress for certain people due to the higher requirements in visibility and accountability, the continuous need to dedicate time to meetings, and the difficulty related to managing complex tasks in a short time frame.

For this reason, agile project management is being used more and more as it allows to adapt to a constantly changing world. The agile approach offers a flexible and less predictable approach. More and more companies that have developed their products using traditional waterfall methods are switching to agile practices.

In order to be able to react to the change in goals within a project by the client, technological progress or a lack of resources, classic and

${ }^{31}$ Knorre, S.: Interne Unternehmenskommunikation aus der Perspektive organisationaler Resilienz. In G. Bentele, M. Piwinger, \& G. Schönborn (Hrsg.), Kommunikationsmanagement. Strategien, Wissen, Lösungen (Loseblattsammlung, Lieferung 3.90). Neuwied: Luchterhand, 2012, pp. 7-8.

32 Tessem, B.: Individual empowerment of agile and non-agile software developers in small teams. Information and Software Technology, 56, 873-889, 2014.

${ }^{33}$ McHugh, O., Conboy, K., \& Lang, M.: Using Agile Practices to Influence Motivation within IT Project Teams. Scandinavian Journal of Information Systems, 23, 85-110, 2011, p. 98-100. 
planning-oriented project management often turned out to be too rigid and inflexible ${ }^{34}$.

In practice, classic project management models are used for projects that can be planned consistently and that are hardly variable over the course of the project. In the classic project management, the goal, time, and costs are important and those influencing factors can be clearly defined right from the start of the project. In addition, there is an important role in the implementation according to the waterfall model of management policy since the individual teams receive little personal responsibility ${ }^{35}$. Due to the detailed documentation of all phases, this model also favours projects with many external service providers and various interest groups, provided that these were sufficiently included in the development process right from the start in the planning and definition phase ${ }^{36}$.

In agile project management the entire project is not planned right from the start, but rather worked in stages that are characterised by a high degree of communication, adaptability and exchange. The project team undertakes the planning of these stages together and at the end of each stage there should be a result and the stage completed should be assessed in retrospective. This should lead to an increase in quality, acceleration of development time, focus on a result and a constant improvement of the process.

The following illustration (Figure 2) shows the different procedures for common classic and agile procedures.

In the waterfall model, the phases are predefined, and the next phase can only be started after the first phase has been completed. The form of classic project management is based on a linear sequence of individual project phases. This procedure is considered rigid and requires a long planning time. Documentation of the individual phases is particularly important, which ensures transparency of project progress and expenses.

Due to the linearity of the process, classic project management can be implemented in organisational structures with a hierarchical structure with little effort. The subdivision into individual, self-contained phases that do not allow any feedback to previous phases after completion is a special aspect.

${ }^{34}$ Onag, G.: Agile project management goes beyond software development. Computerworld Hong Kong; Newton 2017, p. 1-3.

${ }^{35}$ Lenges M., Kloppenborg T., Forte F: Identifying Key Agile Behaviors That Enhance Traditional Project Management Methodology., Journal of Strategic and Sustainability Vol. 13(2) 2018, p. 23.

${ }^{36}$ Wysocki, R.: Effective Project Management: Traditional, Agile, Extreme. Book (Vol. $7^{\text {th }}$ edition), 2014. 


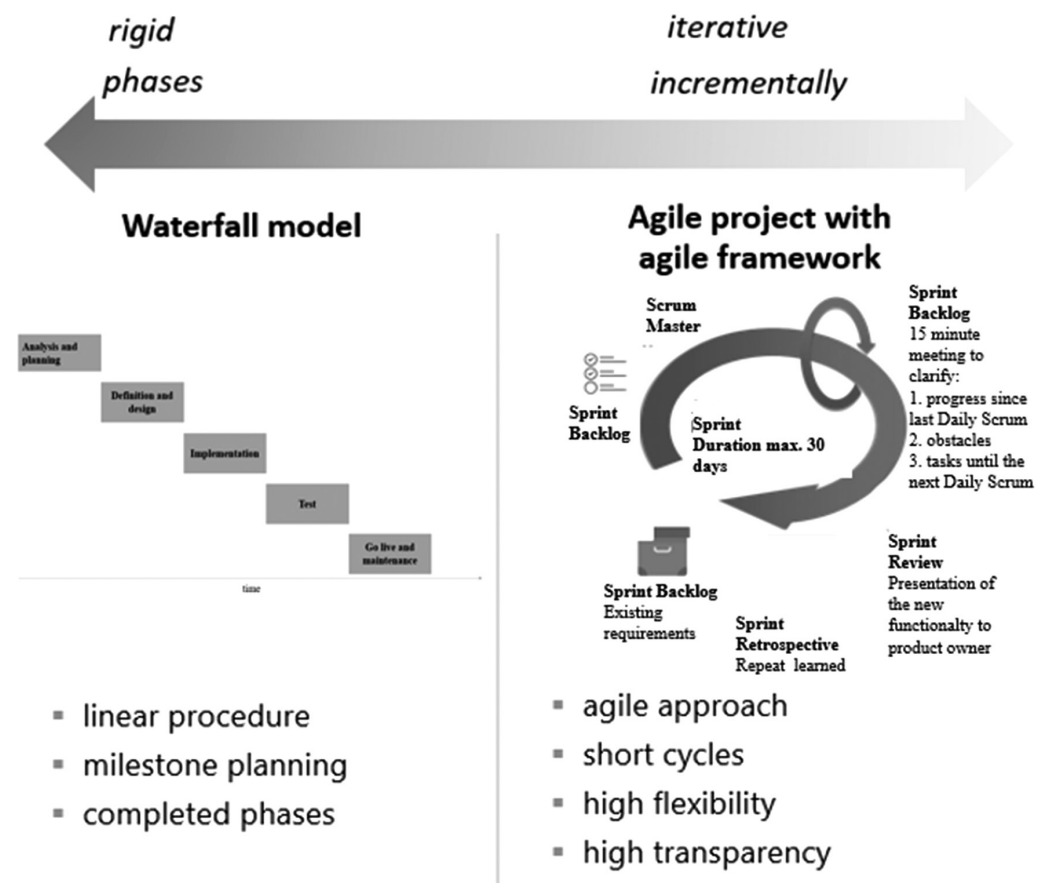

Figure 2. Structural Differences of the Waterfall model and Agile model. Source: Author's illustration

In contrast, the agile approach in projects is contradictory. Work is done in repetitive sprints, in short periods of time, and the result is built on the acquired knowledge ${ }^{37}$. With the agile model there are no rigid phases, but the different stages take place simultaneously and functional products are created and tested in several iterations.

Due to the increasing number of projects and the emergence of complexity, there is a growing need for transparency. The projects are partly in competition with each other. Several people in companies are only responsible for monitoring and control, so that the process is in accordance with the prescribed procedure.

Apart from the importance of project management in general, differentiation in size, uniqueness and complexity of projects put emphasis on the necessity of tailored management methods. Increasingly it is argued that nowadays a pure project management approach (the traditional

${ }^{37}$ El-Wakeel, F. A.: Further Demystification of agile Project Management, Technology Work Book, Strategy Finance/August 2019, p. 80. 
project management approach) is no longer effective ${ }^{38}$. Nevertheless, most of the current project management methodologies still seem to underestimate the influence of the dynamic environment.

\section{The Role of Leadership in the agile change}

Leadership and the agile change are strongly connected. Every change can be successfully integrated if the leadership in all levels enforce and support the agile change in the company. Leaders are able to establish a new agile mindset, work out strategic direction und support by implementation of agile methods in projects.

Leadership is a reciprocal, result-oriented, unstable object of giving and receiving, of expecting and fulfilling. These are always (micro) political processes, because "leadership" stands not just only for neutral psychosocial "soft facts" such as relationships, behaviours, feelings, motivation, climate, shared successes, but for interests, power, counter-power, dependencies, and sovereignty as well ${ }^{39}$.

In the leadership concept of leadership, organisations with a high need for change are assigned a leadership style that is endowed with a transformational characteristic. It is particularly appropriate in situations in which leaders cannot assess the work or solution approaches of their employees in detail, for example due to specialist knowledge or also in the context of quick decision-making.

According to Kotter effective manager is about giving employees an understanding of why a change process is necessary and what organisational benefits are derived from $\mathrm{it}^{40}$. So that everyone understands why certain processes are being carried out, just as complex as a change process. The change process is now a constant condition of companies, but employees do not understand the change and are therefore not behind it.

Studies by Jantz 2012, highlighted transformational leadership, which it was found to be more effective than laissez-faire or transactional leadership ${ }^{41,42}$.

${ }^{38}$ Hertogh, M., \& Westerveld, E: Playing with Complexity. Management and organisation of large infrastructural projects: AT Osborne/Transumo, 2010.

${ }^{39}$ Rieckmann, H.: Führungskraft und Management Development. München: GerlingAkad.-Verl, 2000.

${ }^{40}$ Kotter, J. P., \& Cohen, D. S.: The heart of change: real-life stories of how people change their organizations. Boston, MA: Harvard Business School Press, 2002.

${ }^{41}$ Castiglione, J.: Organizational learning and transformational leadership in the library environment. Library Management, 27(4/5), 289-299, 2006.

42 Jantz, R. C.: Innovation in academic libraries: An analysis of university librarians' perspectives. Library \& Information Science Research, 34(1), 3-12, 2012. 
Bass believes that the actions of transformational leaders focus more on organisational interests and put their own interests in the background. The transformative leader is respectful, confident, is clear in acting and thinking and also clearly communicates the goals. He or she involves employees and supports the innovation process or the willingness to try new things. This type of leader does not forget to support the learning and development process of the employee ${ }^{43}$.

According to Kouzes \& Posner 2012, the transformational leader achieves the highest level of performance and variation in the change process by interweaving the 4 levels ${ }^{44}$, by means of four dimensions:

1. Idealised influence

2. Inspirational motivation

3. Intellectual stimulation and

4. Individualised consideration

According to Mellor, leadership is characterised by trust and relies on the common achievement of the leader and the leader with a generally altruistic understanding of how to act. Leadership culture is going through a progressively rapid change.

This integrative understanding is already in the traditional concept of transformational leadership. It also requires leadership communication that is professionally designed from a strategic and operational point of view. In the context of agility, however, a new strong frame of reference for the consideration of leadership communication emerges as part of the expanded, transformational leadership style, which deals with the communication of "resilience".

Not only the transformational leader, but also the servant leader can lead the organisation and the team through the change process.

Overstreet et al. further explained that "elements of servant leadership theory and social exchange theory explain in what way developing organisational commitment via servant leadership behaviours can ultimately impact performance" 45

According to Greenleaf, "The servant-leader is servant first, it begins with the natural feeling that one wants to serve, to serve first. Then

${ }^{43}$ Bass, B. M.: From transactional to transformational leadership: Learning to share the vision. Organizational Dynamics, 18(3), 19-31, 1990.

${ }^{44}$ Yukl, G. A.: Leadership in organizations ( $8^{\text {th }}$ ed.). England: Pearson Education, Limited, 2013.

${ }^{45}$ Overstreet, R. E., Hazen, B. T., Skipper, J. B., \& Hanna, J. B.: Bridging the gap between strategy and performance: Using leadership style to enable structural elements. Journal of Business Logistics, 35 (2), 136-149, 2014, p. 136. 
conscious choice brings one to aspire to lead." ${ }^{46}$ The servant leader builds on trust and a commitment in an organisation. The servant leader aims to motivate employees and the servant leader also aims to develop employees. Above all, it is about personal and professional development as the exclusive achievement of his or her goals ${ }^{47}$.

The leadership theories that underlay the study also encompass theories of transformational leadership and servant leadership as important components of support in changing and shaping organisational culture.

The servant Leader offers a new approach to being a leader, one that is not classically seen in front. The servant leader is understood more as a servant who stands behind his or her employees, lets them be creative and let them free working spaces. The servant leader is increasingly appearing in the start-up culture and in the IT areas of traditional companies. Where creativity is increasingly required, it is controversial to think and act hierarchically and task-oriented. But it is precisely this leadership type that would be an opportunity for renewal in the big companies.

Companies educate and train their leaders to develop coaching skills and to have it like a leader's toolkit. But this mean that not every leader passes the adaptation of skills in the position. So, after the training it is a common way to fall to the common und usual command and control leadership way. So in summary the change process can 't happen really fast.

In order to be able to change it is necessary to inspire as a leadership employee and above all communication is crucial. To explain and communicate the goals, as well as the processes is crucial for changing culture.

It is important to give employees a certain amount of freedom and to promote self-organization. It is not always a smooth process to switch to self-organisation, where groups take ownership of their own decisions. Employees also need to be open to the type of change and see selforganisation as an advantage. Working according to instructions seems to be a better alternative because not every employee is ready for the type of change.

The following illustration (Figure 3) shows the rough structure of leadership influence and dependencies on the organizational performance.

${ }^{46}$ Greenleaf, R. K.: Servant Leadership: A journey into the nature of legitimate power and greatness. Mahwah, NJ: Paulist Press, 1977.

${ }^{47}$ Liden, E. C., Wayne S. Y., Thao H., Henderson D.: Servant Leadership: Development of a multidimensional measure and multilevel assessment. The Leadership Quarterly, Volume 19, Issue 2, 2008, p. 161-177. 


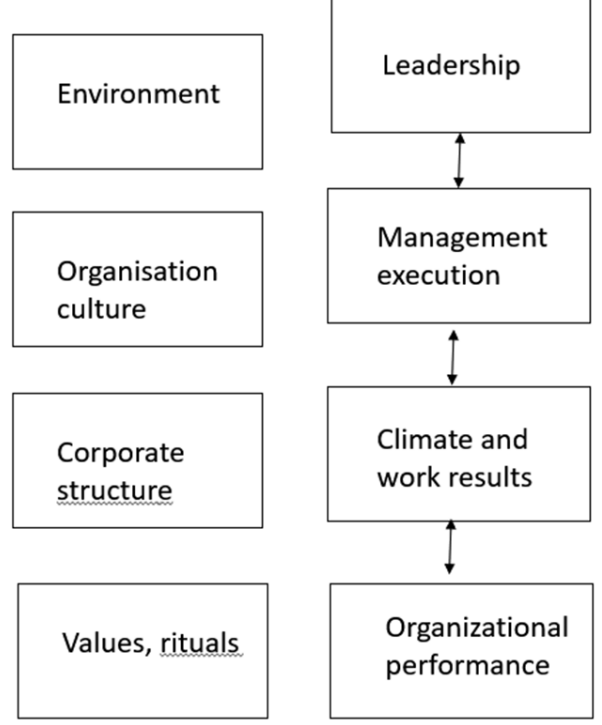

Figure 3. Leadership influence and dependencies on the organizational performance

Source: Author`s illustration

The above illustration shows that the levels are interrelated. The organisational performance depends very much on the results, which in turn are shaped and carried out by the leader.

The employees view the agile change process either positively or negatively. It depends on how leadership interaction works. If the employees understand what exactly happens in the change process and the complex change process brings an advantage to people and the organisation, then there is also the belief that the change process is necessary. In case of ignorance or not involving the employees there will be more resistance to the change process and disrupts organisational identity.

The following outline (Figure 4) shows the interdependency of the agile principle with leaders, culture and communication, employees and goals and visions of the company.

The illustration above shows how the agile principles interact with the following factors, such as employees, leaders, vision and aims and culture \& communication, and are interdependent to a certain extent. The elements are also dependent on each other and represent a kind of interaction. 


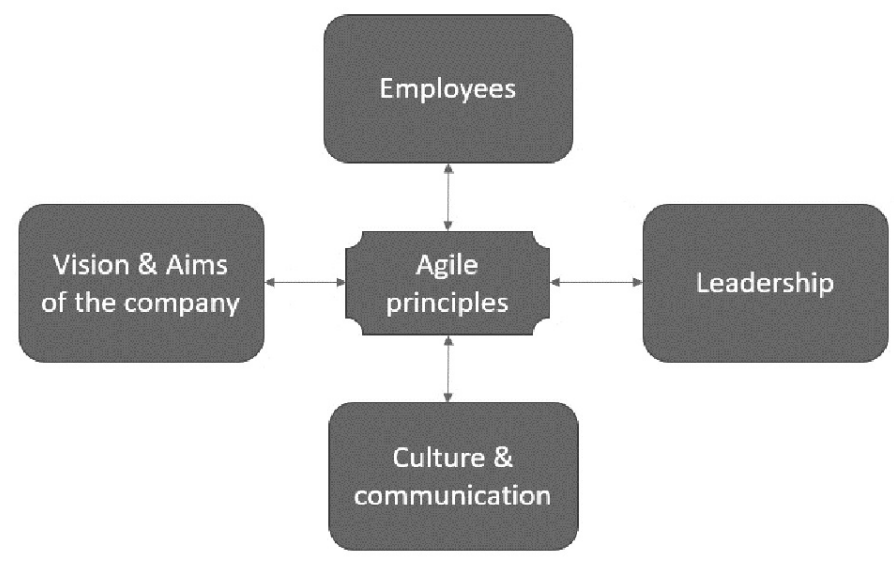

Figure 4. Interaction of the influencing corporate elements to create agile principles

Source: Author's illustration

It is a long and ongoing process until an agile way of thinking and working is reflected in companies. The results show that a stable framework inside the organization is crucial for this ${ }^{48}$.

Paradoxically, this leads to the fact that the basic rules and meaningful elements are ultimately subject to a negotiation process. That is, they themselves are to be regarded as contingent, but not to the extent that, for example, business strategic decisions are. The conscious acceptance, even the targeted use of paradoxes in leadership behaviour is generally seen as promoting agility ${ }^{49}$.

Planning is also key for team changes and employee development. In fact, employees need to be part of redefining quality of services and products, or companies will be unsuccessful in meeting change objectives. Accordingly, the basic elements of agile leadership are characterised on the one hand by a high degree of content-based and action-guiding basic rules - for all hierarchical and heterarchical organizational units. On the other hand, agile company management is based on independent, self-responsible action and collaboration among network members.

In a common change process, there are many ambiguities for the leadership especially at the beginning when no fundamental, systematic decisions

${ }^{48}$ Redmann, B.: Agiles Arbeiten im Unternehmen. Rechtliche Rahmenbedingungen und gesetzliche Anforderungen. Freiburg: Haufe, 2017, p. $34 \mathrm{ff}$.

${ }^{49}$ Lewis, M. W., Andriopoulos, C., \& Smith, W. K.: Paradoxical leadership to enable strategic agility. California Management Review, 2014, p. $63 \mathrm{f}$. 
or changes are in place and implementation are not yet mature. Leaders question how leadership should look like under these circumstances and try to transfer the changes into their praxis. Uncertainties and identity difficulties often arise.

\section{Conclusion}

Companies are in the age of changing market conditions and unpredictability due to rapid changes. The changing market conditions are currently being triggered by digital progress in order to tap to the new opportunities for a market change.

Today in companies, employee expect a leader who brings through the change and during this change generate a creative effect. The VUCA world probably has the greatest creative influence because predictability is hardly possible.

Agile change has visible and invisible processes that are in change. With agile adoption the change of company processes may be the most difficult.

The change process in companies aims to integrate the values or characteristics of agility into the company. The companies should therefore become more sensitive to signals from their environment and be able to react proactively and flexibly to them in the future. For this, however, not only teams and structures must be revised, but also the agile mindset and methods must be internalised.

Leadership has a strong influence on employee performance and thus ultimately on team performance. Especially in an agile working environment the implementation of good leadership is fundamental. The challenge: The leader's understanding of their role in an agile context changes completely. Up to now, management responsibilities have been centralised, but in an agile context, management responsibilities are distributed to other roles that did not exist in this form before. The responsibilities are shifted to where the expertise is to be find: to the employees. The focus is on the employee as a specialist. This change allows companies to do away with lengthy decision-making processes and coordination loops across several hierarchies and to achieve high flexibility and dynamic adaptation. However there is a determination about an ongoing process here.

In summary it is recommended to analyse and define the term agile for the company individually before planning und starting with implementation of agile methods. Changes can only be successfully implemented if employees and leaders are also willing to change. Changes, including the use of agile methods in the company, require the ability to learn - both on the part of employees and managers and on the part of the organisation. In this case, the leader must exemplify the willingness to change. 


\section{REFERENCES}

1. Alegría and Bastarrica (2006, pp. 5-10); Häusling, A., \& Wiegand, S. (2012, p. 19), Agil dank Scrum In Personalmagazin, 06, 18-20.

2. Bass, B. M. (1990): From transactional to transformational leadership: Learning to share the vision. Organizational Dynamics, 18(3), 19-31.

3. Campanelli, A. S., \& Parreiras, F. S.: Agile methods tailoring - A systematic literature review. Journal of Systems and Software, 110, 85-100. 2015.

4. Castiglione, J. (2006): Organizational learning and transformational leadership in the library environment. Library Management, 27(4/5), 289-299.

5. Greenleaf, R. K. (1977): Servant Leadership: A journey into the nature of legitimate power and greatness. Mahwah, NJ: Paulist Press.

6. Dingsøyr, T., \& Lassenius, C. (2012): Emerging themes in agile software development: Introduction to the special section on continuous value delivery. Information and Software Technology.

7. El-Wakeel F. (2019): Further Demystification of agile Project Management, Technology Work Book, Strategy Finance/August.

8. Erretkamps, H., \& Oswald, A. (2014): Der agile Produktentstehungsprozess - mehr als ein Prozess. In R. Wagner, \& N. Grau (Eds.), Basiswissen Projektmanagement Prozesse und Vorgehensmodelle, Düsseldorf: Sypmposion.

9. Fernandez, D. J., \& Fernandez, J. D. (2008): Agile project management - Agilism versus traditional approaches. Journal of Computer Information Systems, 49(2).

10. Förster, K., \& Wendler, R. (2012): Theorien und Konzepte zu Agilität in Organisationen. Dresdner Beiträge zur Wirtschaftsinformatik, 63(12)., 1.

11. Häusling, A., Rutz, B., Oimann, K., \& Oebbeke, B. (2014): Agil anpassen! Personalmagazin.

12. Hertogh, M., \& Westerveld, E (2010): Playing with Complexity. Management and organisation of large infrastructural projects: AT Osborne/Transumo.

13. Highsmith, J. A. (2004): Agile project management; creating innovative products; 1.Auflage; Addison-Wesley Longman; Amsterdam.

14. Jantz, R. C. (2012): Innovation in academic libraries: An analysis of university librarians' perspectives. Library \& Information Science Research, 34(1), 3-12.

15. Joslin, R., \& Müller, R. (2015): Relationships between a project management methodology and project success in different project governance contexts. International Journal of Project Management, 33(6), 1377-1392.

16. Kotter, J. P., \& Cohen, D. S. ( 2002): The heart of change: real-life stories of how people change their organizations. Boston, MA: Harvard Business School Press.

17. Knorre, S. (2012): Interne Unternehmenskommunikation aus der Perspektive organisationaler Resilienz. In G. Bentele, M. Piwinger, \& G. Schönborn (Hrsg.), Kommunikationsmanagement. Strategien, Wissen, Lösungen (Loseblattsammlung, Lieferung 3.90). Neuwied: Luchterhand.

18. Lenges M., Kloppenborg T., Forte F. (2018): Identifying Key Agile Behaviors That Enhance Traditional Project Management Methodology, Journal of Strategic and Sustainability Vol. 13(2). 
19. Lewis, M. W., Andriopoulos, C., \& Smith, W. K. (2014): Paradoxical leadership to enable strategic agility. California Management Review.

20. Liden, E. C., Wayne S. Y., Thao H., Henderson D. (2008): Servant Leadership: Development of a multidimensional measure and multilevel assessment. The Leadership Quarterly, Volume 19, Issue 2.

21. Onag G. (2017): Agile project management goes beyond software development. Computerworld Hong Kong; Newton.

22. Overstreet, R. E., Hazen, B. T., Skipper, J. B., \& Hanna, J. B. (2014): Bridging the gap between strategy and performance: Using leadership style to enable structural elements. Journal of Business Logistics, 35 (2), 136-149.

23. Perlak J. (2019): Characteristics of self-organizing teams in agile project management: A case study, acta universitatis Nicolai copernici.

24. McHugh, O., Conboy, K., \& Lang, M. (2011): Using Agile Practices to Influence Motivation within IT Project Teams. Scandinavian Journal of Information Systems, 23, 85-110.

25. Measey, P.: Agile Foundations (2015): Principles, Practices and Frameworks. (Radstad, Ed.). Swindon, SN2 1FA, UK: BCS Learning \& Development Ltd.

26. Mergel, I. (2016): Agile Innovation management in government: A research agenda. Government Information Quarterly, 33(3).

27. Miller, G. G. (2001): TOOLS '01 Proceedings of the $39^{\text {th }}$ International Conference and Exhibition on Technology of Object-Oriented Languages and Systems: The Characteristics of Agile Software Processes (pp. 385-387). Washington, DC.

28. Moran A. (2015): Agile Project Management. In: Managing Agile. Springer, Cham.

29. Raymond, L., \& Bergeron, F. (2008): Project management information systems: An empirical study of their impact on project managers and project success. International Journal of Project Management, 26(2), 213-220. https://doi. org/10.1016/j.ijproman.2007.06.002.

30. Redmann, B. (2017): Agiles Arbeiten im Unternehmen. Rechtliche Rahmenbedingungen und gesetzliche Anforderungen. Freiburg: Haufe.

31. Rigby, D. K., Sutherland, J., \& Takeuchi, H. (2016). Embracing Agile. Harvard Business Review.

32. Rieckmann, H. (2000): Führungskraft und Management Development. München: Gerling-Akad.-Verl,

33. Roghé F., Scholz S., Schudey A. (04/2017): Organisation im 21. Jahrhundert. Eine Studie identifiziert sechs Erfolgsfaktoren. Zeitschrift Führung und Organisation. www.wiso-net.de. (86. Jg.).

34. Siakas, K. V., \& Siakas, R. (2012): The Agile Professional Culture: A Source of Agile Quality. Software Process Improvement and Practice, 12.

35. Stoffel, M. 2016: Leadership 4.0 - Unternehmen brauchen ein neues "Betriebssystem”. In von C. Au (Ed.), Wirksame und nachhaltige Führungsansätze (pp. 205-222), Wiesbaden:Springer.

36. Sutherland Jeff, \& Ahmad Nafis. (2011): How a Traditional Project Manager Transforms to Scrum: PMBOK vs. Scrum, (Salt Lake City). https://34slpa7u66f159 hfp1fhl9aur1-wpengine.netdna-ssl.com/wp-content/uploads/2014/05/PMBOK-vs.Scrum-Agile2011.pdf. 
37. Termer F., Nissen V. (2014): Zum Begriff der Agilität - Betrachtungen und Implikation ausetymologischer Perspektive.

38. Tessem, B. (2014): Individual empowerment of agile and non-agile software developers in small teams. Information and Software Technology, 56, 873-889.

39. Williams, L., \& Cockburn, A. (2003): Agile Software Development: It's about Feedback and Change. Computer, 36(6), 39-43.

40. Wysocki, R. (2014): Effective Project Management: Traditional, Agile, Extreme. Book (Vol. $7^{\text {th }}$ editio).

41. Yukl, G. A. (2013): Leadership in organizations ( $8^{\text {th }}$ ed.). England: Pearson Education, Limited. 


\section{THE AUTHORS}

Inna Honcharuk is a PhD of Economics, Associate Professor, Vice-Rector for Scientific and Innovative Activities of Vinnitsa National Agrarian University (Ukraine). Scientific direction: economic efficiency of biofuel production; the use of biomass for the production of renewable energy sources to ensure the energy, economic and environmental security of the state.

Viesturs Pauls Karnups is a Dr. oec., Professor in international economic relations and economic history at the University of Latvia (LU), Business, Management and Economics Faculty, Department of Global Economics Interdisciplinary Studies, and Director of the LU North American Studies Centre. Senior Researcher at the LU Scientific Institute of Economics and Management. Was a Fulbright research scholar in 2008 at Georgetown University, Washington D.C., USA. Has published a large number of articles on Latvian economic history and international economics. Currently working on Latvian historical national accounts.

Sandra Jêkabsone, (Dr. oec., 2006, LU), is professor at the University of Latvia Faculty of Business, management and economics, Department of Economics, Economics Bachelor's and Master`s Programme director. Her main research directions is macroeconomics, national economy of Latvia, structural and investment policy, labour market, development of regional and social economy. She has participated in many research projects financed by The European Social Fund (ESF), Latvian Council of Science (LCS), University of Latvia (LU), including international cooperation projects. He has prepared more than 30 different publications (including internationally reviewed editions) and one monograph, as well as video lecture course "Practical macroeconomics".

Ilze Sproge, (Dr. sc. administr., 2011, LU), is associated professor at Transport and Telecommunication Institute, Acting Dean of the Faculty of Management and Economicsc and researcher at Institute for Mechanics of Materials at University of Latvia. Her previous research relates to national economy, the problems of financial management in enterprises, competitiveness and challenges of Latvia's economic development incl. tax change impact to national economy. She has a good experience in project management and independent scientific research and clearly understand the risks and ways to their reduction, she was a project leader in LatvianBelarus project "Economic and legal framework of international cooperation of Belarus and Latvia in the efficient use of mineral commodities". 
Solvita Kristone is a $\mathrm{PhD}$ student at the University of Latvia, Faculty of Business, management and economics and Executive director at Institute for Mechanics of Materials at University of Latvia.

Peeter Kenkmann obtained his MA in history in 2009. He is a PhD student at the University of Tartu, Institute of History and Archaeology, whose research topic is Estonian domestic politics in the 1930s - mainly the 1934 coup d'état, and the functioning of the resulting authoritarian regime (up to the occupation of Estonia by the Soviet Union in 1940).

Nurgul Janowski is a PhD student at the University of Latvia, Faculty of Business, management and economics. Currently, she is a project manager for digitization projects. The most projects are based on the manufacturing of trains, especially to digitalize the production steering processes with agile and lean methods. Nurgul Janowski had completed her university degree in Berlin at the Technical University in technical sociology and technical environment.

Ilze Medne, Dr. oec. is an associate professor at the University of Latvia, Faculty of Business, Management and Economics, lectures on tourism economics and marketing, business creation and development, has organised several studies on tourist consumer behaviour and satisfaction in Riga and Jūrmala, research on Latvia's travel destination in several European countries, Author of several scientific publications in the development of the Jūrmala Tourism Development Action Plan and development of recommendations for the new planning period of Latvian tourism policy in 2021-2027.

Kristīne Bērziņa, Mg.B.A. is a lecturer and researcher at the University of Latvia, Faculty of Business, Management and Economics, her research is related to tourism companies cooperation models, as well as traveller behaviour, practical experience has been gained since the 1990s working in tourism companies.

Aleksejs Jurša is a Mg. oec. For more than 8 years he worked in the Economic Analysis Department of the Ministry of Finance of the Republic of Latvia, where he performed the analysis of economic and financial processes taking place in Latvia and in the world. In 2012, he graduated from the International Economic Relations study program of the University of Latvia. In 2015, he graduated from the BA School of Business and Finance, where he obtained a master's degree in financial management and a qualification of a financial analyst. Fields on interest - macroeconomics, inflation, foreign direct investments, foreign trade. 

Humanities and Social Sciences: Latvia Volume 29, Issue 1 (Spring-Summer 2021)

University of Latvia Press 